\title{
Review of International Studies on Multiple Disabilities
}

\author{
Ayten DÜZKANTAR ${ }^{*}$ \\ Damla ALTIN ${ }^{* * *}$
}

\author{
Kürşat ÖĞÜLMÜŞs* \\ Bora GÖRGÜN ${ }^{* * * *}$
}

\begin{abstract}
The aim of this study is to review the international studies of multiple disabilities carried out and to give a point of view to new studies through evaluating the studies via an analysis of literature between 2010 and 2020 years. With that aim, scientific studies published over the last ten years in the world about children, their families, services and practices provided for them about multiple disabilities were reviewed. The criterion for determining the international articles examined was that they were published in refereed journals. The review was carried out at electronic databases. During reviewing, the databases of ERIC, EBSCO, Topic Search and Primary Search and international scientific journals were reviewed using the key words, special education, multiple disabilities, multiple impairments, severe and multiple disabilities between the years 2010-2020. Also, online indices were reached through the journals published in the related faculties of universities. 96 articles of the studies made in the world between 2010-2020 were examined. The articles reached were examined in terms of aim, participants, methods, limitations, findings, and suggestions, and they were explained detailedly in the findings part. It is hoped that the researches examined in this study will serve as a model for future studies about multiple inabilities and increase the scientific interest.
\end{abstract}

Keywords: Special education, multiple disabilities, severe multiple disabilities.

\footnotetext{
* Orcid ID: https://orcid.org/0000-0002-7590-8764, Assoc. Prof. Dr., Anadolu University, Research Institute for Individuals with Disablities, Turkey, auysal@anadolu.edu.tr

** Orcid ID: https://orcid.org/0000-0001-7551-6894, Assist. Prof. Dr., Kırıkkale University, Department of Speacial Education, Turkey, kursatogulmus@hotmail.com

*** Orcid ID: https://orcid.org/0000-0001-8091-7625, Res. Assist., Sakarya University, Department of Speacial Education, Turkey, altin@sakarya.edu.tr

**** Orcid ID: https://orcid.org/0000-0002-9080-5667, Assist. Prof. Dr., İzmir Demokrasi University, Department of Speacial Education, Turkey, bboorraagorgun@gmail.com
} 


\section{INTRODUCTION}

Multiple disability is an umbrella term involving the combination of various disabilities. Each disability generally increases the influence of each other, and causes more inabilities. Multiple disabled individuals have serious difficulties in living independently and require support forever because of the difficulties in motor skills, cognitive skills, social skills and self care skills (Orelove\&Sobsey, 1996).

While World Health Organization (WHO, 1997) defines multiple disability as having disabilities more than one and difficulties in learning, The Individuals with Disabilities Education Act (IDEA) (2004) defines from an educational point of view multiple disability as requiring advanced supportive education because of having various disabilities (mental inability + blindness, mental inability + orthopedic disabilities) and the inability to utilize the intitutions where special education programmes are implemented for a type of disability. The Individuals with Disabilities Education Act (IDEA) does not define severe disability in a separate category. It is stated that severe disability and multiple disability are connected concepts (Gargiulo, 2004 Quo. Bahçivanoğlu-Yazıcl, 2009).

It is commonly believed that the number of individuals with multiple disabilities is increasing both across the world and in our country. But the increase might be said to be related to becoming clearer of awareness and diagnosis. Another reason for the increase is the increasing rate of sustentation of premature or not healthy babies with the medical technology innovated. However, most of those babies have to live with one or more disability (Batu \& Kırcaali-İftar, 2005; Ayyıldız, 2007; Chaudhari, Otiv, Chitale, Pandit \& Hoge, 2003; Clark Gerken, 2004; Fazzi and Pogrund, Tra. Varol, 1996; Gresnight, 2007; Pawletco, 2002).

Prevalence of individuals with multiple inability is considered as $2 \%$ of individuals requiring special education (Meyen \& Skrtic, 1995). According to another reference evaluating in terms of the rate in the general population, severe and multiple inability is $1 \%$ of the individuals of normal population. About $40 \%$ of that percentage have additional inabilities (Hardin, 2006; Tam, Phillips \& Mudford, 2011).

The aim of this study is to review the studies of multiple disabilities and inabilities carried out in Turkey, and to give a point of view to new studies through evaluating the studies via an analysis of literature of last ten years. With that aim, answers to the following questions were searched: (i) What findings have been obtained recently from the studies about multiple disabilities and inabilities, (ii) with which aims, (iii) with which disability groups' subjects, (iv) through what methods more, (v) what difficulties were experienced in obtaining the findings, and (vi) what suggestions were made for the future studies?

\section{METHOD}

In the scope of the study, studies about the multiple disabilities and inabilities were examined via descriptive analysis through meta-synthesis. Meta-synthesis (a thematic content analysis), one of the qualitative research designs, was used in order to synthesize 
findings of the researches discussed in scope of this study (Çalık \& Sözbilir, 2014). In studies of meta-analysis, findings of the studies discussing the same theme in the determined areas of study are examined thematically, and interpreted instead of making implications. In studies of meta-analysis, effort is made to achieve perceivable and testable results (Walsh \& Downe, 2005).

\section{Determining the Researches}

In this study, studies made in the last 5 years about multiple disabilities and inabilities were evaluated. Three criteria were determined to choose the articles to include in the study: (a) children of the families consisting the study group and the participants in the study group been affected by multiple inabilities, (b) the studies been published between 2010-2020, (c) the articles been published in refereed journals. Articles included in the study were accessed to reviewing the electronic databases of ERIC, EBSCO, Topic Search and Primary Search, and theses in the The Council of Higher Education Thesis Center. These databases were preferred since they were the best-known and frequently used ones. In addition, they were accessed to in the journals published in online indices. During review, the key words "special education, multiple disabilities, multiple impairments, severe and multiple inabilities" between the determined years were used. As a result of reviewing, 96 articles were determined. Researches were examined considering the aim, subjects, environment, method, data collection tools used, and findings, and tabulated, and then explained detailedly in the findings part.

\section{Process of Descriptive Analysis}

Articles found through reviewing in accordance with the determined criteria were evaluated in terms of (a) aim of the study, (b) characteristics of participants, (c) method used, (d) limitations identified, (e) findings, and (f) suggestions. In addition, studies made were examined comparatively to provide a point of view for and to guide initiating new researches and practices about multiple disabilities and inabilities in our country.

Descriptive summaries of the study's purpose, subjects, environment, method, data collection tools and findings were made by two people, and the summaries of all articles were checked by the first author by comparatively. By creating sub-categories regarding the purpose, subjects, environment, method, data collection tools and findings of the studies, the consistency between categorizers was calculated and internal reliability of the study was conducted. In disagreements between categorizers, a consensus was achieved by looking again at the sub-categories together with the evaluator. The reliability calculation of the study was made using the formula "consensus / disagreement + consensus $x 100 " .100 \%$ regarding the aims of the studies; $95.7 \%$ regarding its subjects; $100 \%$ regarding the environment; $100 \%$ on method; Inter-categorizer reliability was determined as $91.4 \%$ for the data collection tools used and $95.7 \%$ for their findings. 


\section{FINDINGS}

Evaluations based on meta-analysis of the studies conducted about multiple disabilities and inabilities over the last ten years in the relevant literature were included, and effort was made to guide increasing tendency to new studies and maturing new ideas for new research. Aims, characteristics of participants, methods used, limitations, results and recommendations of the 96 articles (meeting the criteria determined during the literature review) were summarized below.

Research Findings by Aim: Categorization of 96articles examined by aim is illustrated in Table 1.

Table 1

Distribution of Articles by Aim

\begin{tabular}{|c|c|c|c|}
\hline Aim & Frequency & $\mathrm{N}$ & $\%$ \\
\hline $\begin{array}{l}\text { Teaching } \\
\text { communication and } \\
\text { attention skills }\end{array}$ & $\begin{array}{l}\text { Boas, Ferreira, Moura, Maia \& Amaral, 2016; Brug, Putten, } \\
\text { Penne, Maes \& Vlaskamp, 2016; Bullen, Luger, Prudhomme \& } \\
\text { Geiger, 2018; Delden, Wintels, Oorsouw, Evers, Embregts, } \\
\text { Heylen \& Reidsma, 2020; Felicio, Seabra-Junior \& Rodrigues, } \\
\text { 2019; Frederiks, Sterkenburg, Barakova \& Feijs, 2019; } \\
\text { Holmqvist, Derbring \& Wallin, 2017; Holyfield, 2019; Holyfield, } \\
\text { Brooks \& Schluterman, 2019; Johnson \& Parker, 2013; Kemp, } \\
\text { Stephenson, Cooper \& Hodge, 2016; Knapik-Szweda, 2019; } \\
\text { Kumar, 2013; Lancioni, Singh, O'Reilly, Sigafoos, Resta, } \\
\text { Campodonico Alberti \& Chiariello, 2020; Lancioni, Singh, } \\
\text { O’Reilly, Sigafoos, Boccasini, Perilli \& Spagnuolo, 2017; Lancioni, } \\
\text { Singh, O’Reilly, Sigafoos, D’Amico, Buonocunto, Navarro, } \\
\text { Lanzilotti \& Alberti, 2017; Lancioni, Singh, O’Reilly, Sigafoos, } \\
\text { Alberti, Perilli, Boccasini, Martire \& Zagaria, 2017; Lancioni, } \\
\text { Singh, O'Reilly, Green, Meer, Alberti, Perilli, Boccasini, Martire \& } \\
\text { Lang, 2015; Lancioni, Singh, O’Reilly, Sigafoos, Boccasini, } \\
\text { Martire \& Lang, 2014; Lancioni, Singh, O’Reilly, Sigafoos, Oliva, } \\
\text { Alberti \& Buono, 2014; Lancioni, Bellini, Oliva, Singh, O’Reilly, } \\
\text { Lang, Didden \& Bosco, 2011; Nijs, Vlaskamp \& Maes, 2020; } \\
\text { Pilesjö \& Norén, 2017; Ricci, Miglino, Alberti, Perilli \& Lancioni, } \\
\text { 2017. }\end{array}$ & 24 & 25 \\
\hline $\begin{array}{l}\text { Assessment and } \\
\text { improving of motor } \\
\text { skills }\end{array}$ & $\begin{array}{l}\text { Bossink, Putten, Waninge \& Vlaskamp, 2017; Cunha, Neiva \& } \\
\text { Silva, 2019; Ferreira, Zotz, Melo \& Israel, 2019; Lancioni, Singh, } \\
\text { O’Reilly, Sigafoos, Campodonico, Alberti, Perilli, Zimbaro, } \\
\text { Chiariello \& Campodonico, 2018; Lancioni, Singh, O’Reilly, } \\
\text { Sigafoos, Campodonico, Oliva, Alberti \& D’amico, 2018; Lancioni, } \\
\text { Singh, O’Reilly, Sigafoos, Alberti, Campodonico, Perilli, Chiariello } \\
\text { \& Zimbaro, 2017; Lancioni, Singh, O’Reilly, Sigafoos, Alberti, } \\
\text { Perilli, Zimbaro, Boccasini, Mazzola \& Russo, 2018; Lancioni, } \\
\text { Singh, O’Reilly, Sigafoos, Alberti, Perilli \& Campodonic, 2017; } \\
\text { Lancioni, Singh, O’Reilly, Sigafoos, Alberti \& Campodonico, 2016; } \\
\text { Lancioni, Singh, O'Reilly, Sigafoos, Oliva, Campodonico, Alberti \& } \\
\text { Lang, 2014; Lancioni, O’Reilly, Singh, Green, Oliva, } \\
\text { Campodonico, Lang \& Buono, 2013; Lancioni, O’Reilly, Singh, } \\
\text { Sigafoos, Oliva, Campodonico \& Lang, 2012; Shih, 2012; Neagu } \\
\text { and Zsuzsanna, 2020; Stasolla, Caffo, Perilli, Boccasini, Stella, } \\
\text { Damiani, Albano \& Damato, 2017; Wessels, Bossink \& Putten, } \\
\text { 2017. }\end{array}$ & 16 & 16.66 \\
\hline
\end{tabular}


Teaching the use of Argyropoulos \& Thymakis, 2014; Desideri, Bizzarri, Bitelli, technology

Roentgen, Gelderblom \& Witte, 2016; Holyfield, Light, Drager, McNaughton \& Gormley, 2018; Shih, 2014; Shih, 2013; Lancioni, Singh, O’Reilly, Sigafoos, Campodonico, Zimbaro, Alberti, Trubia \& Zagaria, 2018; Lancioni, O’Reilly, Sigafoos, Campodonico Perilli, Alberti, Ricci \& Miglino, 2017; Lancioni, Singh, O’Reilly, Sigafoos, Campodonico \& Alberti, 2017; Lancioni, O’Reilly, Singh Sigafoos, Boccasini, Martire, Perilli \& Spagnuolo, 2016; Lancioni, Singh, O’Reilly, Sigafoos, Boccasini, Martire \& Smaldone, 2016; Lancioni, O’Reilly, Singh, Green, Oliva, Buonocunto, Colonna \& Navarro, 2012; Lancioni, Singh, O'Reilly, Sigafoos, Oliva, Signorino \& Tommaso, 2010; Moir, 2010; Shih, 2011; Shih, Cheng, Li, Shih and Chiang, 2010; Shih, Shih \& Wang, 2010.

Teaching the daily Axelsson, Granlund \& Wilder, 2013; Benford, 2017; Eldeniz \& living skills

Bozak, 2020; Dayı and Safak, 2018; Hanzen, Nispen, Vlaskamp, Korevaar, Waninge \& Putten, 2020; Ivy, Hatton \& Wehby, 2018; Janssen, Brink-Groenendijk, Riksen-Walraven, Huisman, Dijk \& Ruijssenaars, 2014; Lancioni, Singh, O’Reilly, Sigafoos, Alberti, Chiariello \& Carrella, 2020; Lancioni, Singh, O’Reilly, Sigafoos, Alberti, Zimbaro \& Chiariello, 2017; Lancioni, Singh, O’Reilly, Sigafoos, Boccasini, Alberti \& Lang, 2014; Lancioni, Singh, O'Reilly, Sigafoos, Boccasini, Martire, Oliva \& Lang, 2014.

Coping with Bosch, Andringa, Peterson, Ruijssenaars \& Vlaskamp, 2017; challenging Desrochers, Oshlag \& Kennelly, 2014; Lancioni, Singh, O'Reilly, behaviour Green, Oliva \& Campodonico, 2013; Poppes, Putten \& Vlaskamp, 2014; Lancioni, O’Reilly, Singh, Sigafoos, Oliva, Alberti, Carrella, Didden \& Lang, 2013; Poppes, Putten, Frans, Brug \& Vlaskamp 2016, Sadler, 2019.

\begin{tabular}{|c|c|c|c|}
\hline $\begin{array}{l}\text { Teaching literacy/ } \\
\text { mathematics }\end{array}$ & $\begin{array}{l}\text { Holyfield, Caron, Light and McNaughton, 2019; Hudson, } \\
\text { Zambone and Brickhouse, 2016; Jongbloed-Pereboom, Peeters, } \\
\text { Overvelde, Sanden and Steenbergen, 2015; Ramani, Police and } \\
\text { Jacob, 2014; Wei, Blackorby and Schiller, 2011. }\end{array}$ & 5 & 5,20 \\
\hline $\begin{array}{l}\text { Preparation, } \\
\text { implementation } \\
\text { and adaption of } \\
\text { program }\end{array}$ & $\begin{array}{l}\text { Depountis, Okungu \& Molloy-Daugherty, 2019; Mechling \& } \\
\text { Bishop, 2011; Taylor \& Preece, } 2010 .\end{array}$ & 3 & 3.12 \\
\hline $\begin{array}{l}\text { Leisure time } \\
\text { activity }\end{array}$ & $\begin{array}{l}\text { Lancioni, Singh, O'Reilly, Sigafoos, Belardinelli, Buonocunto, } \\
\text { D’Amico, Navarro, Lanzilotti, Denitto, Tommaso \& Megna, 2015; } \\
\text { Lancioni, Singh, O’Reilly, Green, Oliva, Buonocunto, Sacco, } \\
\text { Biancardi \& Di Nuovo, 2012; Lancioni, O’Reilly, Singh, Sigafoos, } \\
\text { Alberti, Boccasini, Oliva \& Lang, 2014. }\end{array}$ & 3 & 3,12 \\
\hline $\begin{array}{l}\text { Determination of } \\
\text { opinions }\end{array}$ & Hostyn and Maes, 2013 & 2 & 2.08 \\
\hline $\begin{array}{l}\text { Self management } \\
\text { skills }\end{array}$ & $\begin{array}{l}\text { Shogren, Kennedy, Dowsett \& Little, 2014; Munde \& Vlaskamp, } \\
2014 .\end{array}$ & 2 & 2,08 \\
\hline Vocational training & Lancioni, Singh, O’Reilly, Green, Oliva \& Campodonico, 2013. & 1 & 1.04 \\
\hline Biological functions & Blain-Moraes \& Chau, 2012 & 1 & 1.04 \\
\hline $\begin{array}{l}\text { Assessment of } \\
\text { students/ } \\
\text { practitioners, } \\
\text { determination of } \\
\text { opinions }\end{array}$ & Krämer \& Zentel, 2020 & 1 & 1.04 \\
\hline $\begin{array}{l}\text { Teaching of } \\
\text { symbols }\end{array}$ & Trief, Cascella \& Bruce, 2013. & 1 & 1.04 \\
\hline $\begin{array}{l}\text { Teaching of } \\
\text { educational games }\end{array}$ & Ferreira, Travassos, Alves, Sampaio \& Pereira-Guizzo, 2013. & 1 & 1.04 \\
\hline
\end{tabular}




\begin{tabular}{llcc}
\hline $\begin{array}{l}\text { Assessment of } \\
\text { anxiety level }\end{array}$ & Nelson, Greenfield, Hyte \& Shaffer, 2013. & 1 & 1.04 \\
\hline $\begin{array}{l}\text { Response to } \\
\text { stimulus }\end{array}$ & Munde, Vlakamp, Maes \& Ruijssenaars, 2012. & 1 & 1.04 \\
\hline Toilet training & Chang, Lee, Chou, Chen \& Chen, 2011. & 1 & 1.04 \\
\hline
\end{tabular}

$25 \%$ of the studies were made to teach communication skills. Because of language development retardation, many individuals with multiple inabilities experience significant difficulties in communicating with people around (Akçamete, 1992; Chen, 2004; Hourcade, Pilotte, West \& Parette, 2004). Nakken and Vlaskamp (2007) stated that individuals with multiple inabilities had little or no verbal clarity, and almost no symbolic interaction.

$16 \%$ of the studies aimed to develop motor skills, in which technological support was also used. It was observed that feedbacks or reinforcements about the sufficiency of stimuli or the actions were made via technology. Individuals with multiple inabilities generally exhibit problems of physical and muscular development, of which primary ones are overcontraction or over-relaxation of children's muscles. Because of those characteristics of their big and small muscles, they have difficulty in daily basic functioning, and might not exhibit the developmental skills such as moving, sitting unsupported, standing, walking, moving hands and arms, holding, gripping, being nourished in a natural way (Kirk, Gallager, Anastasiow \& Coleman 2006; Petry \& Meas, 2007; Petitpierre, Wolf, Benz \& Adler, 2007; Şafak, 2012).

$11 \%$ of the studies are about teaching daily life skills. Individuals with multiple inabilities with severe physical problems are generally dependent on their caretakers for their daily care. The reason for it is that they need support for most of their independent life and self care activities (Bryant, Smith \& Bryant, 2008; Vlaskamp \& Putten, 2009; Hostyn, 2011). Sometimes they might need to be educated life long to learn each of the self care skills such as eating, dressing, undressing, brushing teeth, combing hair and toilet skills (Meyen \& Skrtic, 1995).

Five studies (5\%) aim to teach how to read and write. In a study, participants with multiple and severe inabilities were taught how to write using keyboards via technological support. Those studies were $4 \%$ of all, and teaching of leisure time activities were primarily focused on. Unless children with severe and multiple disabilities were taught systematically, they were not able to learn leisure time activities on their own (Tekin-İftar, 2005). Therefore, it should be considered an important aim and a part of their education to develop appropriate fun and leisure time activities for the severe and multiple disabled (Westling \& Fox, 2000). 
Research Findings by Participant: Categorization of the 96 articles by participants is illustrated in Table 2.

Table 2

\section{Distribution of Articles by Participant}

\begin{tabular}{lllll}
\hline Participants & Author & $\mathrm{N}$ & $\%$ \\
\hline Child with & Boas, Ferreira, Moura, Maia and Amaral, 2016; Bosch, & 40 & 42.55
\end{tabular}

multiple

disabilities
Boas, Ferreira, Moura, Maia and Amaral, 2016; Bosch,
Andringa, Peterson, Ruijssenaars and Vlaskamp, 2017; Bossink, Putten, Waninge and Vlaskamp, 2017; Brug, Putten, Penne, Maes and Vlaskamp, 2016; Bullen, Luger, Prudhomme and Geiger, 2018; Depountis, Okungu and Molloy-Daugherty, 2019; Desideri, Bizzarri, Bitelli, Roentgen, Gelderblom and Witte, 2016; Eldeniz and Bozak, 2020; Felicio, Seabra-Junior, Rodrigues, 2019; Holyfield, Light, Drager, McNaughton and Gormley, 2018; Holyfield, 2019; Holyfield, Brooks and Schluterman, 2019; Holyfield, Caron, Light and McNaughton, 2019; Hudson, Zambone and Brickhouse, 2016; Ivy, Hatton and Wehby, 2018; Knapik-Szweda, 2019; Lancioni, Singh, O'Reilly, Green, Meer, Alberti, Perilli, Boccasini, Martire and Lang, 2015; Lancioni, Singh, O’Reilly, Sigafoos, Belardinelli, Buonocunto, D'Amico, Navarro, Lanzilotti, Denitto, Tommaso and Megna, 2015; Shih, 2014; Janssen, Brink-Groenendijk, Riksen-Walraven, Huisman, Dijk and Ruijssenaars, 2014; Lancioni, Singh, O’Reilly, Sigafoos, Boccasini, Alberti and Lang, 2014; Shogren, Kennedy, Dowsett and Little, 2014; Lancioni, Singh, O'Reilly, Sigafoos, Oliva, Campodonico, Alberti and Lang, 2014; Lancioni, Singh, O’Reilly, Sigafoos, Boccasini, Martire and Lang, 2014; Lancioni, O'Reilly, Singh, Sigafoos, Alberti, Boccasini, Oliva and Lang, 2014; Hostyn and Maes, 2013; Shih, 2013; Lancioni, Singh, O’Reilly, Green, Oliva and Campodonico, 2013; Lancioni, O’Reilly, Singh, Sigafoos, Oliva, Alberti, Carrella, Didden and Lang, 2013; Lancioni, O’Reilly, Singh, Green, Oliva, Buonocunto, Colonna and Navarro, 2012; BlainMoraes and Chau, 2012; Lancioni, Singh, O’Reilly, Green, Oliva, Buonocunto, Sacco, Biancardi and Di Nuovo, 2012; Shih, 2011; Shih, 2012; Shih, Cheng, Li, Shih and Chiang, 2010; Lancioni, Singh, O'Reilly, Sigafoos, Oliva, Signorino and Tommaso, 2010; Shih, Shih and Wang, 2010; Neagu and Zsuzsanna, 2020; Pilesjö and Norén, 2017. Sadler, 2019; Stasolla, Caffo, Perilli, Boccasini, Stella, Damiani, Albano and Damato, 2017.

Adult with $\quad$ Benford, 2017; Cunha, Neiva and Silva, 2019; Delden, Wintels, multiple disabilities Oorsouw, Evers, Embregts, Heylen and Reidsma, 2020; Ferreira, Zotz, Melo and Israel 2019; Frederiks, Sterkenburg, Barakova, Feijs, 2019; Jongbloed-Pereboom, Peeters, Overvelde, Sanden and Steenbergen, 2015; Krämer and Zentel, 2020; Lancioni, Singh, O’Reilly, Sigafoos, Campodonico, Zimbaro, Alberti, Trubia and Zagaria, 2018; Lancioni, Singh, O’Reilly, Sigafoos, Alberti, Perilli, Zimbaro, Boccasini, Mazzola and Russo, 2018; Lancioni, Singh, O'Reilly, Sigafoos, Alberti, Chiariello and Carrella, 2020; Lancioni, Singh, O’Reilly, Sigafoos, Campodonico, Alberti, Perilli, Zimbaro, Chiariello and Campodonico, 2018; Lancioni, Singh, O'Reilly, Sigafoos, Boccasini, Perilli and Spagnuolo, 2017; Lancioni, Singh, O’Reilly, Sigafoos, Alberti, Campodonico, Perilli, Chiariello and Zimbaro, 2017; Lancioni, Singh, O’Reilly, Sigafoos, Alberti, 
Zimbaro and Chiariello, 2017; Lancioni, O’Reilly, Sigafoos, Campodonico Perilli, Alberti, Ricci and Miglino, 2017; Lancioni, Singh, O'Reilly, Sigafoos, Alberti, Perilli and Campodonic, 2017; Lancioni, Singh, O’Reilly, Sigafoos, Alberti, Perilli, Boccasini, Martire and Zagaria, 2017; Lancioni, Singh, O’Reilly, Sigafoos, D'Amico, Buonocunto, Navarro, Lanzilotti and Alberti, 2017; Lancioni, Singh, O'Reilly, Sigafoos, Campodonico and Alberti, 2017; Lancioni, Singh, O'Reilly, Sigafoos, Alberti and Campodonico, 2016; Lancioni, O'Reilly, Singh, Sigafoos, Boccasini, Martire, Perilli, Spagnuolo, 2016; Lancioni, Singh, O’Reilly, Sigafoos, Boccasini, Martire and Smaldone, 2016; Lancioni, O’Reilly, Singh, Green, Oliva, Campodonico, Lang and Buono, 2013; Poppes, Putten and Vlaskamp, 2014; Desrochers, Oshlag and Kennelly, 2014; Lancioni, Singh, O'Reilly, Sigafoos, Boccasini, Martire, Oliva and Lang, 2014; Argyropoulos and Thymakis, 2014; Munde and Vlaskamp, 2014; Trief, Cascella and Bruce, 2013; Johnson and Parker, 2013; Ferreira, Travassos, Alves, Sampaio and Pereira-Guizzo, 2013; Nelson, Greenfield, Hyte and Shaffer, 2013; Chang, Lee, Chou, Chen and Chen, 2011; Mechling and Bishop, 2011.

Mixed (Child and Dayı and Şafak, 2018; Holmqvist, Derbring and Wallin, 2017; Adult with Lancioni, Singh, O'Reilly, Sigafoos, Resta, Campodonico Alberti multiple and Chiariello, 2020; Lancioni, Singh, O’Reilly, Sigafoos, disabilities Campodonico, Oliva, Alberti and D'amico, 2018; Lancioni, Singh, O'Reilly, Sigafoos, Oliva, Alberti and Buono, 2014; Munde, Vlakamp, Maes and Ruijssenaars, 2012; Lancioni, O’Reilly, Singh, Sigafoos, Oliva, Campodonico and Lang, 2012; Ramani, Police and Jacob, 2014; Lancioni, Bellini, Oliva, Singh, O’Reilly, Lang, Didden and Bosco, 2011; Nijs, Vlaskamp and Maes, 2020; Ricci, Miglino, Alberti, Perilli and Lancioni, 2017; Taylor and Preece, 2010; Wei, Blackorby and Schiller, 2011; Wessels, Bossink and Putten, 2017.

\begin{tabular}{llll}
\hline $\begin{array}{l}\text { Early childhood } \\
\text { period }\end{array}$ & $\begin{array}{l}\text { Kemp, Stephenson, Cooper and Hodge, 2016; Kumar, 2013; } \\
\text { Moir, 2010. }\end{array}$ & 3.19 \\
\hline $\begin{array}{l}\text { Teacher/ } \\
\text { Therapist }\end{array}$ & $\begin{array}{l}\text { Hanzen, Nispen, Vlaskamp, Korevaar, Waninge and Putten, } \\
\text { 2020; Poppes, Putten, Frans, Brug and Vlaskamp, 2016; }\end{array}$ & 2.12 \\
\hline Parents & Axelsson, Granlund and Wilder, 2013. & 1 & 1.06
\end{tabular}

It is understood from the $54 \%$ of studies made with children that education studies were made in accordance with the principal of earliness before the inabilities due to the disabilities of individuals with multiple and severe inabilities turn into a handicap and become permanent. In some of the studies (14.5\%), it was observed that different ages of participants were taught same skills. It is noteworthy that not many studies were made for early childhood (6.25\%). It is in keeping with the number of individuals with multiple and severe inabilities in the population. It is known that the severe and multiple disabled are the $1 \%$ of the population (Hardin, 2006; Tam, Phillips \& Mudford, 2011).

It might be considered as the indicator of the recent years' increase in the support of education and therapy that the $30 \%$ of the studies were made for the adults with multiple and severe inabilities. Reason for it is that individuals with multiple inabilities are as $2 \%$ of the individuals requiring special education (Meyen and Skrtic, 1995). When it is 
thought that the number of individuals who were not educated at the upper age groups until education opportunities developed is bigger, it should be considered as a necessity that researches for them be more in number.

In terms of their proportion in the general population, it should be considered as a necessity to identify the needs and opinions of the individuals with severe and multiple inabilities and their primary caretakers.

Research Findings by Method: Categorization by method of the 96 articles examined is illustrated in Table 3. Single-Subject research models were preferred in most of the studies (68\%) examined. Abundance of the studies stems from that individuals with multiple and severe inabilities have very different characteristics and abilities, and that it is difficult to figure the group experimental studies. Moreover, it is because search of effective practices is also primarily considered in the form of functional studies.

Table 3

Distribution of Articles by Method

\begin{tabular}{|c|c|c|c|}
\hline Method & Author & $\mathrm{n}$ & $\%$ \\
\hline Single subject research & $\begin{array}{l}\text { Cunha, Neiva and Silva, 2019; Dayı and Şafak, 2018; } \\
\text { Delden, Wintels, Oorsouw, Evers, Embregts, Heylen and } \\
\text { Reidsma, 2020; Eldeniz and Bozak, 2020; Felicio, Seabra- } \\
\text { Junior, Rodrigues, 2019; Frederiks, Sterkenburg, Barakova, } \\
\text { Feijs, 2019; Holyfield, 2019; Holyfield, Brooks and } \\
\text { Schluterman, 2019; Holyfield, Caron, Light and } \\
\text { McNaughton, 2019; Hudson, Zambone and Brickhouse, } \\
\text { 2016; Ivy, Hatton and Wehby, 2018; Kemp, Stephenson, } \\
\text { Cooper and Hodge, 2016; Lancioni, Singh, O’Reilly, } \\
\text { Sigafoos, Campodonico, Zimbaro, Alberti, Trubia and } \\
\text { Zagaria, 2018; Lancioni, Singh, O’Reilly, Sigafoos, Alberti, } \\
\text { Chiariello and Carrella, 2020; Lancioni, Singh, O’Reilly, } \\
\text { Sigafoos, Resta, Campodonico Alberti and Chiariello, 2020; } \\
\text { Lancioni, Singh, O’Reilly, Sigafoos, Campodonico, Alberti, } \\
\text { Perilli, Zimbaro, Chiariello and Campodonico, 2018; } \\
\text { Lancioni, Singh, O’Reilly, Sigafoos, Campodonico, Oliva, } \\
\text { Alberti and D’amico, 2018; Lancioni, Singh, O’Reilly, } \\
\text { Sigafoos, Boccasini, Perilli and Spagnuolo, 2017; Lancioni, } \\
\text { Singh, O'Reilly, Sigafoos, Alberti, Campodonico, Perilli, } \\
\text { Chiariello and Zimbaro, 2017; Lancioni, Singh, O’Reilly, } \\
\text { Sigafoos, Alberti, Zimbaro and Chiariello, 2017; Lancioni, } \\
\text { Singh, O’Reilly, Sigafoos, D’Amico, Buonocunto, Navarro, } \\
\text { Lanzilotti and Alberti, 2017;Lancioni, Singh, O’Reilly, } \\
\text { Sigafoos, Alberti, Perilli and Campodonic, 2017; Lancioni, } \\
\text { O’Reilly, Sigafoos, Campodonico Perilli, Alberti, Ricci and } \\
\text { Miglino, 2017; Lancioni, Singh, O’Reilly, Sigafoos, } \\
\text { Campodonico and Alberti, 2017; Lancioni, Singh, O’Reilly, } \\
\text { Sigafoos, Alberti, Perilli, Boccasini, Martire and Zagaria, } \\
\text { 2017;Lancioni, Singh, O’Reilly, Sigafoos, Alberti and }\end{array}$ & 64 & 66.66 \\
\hline
\end{tabular}


Campodonico, 2016; Lancioni, O’Reilly, Singh, Sigafoos, Boccasini, Martire, Perilli, Spagnuolo, 2016; Lancioni, Singh, O'Reilly, Sigafoos, Boccasini, Martire and Smaldone, 2016; Lancioni, Singh, O’Reilly, Green, Meer, Alberti, Perilli, Boccasini, Martire and Lang, 2015; Lancioni, O’Reilly, Singh, Green, Oliva, Campodonico, Lang and Buono, 2013; Lancioni, Singh, O'Reilly, Sigafoos, Belardinelli, Buonocunto, D'Amico, Navarro, Lanzilotti, Denitto, Tommaso and Megna, 2015; Shih, 2014; Lancioni, Singh, O'Reilly, Sigafoos, Oliva, Alberti and Buono, 2014; Lancioni, Singh, O’Reilly, Sigafoos, Boccasini, Alberti and Lang, 2014; Desrochers, Oshlag and Kennelly, 2014; Lancioni, Singh, O'Reilly, Sigafoos, Oliva, Campodonico, Alberti and Lang, 2014; Lancioni, Singh, O'Reilly, Sigafoos, Boccasini, Martire, Oliva and Lang, 2014; Lancioni, Singh, O’Reilly, Sigafoos, Boccasini, Martire and Lang, 2014; Lancioni, O'Reilly, Singh, Sigafoos, Alberti, Boccasini, Oliva and Lang, 2014; Shih, 2013; Trief, Cascella and Bruce, 2013; Lancionı, Singh, O'Reilly, Green, Oliva and Campodonico, 2013; Lancioni, O’Reilly, Singh, Sigafoos, Oliva, Alberti, Carrella, Didden and Lang, 2013; Johnson and Parker, 2013; Nelson, Greenfield, Hyte and Shaffer, 2013; Shih, 2012; Lancioni, O'Reilly, Singh, Sigafoos, Oliva, Campodonico and Lang, 2012; Lancioni, O’Reilly, Singh, Green, Oliva, Buonocunto, Colonna and Navarro, 2012; Blain-Moraes and Chau, 2012; Ramani, Police and Jacob, 2014; Lancioni, Singh, O’Reilly, Green, Oliva, Buonocunto, Sacco, Biancardi and Di Nuovo, 2012; Lancioni, Bellini, Oliva, Singh, O’Reilly, Lang, Didden and Bosco, 2011; Chang, Lee, Chou, Chen and Chen, 2011; Mechling and Bishop, 2011; Shih, 2011; Shih, Cheng, Li, Shih and Chiang, 2010; Nijs, Vlaskamp and Maes, 2020; Taylor and Preece, 2010; Moir, 2010; Shih, Shih and Wang, 2010; Lancioni, Singh, O’Reilly, Sigafoos, Oliva, Signorino and Tommaso, 2010; Ricci, Miglino, Alberti, Perilli and Lancioni, 2017; Sadler, 2019; Stasolla, Caffo, Perilli, Boccasini, Stella, Damiani, Albano and Damato, 2017.

\begin{tabular}{l} 
Quantitative \\
and Vlaskamp, 2017; Bossink, Putten, Waninge and \\
Vlaskamp, 2017; Brug, Putten, Penne, Maes and Vlaskamp, \\
2016; Bullen, Luger, Prudhomme and Geiger, 2018; \\
Depountis, Okungu and Molloy-Daugherty, 2019; Desideri, \\
Bizzarri, Bitelli, Roentgen, Gelderblom and Witte, 2016; \\
Ferreira, Zotz, Melo and Israel 2019; Holyfield, Light, \\
Drager, McNaughton and Gormley, 2018; Krämer and \\
Zentel, 2020; Lancioni, Singh, O’Reilly, Sigafoos, Alberti, \\
Perilli, Zimbaro, Boccasini, Mazzola and Russo, 2018; \\
Jongbloed-Pereboom, Peeters, Overvelde, Sanden and \\
Steenbergen, 2015; Shogren, Kennedy, Dowsett and Little, \\
2014; Lancioni, Singh, O'Reilly, Sigafoos, Boccasini, \\
Martire, Oliva and Lang, 2014; Axelsson, Granlund and \\
Wilder, 2013; Neagu and Zsuzsanna, 2020; Poppes, Putten, \\
\hline
\end{tabular}


Frans, Brug and Vlaskamp, 2016; Wessels, Bossink and Putten, 2017.

\begin{tabular}{llc}
\hline Qualitative & Boas, Ferreira, Moura, Maia and Amaral, 2016; Ferreira, 9 & 9.37 \\
& Travassos, Alves, Sampaio and Pereira-Guizzo, 2013; & \\
& Hanzen, Nispen, Vlaskamp, Korevaar, Waninge and Putten, \\
& 2020; Holmqvist, Derbring and Wallin, 2017; Janssen, \\
& Brink-Groenendijk, Riksen-Walraven, Huisman, Dijk and \\
& Ruijssenaars, 2014; Munde, Vlakamp, Maes and \\
& Ruijssenaars, 2012; Munde and Vlaskamp, 2014; Pilesjö \\
& and Norén, 2017; Wei, Blackorby and Schiller, 2011. & \\
& Hostyn and Maes, 2013; Knapik-Szweda, 2019; Kumar, & 3 \\
& 2013. & 31 \\
\hline Case study & Poppes, Putten and Vlaskamp, 2014 & 1.04 \\
\hline Document analysis & Argyropoulos and Thymakis, 2014 & 1.04 \\
\hline Action research & & 1 \\
\hline
\end{tabular}

Quantitative feature of $12 \%$ of the studies reveals the presence of studies about the comparison and standardization of previous studies.

It requires the maintenance of Qualitative (10\%) studies that it is still a necessity to create a detailed and comprehensive accumulation of knowledge in the individuals with severe inabilities.

The fact that $4 \%$ of them are Case Studies and 2\% of them are Action Studies might be interpreted that search of solutions for very different individuals with severe inabilities was initiated. The fact that $2 \%$ of the studies are Document Analyses shows that it was being tried to design new and active practices based on the analysis of records related to the previous practices.

Research Findings by Limitation: Categorization by limitation of the 96 articles examined is illustrated in Table 4. No limitation was stated in about one fourth (27\%) of the studies examined.

Table 4

Distribution of Articles by Limitation

\begin{tabular}{llll}
\hline Limitation & Author & $\mathrm{n}$ & $\%$ \\
\hline Limitation about & Argyropoulos and Thymakis, 2014; Axelsson, Granlund and & 38 & 38.77 \\
participants & Wilder, 2013; Bosch, Andringa, Peterson, Ruijssenaars and & \\
& Vlaskamp, 2017; Bossink, Putten, Waninge and Vlaskamp, & \\
& 2017; Brug, Putten, Penne, Maes and Vlaskamp, 2016; & \\
& Desrochers, Oshlag and Kennelly, 2014; Depountis, Okungu & \\
and Molloy-Daugherty, 2019; Ferreira, Zotz, Melo and & \\
& Israel 2019; Holyfield, 2019; Holyfield, Brooks and & \\
& Schluterman, 2019; Holyfield, Caron, Light and & \\
& McNaughton, 2019; Hudson, Zambone and Brickhouse, & \\
& 2016; Johnson and Parker, 2013; Lancioni, Singh, O’Reilly, & \\
\hline
\end{tabular}


Sigafoos, Campodonico, Zimbaro, Alberti, Trubia and Zagaria, 2018; Lancioni, Singh, O’Reilly, Sigafoos, Boccasini, Perilli and Spagnuolo, 2017; Lancioni, Singh, O'Reilly, Sigafoos, Alberti, Chiariello and Carrella, 2020; Lancioni, Singh, O’Reilly, Sigafoos, Resta, Campodonico Alberti and Chiariello, 2020; Lancioni, Singh, O’Reilly, Sigafoos, Campodonico, Alberti, Perilli, Zimbaro, Chiariello and Campodonico, 2018; Lancioni, Singh, O’Reilly, Sigafoos, Campodonico, Oliva, Alberti and D'amico, 2018; Lancioni, Singh, O’Reilly, Sigafoos, Alberti, Campodonico, Perilli, Chiariello and Zimbaro, 2017; Lancioni, Singh, O’Reilly, Sigafoos, Alberti, Zimbaro and Chiariello, 2017; Lancioni, Singh, O'Reilly, Sigafoos, Alberti, Perilli and Campodonic, 2017; Lancioni, Singh, O'Reilly, Sigafoos, D'Amico, Buonocunto, Navarro, Lanzilotti and Alberti, 2017; Lancioni, O’Reilly, Sigafoos, Campodonico Perilli, Alberti, Ricci and Miglino, 2017; Lancioni, Singh, O’Reilly, Sigafoos, Campodonico and Alberti, 2017; Lancioni, Singh, O’Reilly, Sigafoos, Boccasini, Martire and Smaldone, 2016; Lancioni, Singh, O'Reilly, Green, Oliva and Campodonico, 2013; Lancioni, Singh, O'Reilly, Sigafoos, Oliva, Campodonico, Alberti and Lang, 2014; Lancioni, Singh, O'Reilly, Sigafoos, Boccasini, Martire and Lang, 2014; Lancioni, O'Reilly, Singh, Sigafoos, Alberti, Boccasini, Oliva and Lang, 2014; Lancioni, Singh, O’Reilly, Sigafoos, Boccasini, Alberti and Lang, 2014; Munde, Vlakamp, Maes and Ruijssenaars, 2012; Nelson, Greenfield, Hyte and Shaffer, 2013; Poppes, Putten and Vlaskamp, 2014; Ricci, Miglino, Alberti, Perilli and Lancioni, 2017; Stasolla, Caffo, Perilli, Boccasini, Stella, Damiani, Albano and Damato, 2017; Shih, 2013; Shih, 2014; Wei, Blackorb and Schiller, 2011.

Limitation about Axelsson, Granlund and Wilder, 2013; Hostyn and Maes,

implementation 2013; Boas, Ferreira, Moura, Maia and Amaral, 2016; Dayı and Şafak, 2018; Delden, Wintels, Oorsouw, Evers, Embregts, Heylen and Reidsma, 2020; Desideri, Bizzarri, Bitelli, Roentgen, Gelderblom and Witte, 2016; Eldeniz and Bozak, 2020; Frederiks, Sterkenburg, Barakova, Feijs, 2019; Hanzen, Nispen, Vlaskamp, Korevaar, Waninge and Putten, 2020; Holyfield, Light, Drager, McNaughton and Gormley, 2018; Ivy, Hatton and Wehby, 2018; Janssen, Brink-Groenendijk, Riksen-Walraven, Huisman, Dijk and Ruijssenaars, 2014; Kemp, Stephenson, Cooper and Hodge, 2016; Knapik-Szweda, 2019; Krämer and Zentel, 2020; Lancioni, Singh, O’Reilly, Sigafoos, Alberti, Perilli, Zimbaro, Boccasini, Mazzola and Russo, 2018; Lancioni, Singh, O’Reilly, Sigafoos, Alberti, Perilli, Boccasini, Martire and Zagaria, 2017; Lancioni, Singh, O’Reilly, Sigafoos, Alberti and Campodonico, 2016; Lancioni, O'Reilly, Singh, Sigafoos, Boccasini, Martire, Perilli, Spagnuolo, 2016; Nijs, Vlaskamp and Maes, 2020; Poppes, Putten, Frans, Brug and Vlaskamp, 2016; Shogren, Kennedy, Dowsett and Little, 2014; Lancioni, O'Reilly, Singh, Sigafoos, Oliva, Campodonico and Lang, 2012; Nelson, Greenfield, Hyte and Shaffer, 2013; Ramani, Police and Jacob, 2014; Moir, 2010; Sadler, 2019; Taylor and Preece, 2010; Wessels, Bossink and Putten, 2017.

Studies with not Benford, 2017; Blain-Moraes and Chau, 2012; Bullen, Luger, Prudhomme and Geiger, 2018; Cunha, Neiva and stated of limitation Silva, 2019; Felicio, Seabra-Junior, Rodrigues, 2019;

2929.59


Holmqvist, Derbring and Wallin, 2017; Neagu and Zsuzsanna, 2020; Lancioni, Singh, O’Reilly, Green, Meer, Alberti, Perilli, Boccasini, Martire and Lang, 2015; Lancioni, O’Reilly, Singh, Green, Oliva, Campodonico, Lang and Buono, 2013; Jongbloed-Pereboom, Peeters, Overvelde, Sanden and Steenbergen, 2015; Chang, Lee, Chou, Chen and Chen, 2011; Lancioni, Singh, O’Reilly, Sigafoos, Oliva, Alberti and Buono, 2014; Lancioni, Singh, O’Reilly, Sigafoos, Oliva, Shih, 2013; Kumar, 2013; Lancioni, O’Reilly, Singh, Sigafoos, Oliva, Alberti, Carrella, Didden and Lang, 2013; Lancioni, Singh, O’Reilly, Green, Oliva, Buonocunto, Sacco, Biancardi and Di Nuovo, 2012; Lancioni, O’Reilly, Singh, Green, Oliva, Buonocunto, Colonna and Navarro, 2012; Lancioni, Bellini, Oliva, Singh, O’Reilly, Lang, Didden and Bosco, 2011; Lancioni, Singh, O’Reilly, Sigafoos, Oliva, Signorino and Tommaso, 2010, Lancioni, Singh, O’Reilly, Sigafoos, Belardinelli, Buonocunto, D’Amico, Navarro, Lanzilotti, Denitto, Tommaso and Megna, 2015; Pilesjö and Norén, 2017; Shih, Shih and Wang, 2010.

\begin{tabular}{llcc}
\hline $\begin{array}{l}\text { Limitation about } \\
\text { instruments }\end{array}$ & $\begin{array}{l}\text { Shih, 2012; Mechling and Bishop, 2011; Shih, 2011; Shih, } \\
\text { Cheng, Li, Shih and Chiang, 2010. }\end{array}$ & 4 & 4.08 \\
\hline $\begin{array}{l}\text { Limitation about } \\
\text { stimuli }\end{array}$ & $\begin{array}{l}\text { Munde and Vlaskamp, 2014; Trief, Cascella and Bruce, } \\
\text { 2013; Munde, Vlakamp, Maes and Ruijssenaars, 2012. }\end{array}$ & 3 & 3.06 \\
\hline $\begin{array}{l}\text { Limitation about } \\
\text { environment }\end{array}$ & $\begin{array}{l}\text { Lancioni, Singh, O'Reilly, Sigafoos, Boccasini, Martire, Oliva } \\
\text { and Lang, 2014; Taylor and Preece, 2010. }\end{array}$ & 2 & 2.04 \\
\hline $\begin{array}{l}\text { Limitation about } \\
\text { baseline }\end{array}$ & $\begin{array}{l}\text { Ferreira, Travassos, Alves, Sampaio and Pereira-Guizzo, } \\
\text { 2013. }\end{array}$ & \multirow{2}{*}{1} & \\
\hline
\end{tabular}

Limitation about the participants was stated in $29 \%$ of the studies. More than half of the limitations about the participants are about the scarcity of subjects. Scarcity of subjects in single-subject studies is an acceptable limitation. Because single-subject researches are among semi-experimental studies, the generalizability of the findings is aimed through repeated studies. Another limitation about the participants is lack of neutral assignment, and is about the subject selection.

Another limitation is about the implementation (24\%). Researchers list the implementation limitations as implementing for a single behavior, collecting studies based on analysis from limited data, ignoring participants' reactions, low ability of caretakers to implement, inconstant and poorly prepared implementation environment. Mentioned limitations are seen at a level to influence the reliability of implementation. It is thought that the studies were made in the implementation environments, and that education and therapy practices were tried to be made in the study format.

Research Findings by Result: Categorization by result of the 48 articles is illustrated in Table 5. It was found that technology-aided implementations used in $69 \%$ of the studies examined were effective in teaching the multiple disabled individuals different skills. 
Table 5

Distribution of Articles by Result

\begin{tabular}{l}
\hline Results \\
\hline Efficient studies \\
that providing \\
skills and changing \\
behaviour via \\
technology \\
support
\end{tabular}

\begin{tabular}{lll} 
Author & $\mathrm{n}$ & $\%$ \\
\hline Benford, 2017; Bossink, Putten, Waninge and Vlaskamp, & 65 & 69.14 \\
2017; Bullen, Luger, Prudhomme and Geiger, 2018; & &
\end{tabular}
Cunha, Neiva and Silva, 2019; Dayı and Şafak, 2018; Delden, Wintels, Oorsouw, Evers, Embregts, Heylen and Reidsma, 2020; Desideri, Bizzarri, Bitelli, Roentgen, Gelderblom and Witte, 2016; Eldeniz and Bozak, 2020; Frederiks, Sterkenburg, Barakova, Feijs, 2019; Holyfield, Light, Drager, McNaughton and Gormley, 2018; Holyfield, 2019; Holyfield, Brooks and Schluterman, 2019; Hudson, Zambone and Brickhouse, 2016; Ivy, Hatton and Wehby, 2018; Kemp, Stephenson, Cooper and Hodge, 2016; Knapik-Szweda, 2019; Lancioni, Singh, O’Reilly, Sigafoos, Alberti, Chiariello and Carrella, 2020; Lancioni, Singh, O’Reilly, Sigafoos, Campodonico, Alberti, Perilli, Zimbaro, Chiariello and Campodonico, 2018; Lancioni, Singh, O'Reilly, Sigafoos, Campodonico, Oliva, Alberti and D'amico, 2018; Lancioni, Singh, O'Reilly, Sigafoos, Campodonico, Zimbaro, Alberti, Trubia and Zagaria, 2018; Lancioni, Singh, O’Reilly, Sigafoos, Alberti, Perilli, Zimbaro, Boccasini, Mazzola and Russo, 2018; Lancioni, Singh, O’Reilly, Sigafoos, Alberti, Campodonico, Perilli, Chiariello and Zimbaro, 2017; Lancioni, Singh, O'Reilly, Sigafoos, Alberti, Zimbaro and Chiariello, 2017; Lancioni, Singh, O'Reilly, Sigafoos, Alberti, Perilli and Campodonic, 2017; Lancioni, Singh, O'Reilly, Sigafoos, D'Amico, Buonocunto, Navarro, Lanzilotti and Alberti, 2017; Lancioni, O’Reilly, Sigafoos, Campodonico Perilli, Alberti, Ricci and Miglino, 2017; Lancioni, Singh, O'Reilly, Sigafoos, Campodonico and Alberti, 2017; Lancioni, Singh, O'Reilly, Sigafoos, Alberti, Perilli, Boccasini, Martire and Zagaria, 2017; Lancioni, Singh, O’Reilly, Sigafoos, Alberti and Campodonico, 2016; Lancioni, O’Reilly, Singh, Sigafoos, Boccasini, Martire, Perilli, Spagnuolo, 2016; Lancioni, Singh, O'Reilly, Sigafoos, Boccasini, Martire and Smaldone, 2016; Lancioni, Singh, O’Reilly, Green, Meer, Alberti, Perilli, Boccasini, Martire and Lang, 2015; Munde and Vlaskamp, 2014; Lancioni, O’Reilly, Singh, Green, Oliva, Campodonico, Lang and Buono, 2013; Lancioni, Singh, O’Reilly, Sigafoos, Belardinelli, Buonocunto, D’Amico, Navarro, Lanzilotti, Denitto, Tommaso and Megna, 2015; Shih, 2014; Lancioni, Singh, O'Reilly, Sigafoos, Oliva, Alberti and Buono, 2014; Lancioni, Singh, O'Reilly, Sigafoos, Boccasini, Alberti and Lang, 2014; Lancioni, Singh, O’Reilly, Sigafoos, Oliva, Campodonico, Alberti and Lang, 2014; Lancioni, Singh, O'Reilly, Sigafoos, Boccasini, Martire, Oliva and Lang, 2014; Lancioni, Singh, O'Reilly, Sigafoos, Boccasini, Martire and Lang, 2014; Lancioni, O’Reilly, Singh, Sigafoos, Alberti, Boccasini, Oliva and Lang, 2014; Argyropoulos and Thymakis, 2014; Shih, 2013; Lancioni, Singh, O’Reilly, Green, Oliva and Campodonico, 2013; Lancioni, O’Reilly, Singh, Sigafoos, Oliva, Alberti, Carrella, Didden and Lang, 2013; Neagu and Zsuzsanna, 2020; Pilesjö and Norén, 2017; Ferreira, Travassos, Alves, Sampaio and Pereira-Guizzo, 2013; 
Nelson, Greenfield, Hyte and Shaffer, 2013; Shih, 2012; Munde, Vlakamp, Maes and Ruijssenaars, 2012; Lancioni, O'Reilly, Singh, Sigafoos, Oliva, Campodonico and Lang, 2012; Lancioni, O’Reilly, Singh, Green, Oliva, Buonocunto, Colonna and Navarro, 2012; Blain-Moraes and Chau, 2012; Lancioni, Singh, O’Reilly, Green, Oliva, Buonocunto, Sacco, Biancardi and Di Nuovo, 2012; Lancioni, Bellini, Oliva, Singh, O’Reilly, Lang, Didden and Bosco, 2011; Chang, Lee, Chou, Chen and Chen, 2011; Mechling and Bishop, 2011; Shih, 2011; Shih, Cheng, Li, Shih and Chiang, 2010; Lancioni, Singh, O’Reilly, Sigafoos, Oliva, Signorino and Tommaso, 2010; Shih, Shih and Wang, 2010; Ricci, Miglino, Alberti, Perilli and Lancioni, 2017; Stasolla, Caffo, Perilli, Boccasini, Stella, Damiani, Albano and Damato, 2017.

Efficient studies that providing interaction and communication
Boas, Ferreira, Moura, Maia and Amaral, 2016; Brug, Putten, Penne, Maes and Vlaskamp, 2016; Felicio, SeabraJunior, Rodrigues, 2019; Hanzen, Nispen, Vlaskamp, Korevaar, Waninge and Putten, 2020; Lancioni, Singh, O'Reilly, Sigafoos, Resta, Campodonico Alberti and Chiariello, 2020; Lancioni, Singh, O’Reilly, Sigafoos, Boccasini, Perilli and Spagnuolo, 2017; Nijs, Vlaskamp and Maes, 2020;

Hostyn and Maes, 2013; Kumar, 2013; Johnson and Parker, 2013; Taylor and Preece, 2010.

Devoloping assessment tool studies

Depountis, Okungu and Molloy-Daugherty, 2019; Ferreira, Zotz, Melo and Israel 2019; Holmqvist, Derbring and Wallin, 2017; Janssen, Brink-Groenendijk, RiksenWalraven, Huisman, Dijk and Ruijssenaars, 2014; Krämer and Zentel, 2020; Shogren, Kennedy, Dowsett and Little, 2014; Wei, Blackorby and Schiller, 2011.

\begin{tabular}{|c|c|c|c|}
\hline $\begin{array}{l}\text { Efficient studies } \\
\text { that reduction of } \\
\text { problem behaviour }\end{array}$ & $\begin{array}{l}\text { Bosch, Andringa, Peterson, Ruijssenaars and Vlaskamp, } \\
\text { 2017; Desrochers, Oshlag and Kennelly, 2014; Poppes, } \\
\text { Putten and Vlaskamp, 2014; Poppes, Putten, Frans, Brug } \\
\text { and Vlaskamp, 2016; Sadler, } 2019 .\end{array}$ & 5 & 5.31 \\
\hline $\begin{array}{l}\text { Efficient studies } \\
\text { that provide } \\
\text { academic skills }\end{array}$ & $\begin{array}{l}\text { Holyfield, Caron, Light and McNaughton, 2019; } \\
\text { Jongbloed-Pereboom, Peeters, Overvelde, Sanden and } \\
\text { Steenbergen, 2015; Poppes, Putten and Vlaskamp, 2014; } \\
\text { Ramani, Police and Jacob, 2014. }\end{array}$ & 4 & 4.25 \\
\hline $\begin{array}{l}\text { Study which is } \\
\text { reported that } \\
\text { ineffectiveness } \\
\text { about symbol } \\
\text { reinforcement }\end{array}$ & Trief, Cascella and Bruce, 2013 & 1 & 1.06 \\
\hline $\begin{array}{l}\text { Studies which } \\
\text { expected effect } \\
\text { was not found }\end{array}$ & Wessels, Bossink and Putten, 2017. & 1 & 1.06 \\
\hline
\end{tabular}

When the studies are examined, it is seen that the technology-aided practices consisted of equipment such as programmes designed or organized specially by the research team, sensors, micro keys, special softwares, computers, phones and videos. It is seen that many different skills were studied via the technology-aided practices. When the studies are examined, it is seen that technology-aided practices were made use of in teaching using bodily reactions, doing exercises and communicational behaviors such as typing messages on the phone, smiling, calling the caretaker; computer skills such as marking, typing, using 
a mouse; self-management skills such as selecting daily routines and obeying them, doing the jobs given and adaptive behaviors.

It is observed that the technologic adaptations in some of the studies were reproduced through adapting the constructs of present technologic hardware. However, because the other technologic supports were not at the advanced level use of technology, they were reported to be easily created and implemented. For example, micro keys and minimal sensors are today used as technologic devices in many places. It is quite functional to use them to design a system in the bed of the individual with multiple and severe inabilities to express communications with the caretakers and wishes (8\%).

Studies made to evaluate the individuals with multiple and severe inabilities (6\%) are very important in that their educational needs can be identified, and arrangements and programming can be created to meet their educational needs. Today negative effects of the uncertainty in identifying and evaluating the individuals with multiple and severe inabilities, creating their educational settings and programmes are all known (Turnbull, Turnbull, Shank, Smith and Leal, 2002).

When the studies in which the implementations were ineffective are examined, one study was identified to have had problems with the implementation process (Trief, Cascella and Bruce, 2013). Another study by Shogren, Kennedy, DowSett and Little (2014) is about the adaptation of the measurement tool. In this study, it was stated that it caused problems that the four sub-scales of the Wehmeyer and L. Kelchner (1995) Self-Management Scale were used as they were.

Research Findings by Suggestion: Categorization by method of the 96 articles examined is illustrated in Table 6.

Table 6.

Distribution of Articles by Suggestion

\begin{tabular}{llc}
\hline Suggestions & Author & $\mathrm{n}$ \\
\hline $\begin{array}{l}\text { Studies that suggest to } \\
\text { be repeated by }\end{array}$ & Benford, 2017; Bossink, Putten, Waninge \& Vlaskamp, & 39 \\
systimizing and & 2017; Dayı \& Şafak, 2018; Delden, Wintels, Oorsouw, & 33.05 \\
developing the & Evers, Embregts, Heylen \& Reidsma, 2020; Eldeniz \& & \\
practice of study & Bozak, 2020; Frederiks, Sterkenburg, Barakova \& Feijs, \\
& 2019; Holmqvist, Derbring \& Wallin, 2017; Holyfield, \\
& Light, Drager, McNaughton and Gormley, 2018; \\
& Holyfield, 2019; Holyfield, Brooks \& Schluterman, \\
& 2019; Holyfield, Caron, Light \& McNaughton, 2019; \\
& Hudson, Zambone and Brickhouse, 2016; Ivy, Hatton \& \\
& Wehby, 2018; Jongbloed-Pereboom, Peeters, \\
& Oandrvelde, Sanden \& Steenbergen, 2015; Knapik- & \\
Szweda, 2019; Krämer \& Zentel, 2020; Lancioni, Singh, \\
O'Reilly, Sigafoos, Alberti, Chiariello \& Carrella, 2020; \\
Lancioni, Singh, O'Reilly, Sigafoos, Resta, Campodonico \\
Alberti \& Chiariello, 2020; Lancioni, Singh, O’Reilly, \\
Sigafoos, Campodonico, Oliva, Alberti \& D'amico, 2018; \\
Lancioni, Singh, O’Reilly, Sigafoos, Alberti, Perilli, \\
\hline
\end{tabular}


Zimbaro, Boccasini, Mazzola and Russo, 2018; Lancioni, Singh, O’Reilly, Sigafoos, Boccasini, Perilli \& Spagnuolo, 2017; Lancioni, Singh, O'Reilly, Sigafoos, Alberti, Zimbaro \& Chiariello, 2017; Lancioni, O’Reilly, Sigafoos, Campodonico Perilli, Alberti, Ricci \& Miglino, 2017; Lancioni, Singh, O’Reilly, Sigafoos, Alberti, Perilli \& Campodonic, 2017; Lancioni, Singh, O’Reilly, Sigafoos, Alberti, Perilli, Boccasini, Martire \& Zagaria, 2017; Lancioni, Singh, O'Reilly, Sigafoos, Boccasini, Martire \& Smaldone, 2016; Neagu \& Zsuzsanna, 2020; Nijs, Vlaskamp \& Maes, 2020; Poppes, Putten \& Vlaskamp, 2014; Desrochers, Oshlag \& Kennelly, 2014; Shogren, Kennedy, Dowsett \& Little, 2014; Hostyn \& Maes, 2013; Janssen, Brink-Groenendijk, Riksen-Walraandn, Huisman, Dijk \& Ruijssenaars, 2014; Johnson \& Parker, 2013; Ferreira, Travassos, Alves, Sampaio \& PereiraGuizzo, 2013; Chang, Lee, Chou, Chen \& Chen, 2011; Lancioni, Singh, O’Reilly, Sigafoos, Oliva, Signorino \& Tommaso, 2010; Pilesjö \& Norén, 2017; Wessels, Bossink \& Putten, 2017.

Studies that repitation Boas, Ferreira, Moura, Maia \& Amaral, 2016; Brug, Putten, Penne, Maes \& Vlaskamp, 2016; Cunha, Neiva \& Silva, 2019; Desideri, Bizzarri, Bitelli, Roentgen, Gelderblom \& Witte, 2016; Felicio, Seabra-Junior \& Rodrigues, 2019; Ferreira, Zotz, Melo \& Israel 2019; Hanzen, Nispen, Vlaskamp, Korevaar, Waninge \& Putten, 2020; Jongbloed-Pereboom, Peeters, Overvelde, Sanden \& Steenbergen, 2015; Kemp, Stephenson, Cooper \& Hodge, 2016; Lancioni, Singh, O’Reilly, Sigafoos, Campodonico, Alberti, Perilli, Zimbaro, Chiariello \& Campodonico, 2018; Lancioni, Singh, O'Reilly, Sigafoos, Campodonico, Zimbaro, Alberti, Trubia \& Zagaria, 2018;Lancioni, Singh, O’Reilly, Sigafoos, Alberti, Campodonico, Perilli, Chiariello \& Zimbaro, 2017; Lancioni, Singh, O’Reilly, Sigafoos, Campodonico \& Alberti, 2017; Lancioni, Singh, O’Reilly, Sigafoos, Belardinelli, Buonocunto, D’Amico, Navarro, Lanzilotti, Denitto, Tommaso \& Megna, 2015; Lancioni, Singh, O’Reilly, Green, Meer, Alberti, Perilli, Boccasini, Martire \& Lang, 2015; Shih, 2014; Lancioni, Singh, O'Reilly, Sigafoos, Oliva, Campodonico, Alberti \& Lang, 2014; Lancioni, Singh, O’Reilly, Sigafoos, Boccasini, Alberti \& Lang, 2014; Lancioni, O’Reilly, Singh, Sigafoos, Alberti, Boccasini, Oliva \& Lang, 2014; Lancioni, O’Reilly, Singh, Sigafoos, Oliva, Alberti, Carrella, Didden \& Lang, 2013; Ramani, Police \& Jacob, 2014; Lancioni, O’Reilly, Singh, Sigafoos, Oliva, Campodonico \& Lang, 2012; Johnson \& Parker, 2013; Lancioni, Singh, O’Reilly, Green, Oliva, Buonocunto, Sacco, Biancardi \& Di Nuovo, 2012; Lancioni, O'Reilly, Singh, Green, Oliva, Buonocunto, Colonna \& Navarro, 2012; Shih, 2011; Taylor \& Preece, 2010; Lancioni, Bellini, Oliva, Singh, O’Reilly, Lang, Didden \& Bosco, 2011; Ricci, Miglino, Alberti, Perilli \& Lancioni, 2017; Sadler, 2019; Stasolla, Caffo, Perilli, Boccasini, Stella, Damiani, Albano \& Damato, 2017

Studies that suggest to Bosch, Andringa, Peterson, Ruijssenaars \& Vlaskamp, 


adapting and Lancioni, Singh, O'Reilly, Sigafoos, Alberti \&

developing the tool Campodonico, 2016; Lancioni, O’Reilly, Singh, Sigafoos, Boccasini, Martire, Perilli \& Spagnuolo, 2016; Lancioni, Singh, O'Reilly, Sigafoos, D’Amico, Buonocunto, Navarro, Lanzilotti \& Alberti, 2017; Lancioni, Singh, O'Reilly, Sigafoos, Boccasini, Martire, Oliva \& Lang, 2014; Lancioni, Singh, O’Reilly, Sigafoos, Boccasini, Alberti \& Lang, 2014; Shih, 2014; Lancioni, Singh, O’Reilly, Sigafoos, Oliva, Alberti \& Buono, 2014; Lancioni, O’Reilly, Singh, Sigafoos, Oliva, Alberti, Carrella, Didden \& Lang, 2013; Shih, 2013; Shih, 2012; Lancioni, Singh, O'Reilly, Green, Oliva, Buonocunto, Sacco, Biancardi \& Di Nuovo, 2012; Mechling and Bishop, 2011; Shih, Shih and Wang, 2010; Poppes, Putten, Frans, Brug and Vlaskamp, 2016; Shih, Cheng, Li, Shih and Chiang, 2010.

Studies that suggest to Lancioni, O’Reilly, Singh, Green, Oliva, Campodonico, collect social validity Lang and Buono, 2013; Lancioni, Singh, O’Reilly, data Sigafoos, Belardinelli, Buonocunto, D'Amico, Navarro, Lanzilotti, Denitto, Tommaso and Megna, 2015; Lancioni, Singh, O’Reilly, Green, Meer, Alberti, Perilli, Boccasini, Martire and Lang, 2015; Lancioni, Singh, O'Reilly, Sigafoos, Boccasini, Alberti and Lang, 2014; Lancioni, Singh, O’Reilly, Sigafoos, Oliva, Campodonico, Alberti and Lang, 2014; Lancioni, O'Reilly, Singh, Sigafoos, Alberti, Boccasini, Oliva and Lang, 2014; Lancioni, Singh, O’Reilly, Sigafoos, Boccasini, Martire and Lang, 2014; Lancioni, O'Reilly, Singh, Sigafoos, Oliva, Alberti, Carrella, Didden and Lang, 2013; Lancioni, O’Reilly, Singh, Green, Oliva, Buonocunto, Colonna and Navarro, 2012; Lancioni, O’Reilly, Singh, Sigafoos, Oliva, Campodonico and Lang, 2012; Lancioni, Singh, O'Reilly, Green, Oliva, Buonocunto, Sacco, Biancardi and Di Nuovo, 2012; Mechling and Bishop, 2011.

\begin{tabular}{|c|c|c|c|}
\hline $\begin{array}{l}\text { Studies that suggest to } \\
\text { be repeated by } \\
\text { increasing } \\
\text { researcher's } \\
\text { component }\end{array}$ & $\begin{array}{l}\text { Munde and Vlaskamp, 2014; Argyropoulos and } \\
\text { Thymakis, 2014; Nelson, Greenfield, Hyte and Shaffer, } \\
\text { 2013; Trief, Cascella and Bruce, 2013; Hostyn and } \\
\text { Maes, 2013. }\end{array}$ & 5 & 4.23 \\
\hline $\begin{array}{l}\text { Studies that suggest to } \\
\text { be repeated for } \\
\text { different skills }\end{array}$ & $\begin{array}{l}\text { Lancioni, Singh, O’Reilly, Sigafoos, Boccasini, Martire } \\
\text { and Lang, 2014; Lancioni, O’Reilly, Singh, Green, Oliva, } \\
\text { Buonocunto, Colonna and Navarro, 2012; Munde, } \\
\text { Vlakamp, Maes and Ruijssenaars, 2012. }\end{array}$ & 3 & 2.54 \\
\hline $\begin{array}{l}\text { Studies that suggest to } \\
\text { be repeated by } \\
\text { lowering the cost }\end{array}$ & $\begin{array}{l}\text { Lancioni, Singh, O'Reilly, Green, Meer, Alberti, Perilli, } \\
\text { Boccasini, Martire and Lang, 2015; Lancioni, Singh, } \\
\text { O’Reilly, Green, Oliva and Campodonico, } 2013 .\end{array}$ & 2 & 1.69 \\
\hline $\begin{array}{l}\text { Studies that suggest to } \\
\text { take participant's } \\
\text { opinion }\end{array}$ & $\begin{array}{l}\text { Poppes, Putten and Vlaskamp, 2014; Lancioni, O’Reilly, } \\
\text { Singh, Sigafoos, Oliva, Campodonico and Lang, } 2012 .\end{array}$ & 2 & 1.69 \\
\hline $\begin{array}{l}\text { Study that suggest to } \\
\text { generalize the taught } \\
\text { skill to home }\end{array}$ & $\begin{array}{l}\text { Axelsson, Granlund and Wilder, 2013; Lancioni, Singh, } \\
\text { O'Reilly, Sigafoos, Oliva, Signorino and Tommaso, } 2010 .\end{array}$ & 2 & 1.69 \\
\hline $\begin{array}{l}\text { Studies that suggest to } \\
\text { developing standards }\end{array}$ & Wei, Blackorby and Schiller, 2011. & 1 & 0.84 \\
\hline
\end{tabular}




\begin{tabular}{|c|c|c|c|}
\hline $\begin{array}{l}\text { Study that suggest to } \\
\text { teach same skill with } \\
\text { different technologic } \\
\text { tool }\end{array}$ & Blain-Moraes and Chau, 2012 & 1 & 0.84 \\
\hline $\begin{array}{l}\text { Study that suggest to } \\
\text { use acquired skill as a } \\
\text { prerequisite skill }\end{array}$ & Moir, 2010 & 1 & 0.84 \\
\hline $\begin{array}{l}\text { Study that suggest the } \\
\text { early intervention }\end{array}$ & Kumar, 2013 & 1 & 0.84 \\
\hline
\end{tabular}

In $26,27 \%$ of the studies, researchers suggested repeating the study with individuals with different inabilities. When it is thought that more than half of the studies examined $(66,66$ $\%)$ were made through single-subject research model, that suggestion is natural to be done for the generalizability of the findings of the researches in that model. Generalizability in single-subject research models, semi-experimental studies, is obtained through repeated studies.

In $33.05 \%$ of the studies, it is recommended to "systematize the application, develop and repeat it", and in $4.23 \%$ "repeat the application by increasing the competence of the practitioner". Considering the findings about the limitations, it is seen that there is a limitation regarding the application. For this reason, some of the studies suggest that "the same study should be studied experimentally".

In $10,16 \%$ of the studies, it was stated that social validity data could not be collected for different reasons, and they were expressed as suggestions for the future studies. It was reported as a result of the studies that acquisitions of the individuals with multiple and severe inabilities affected positively the parents, the caretakers, and the other specialists and persons interacting with them, but that lack of data about it was a loss. In some of the studies are works suggesting "asking the opinion of the participant/subject".

In $12 \%$ of the studies in which technologically supported applications were made, it was noticed that the application could be performed more easily if some more adaptation was ensured during the application, the application was continued due to the research systematics, but this information was conveyed to the future researchers as a suggestion.

\section{RESULTS, DISCUSSIONS AND SUGGESTIONS}

Findings of the research reveal that individuals with multiple disabilities and inabilities could be taught many skills such as interaction skills, communication skills, motor skills, daily life skills, leisure time and play skills, academic and occupational skills. Findings show that individuals, whether adults or children, with multiple disabilities and inabilities could acquire every behavior and skill aimed to teach them.

According to the findings of the research, most of the 96 studies (33) used single-subject research models. All the studies using it were effective in teaching the target behaviors. The studies made with the aim of skills teaching in our country also used single-subject 
research model (Düzkantar, 2014; Eldeniz-Çetin, 2013; Bahçeci \& Sarı, 2009). It was found that all the target behaviors were also taught in those studies. Therefore, singlesubject research models could be easily preferred in the future studies about the individuals with multiple disabilities and inabilities. These findings suggest that scientificbased applications similar to the studies conducted in the field of single disability can also be done for individuals with multiple disabilities.

In the research, when the findings of the 96 articles were examined, they revealed that technology-aided implementations to teach the individuals with multiple disabilities and inabilities skills and to change their behaviors were effective (Argyropoulos \& Thymakis, 2014; Ching-Hsiang Shih, 2014; Ching-Hsiang Shih, 2013; Lancioni et al., 2012; Lancioni et al., 2006; Lancioni et al., 2010; Moir, 2010; Shih, 2011; Shih et al., 2010; Shih et al., 2010). It was thought that the technological devices used in the studies were also being used in our country, accordingly similar studies whose efficiency was proved could be made in our country. The findings show that individuals with multiple disabilities and inabilities could be taught interaction and communication skills via technology-aided practices, and they could be helped to interact with the environment. Studies aiming the fundamental interaction skills increased the quality of life of the individuals with multiple disabilities and inabilities, and they were helped to express their preferences (Johnson and Parker, 2013; Kumar, 2013; Lancioni et al., 2015; Lancioni et al., 2014; Lancioni et al., 2014; Lancioni et al., 2011).

Being able to interact with its environment as a social being is indispensable for individuals with multiple disabilities as well as for all individuals. Findings of the research revealed that problematic behaviors of the individuals with multiple disabilities and inabilities could be decreased through certain practices (Poppes et al., 2014; Desrochers et al., 2014; Lancioni and 2013). This finding indicates that the problem behaviors that harm the individual should not be attributed to his or her multiple inabilities and those attempts should be initiated to eliminate them through systematic studies.

Even if they are limited in number, findings of the research show that individuals with multiple disabilities and inabilities could be taught academic skills (Jongbloed et al., 2015; Ramani, Police and Jacob, 2012; Wei, Blackorby and Schiller, 2011). The mentioned studies reveal that they could be taught how to read and write, and the efforts should never stop. In all of the studies, reading and writing skills were studied in a technologyaided way, hand-writing and pronunciation were not considered as prerequisites. Touching only on a touch-screen was thought to be a satisfactory motor skill to learn how to write.

Studies made in literature and in our country make one think that studies for the individuals with multiple disabilities and inabilities should continue increasingly. It is known that individuals with severe and multiple inability is $1 \%$ of the general population. Moreover, $40 \%$ of that percentage have additional inabilities (Tam, Phillips \& Mudford, 2011; Hardin, 2006). Multiple disabled individuals have serious difficulties in living independently and require support forever because of the difficulties in motor skills, 
cognitive skills, social skills and self care skills (Orelove \& Sobsey, 1996). Therefore, when the people in the immediate environment responsible for the care of the individuals with multiple and severe inabilities are thought, it is a problem affecting the $5 \%$ of the general population.

In this study, the findings of the researchers who want to do research on individuals with multiple and severe disabilities tend to be technologically-supported ones. The technology used does not require complex technical infrastructure. However, it is worth noting that when field experts have hesitations, they can start their studies by cooperating with non-field experts who have technical knowledge.

It is recommended that practitioners who work with individuals with multiple and severe disabilities should not hesitate to start their studies with evidence-based studies, examples and results of which are shared in this study, without worrying about failing in the studies they plan to do.

\section{References}

The U.S. Department of Education. Building the legacy: IDEA 2004. Retrieved from http://idea.ed.gov/explore/home

Akçamete, G. (1992). Çoklu engelli çocuklar [Children with multiple disabilities]. Ankara Üniversitesi Eğitim Fakültesi Dergisi, 24(1), 145-150.

Argyropoulos. V., \& Thymakis, P. (2014). Multiple disabilities and visual impairment: an action research project. Journal of Visual Impairment ve Blindness, 108(2), 163.

Axelsson, A. K., Granlund, M., \& Wilder, J. (2014) Engagement in family activities: a quantitative, comparative study of children with profound intellectual and multiple disabilities and children with typical development. Child Care Health and Development, 40(4), 457-457.

Bahçeci, B. (2009). Çok engelli çocuklara iletişim becerilerinin kazandırılmasında yoğunlaştırılmış karşıllıklı etkileşim yönteminin etkililiğinin değerlendirilmesi [Evaluation of the Efficacy of the Intensive Interaction Method in Developing Communication Skills in Children with Multiple Disabilities] (Yüksek Lisans Tezi). Selçuk Üniversitesi Sosyal Bilimler Enstitüsü, Konya.

Bahçıvancıoğlu-Yazıcı, A., \& Akçin, N. (2014). Çoklu yetersizliği olan çocukların annelerinin çocuklarının gelişimlerine ilişkin görüşlerinin betimlenmesi [Describing mother's opinions about development

Process of their children with multiple disability]. Ahi Evran Üniversitesi Kırșehir Eğitim Fakültesi Dergisi, 15(2).

Benford, F. (2017). Use of powered mobility for a young adult with profound and multiple learning disabilities: a practice analysis. British journal of occupational therapy, 80(8), 517-520.

Blain-Moraes, S., \& Chau, T. (2012). Challenges of developing communicative interaction in individuals with congenital profound intellectual and multiple disabilities. Journal of Intellectual ve Developmental Disability, 37(4), 348-359.

Boas, D. C., Ferreira, L. P., de Moura, M. C., Maia, S. R. \& Amaral, I. (2016). Analysis of interaction andnattention processes in a child with congenital deafblindness. American Annals of the Deaf, 161(3), 327-341.

Bosch, K. A., Andringa, T. C., Peterson, W., Ruijssenaars, W. A. \& Vlaskamp, C. (2017). A comparison of natural and non-natural soundscapes on people with severe or profound intellectual and multiple disabilities. Journal of Intellectual \& Developmental Disability, 42(3), 301-307. 
Bossink, L. W., van der Putten, A. A., Waninge, A. \& Vlaskamp, C. (2017). A power-assisted exercise intervention in people with profound intellectual and multiple disabilities living in a residential facility: a pilot randomised controlled trial. Clinical Rehabilitation, 31(9), 1168-1178.

Brug, A., Van der Putten, A. A. J., Penne, A., Maes, B. \& Vlaskamp, C. (2016). Making a difference? A comparison between multi-sensory and regular storytelling for persons with profound intellectual and multiple disabilities. Journal of Intellectual Disability Research, 60(11), 1043-1053.

Bullen, A., Luger, R., Prudhomme, D. \& Geiger, M. (2018). Simple ideas that work: Celebrating development in persons with profound intellectual and multiple disabilities. African Journal of Disability (Online), 7, 110.

Chang, Y. J., Lee, M. Y., Chou, L. D., Chen, S. F. \& Chen, Y. C. (2011). A mobile wetness detection system enabling teachers to toilet train children with intellectual disabilities in a public school setting. Journal of Developmental and Physical Disabilities, 23(6), 527-533.

Cunha, R. D., Neiva, F. W., \& Silva, R. L. D. S. (2019). Virtual reality-based training for the motor development of people with intellectual and multiple disabilities. Revista de Informática Teórica e Aplicada, 26(3), 40-49.

Çalık, M., \& Sözbilir, M. (2014). İçerik analizinin parametreleri [Parameters of content analysis]. Eğitim ve Bilim, 39, 33-38.

Dayı, E., \& Şafak, P. (2018). Toilet training to a child with multiple disabilities using a toilet training package including" token economy" system: a case study. Egitim ve Bilim, 43(196), 301-316.

Delden, R. W., Wintels, S. C., van Oorsouw, W. M. W. J., Evers, V., Embregts, P. J. C. M., Heylen, D. K. J., \& Reidsma, D. (2020). Alertness, movement, and affective behavior of people with profound intellectual and multiple disabilities (PIMD) on introduction of a playful interactive product: Can we get your attention?. Journal of Intellectual \& Developmental Disability, 45(1), 66-77.

Depountis, V., Okungu, P., \& Molloy-Daugherty, D. (2019). The development of an application that supports body awareness for children with visual impairments and additional disabilities. Vision Rehabilitation International, 10(1), 1-8.

Desideri, L., Bizzarri, M., Bitelli, C., Roentgen, U., Gelderblom, G. J., \& Witte, L. (2016). Implementing a routine outcome assessment procedure to evaluate the quality of assistive technology service delivery for children with physical or multiple disabilities: Perceived effectiveness, social cost, and user satisfaction. Assistive Technology, 28(1), 30-40.

Desrochers, M. N., Oshlag, R., \& Kennelly, A. M. (2014). Using background music to reduce problem behavior during assessment with an adolescent who is blind with multiple disabilities. Journal of Visual Impairment ve Blindness, 108(1), 31-66.

World Health Organization, (1997). Let's Communicate", Section 7, Retrieved from http://whqlibdoc.who.int/hq/1997/WHO RHB 97.1 7.pdf

Düzkantar, A. (2014). Efficacy of teaching with simultaneous prompting in teaching the environmental sounds to a child with multiple disabilities. Hacettepe Üniversitesi Eğitim Fakültesi Dergisi, 29(1), 87-98.

Eldeniz Cetin, M., \& Bozak, B. (2020). The effectiveness of a training package prepared to teach first aid skills to individuals with intellectual and additional disabilities. International Education Studies, 13(3), 2742.

Felício, F. A. D. S., Seabra Junior, M. O., \& Rodrigues, V. (2019). Educational Toys Associated with Storytelling Used with a Child with Multiple Disabilities. Revista Brasileira de Educação Especial, 25(1), 67-84.

Ferreira, M. I. J., Travassos, X. L., Alves, L., Sampaio, R., \& Pereira-Guizzo, C. S. (2013). Digital games and assistive technology: Improvement of communication of children with cerebral palsy. International Journal of Special Education, 28(1), 36-46.

Ferreira, M. D. P., Zotz, T. G., Melo, T. R., \& Israel, V. L. (2019). Reports of case series of institutionalized adults with multiple disabilities: how to assess functionality?. Revista Brasileira de Educação Especial, 25(1), 55-66. 
Frederiks, K., Sterkenburg, P., Barakova, E., \& Feijs, L. (2019). The effects of a bioresponse system on the joint attention behaviour of adults with visual and severe or profound intellectual disabilities and their affective mutuality with their caregivers. Journal of Applied Research in Intellectual Disabilities, 32(4), 890-900.

Gargiulo, R. M. (2004). Special education in contemporary society an introduction to exceptionality. Belmont: Thomson Wadsworth.

Hanzen, G., van Nispen, R. M., Vlaskamp, C., Korevaar, E. L., Waninge, A., \& Van der Putten, A. A. (2020). Improving the participation of adults with visual and severe or profound intellectual disabilities: a process evaluation of a new intervention. BMC Health Services Research, 20, 1-15.

Holmqvist, E., Derbring, S., \& Wallin, S. (2017). Participation through gaze controlled computer for children with severe multiple disabilities. Studies in Health Technology and Informatics, 242, 1103-1108.

Holyfield, C., Light, J., Drager, K., McNaughton, D., \& Gormley, J. (2018). Effect of AAC partner training using video on peers' interpretation of the behaviors of presymbolic middle-schoolers with multiple disabilities. Augmentative and Alternative Communication, 34(4), 301-310.

Holyfield, C. (2019). Preliminary investigation of the effects of a prelinguistic AAC intervention on social gaze behaviors from school-age children with multiple disabilities. Augmentative and Alternative Communication, 35(4), 285-298.

Holyfield, C., Brooks, S., \& Schluterman, A. (2019). Comparative effects of high-tech visual scene displays and low-tech isolated picture symbols on engagement from students with multiple disabilities. Language, Speech, And Hearing Services in Schools, 50(4), 693-702.

Holyfield, C., Caron, J., Light, J., \& McNaughton, D. (2019). Effect of video embedded with hotspots with dynamic text on single-word recognition by children with multiple disabilities. Journal of Developmental and Physical Disabilities, 31(6), 727-740.

Hostyn, I. ve Maes, B. (2013). Interaction with a person with profound intellectual and multiple disabilities: A case study in dialogue with an experienced staff member. Journal of Intellectual and Developmental Disability, 38(3), 189-204.

Hudson, M. E., Zambone, A., \& Brickhouse, J. (2016). Teaching early numeracy skills using single switch voiceoutput devices to students with severe multiple disabilities. Journal of Developmental and Physical Disabilities, 28(1), 153-175.

Ivy, S. E., Hatton, D. D., \& Wehby, J. H. (2018). Using graduated guidance to teach spoon use to children with severe multiple disabilities including visual impairment. Research and Practice for Persons with Severe Disabilities, 43(4), 252-268.

Janssen, M. J., N Brink-Groenendijk, C. R., Riksen-Walraven, M., Huisman, M., Van Dijk, J. P., \& Ruijssenaars. W. A. (2014). Measuring sustained interaction in adults with deafblindnessand multiple disabilities: Development of an observational coding system. British Journal of Visual Impairment, 32(2) 68-76.

Johnson, N., \& Parker, A. T. (2013). Effects of wait time when communicating with children who have sensory and additional disabilities. Journal of Visual Impairment ve Blindness, 107(5), 363.

Jongbloed-Pereboom, M., Peeters, A., Overvelde, A., Nijhuis-van der Sanden, M. W. G., \& Steenbergen, B. (2015). Learning of writing letter-like sequences in children with physical and multiple disabilities. Research in Developmental Disabilities, 36, 150-161

Kemp, C., Stephenson, J., Cooper, M., \& Hodge, K. (2016). Engaging preschool children with severe and multiple disabilities using books and iPad apps. Infants \& Young Children, 29(4), 249-266.

Knapik-Szweda, S. M. (2019, February). The significance of the process of music therapy for children with multiple social and communication disabilities. In Voices: A World Forum for Music Therapyi 19(1),

Krämer, T., \& Zentel, P. (2020). Expression of emotions of people with profound intellectual and multiple disabilities. A single-case design including physiological data. Psychoeducational Assessment, Intervention and Rehabilitation, 2(1), 15-29.

Kumar, N. (2013). Early intervention of a child with multiple disabilities-a case study. Language in India, 13(2). 
Lancioni, G. E., Singh, N., O'Reilly, M. F, Sigafoos, J., Boccasini, A., La Martire L., Oliva D., \& Lang, R. (2014). Orientation technology to help persons with blindness and multiple disabilities manage indoor travel and travel-related anxiety. Journal of Intellectual and Developmental Disability, 39(2), 198-205.

Lancioni G. E., Singh, N., O’Reilly, M.F., Sigafoos J., Oliva, D., Alberti, G., \& Buono, S. (2014). Persons with multiple disabilities choose among environmental stimuli using a smile response and a technology-aided program. Journal of Intellectual and Developmental Disability, 26, 183-191.

Lancioni G.E., Singh, N., O'Reilly, M. F., Sigafoos, J., Oliva, D., Campodonicoe, F., Alberti, G., \& Lang, R. (2014). Persons with multiple disabilities exercise a complex response scheme to counter incorrect head and shoulder positions via a microswitch-aided program. Journal of Intellectual and Developmental Disability, 39(4), 363-369.

Lancioni, G, E., O’Reilly, M., Singh, N., Sigafoos, J., Oliva, D., Campodonico, F., \& Lang, R. (2012). Persons with multiple disabilities exercise adaptive head and hand-eye responses using technology-aided programs: two single-case studies. Journal of Developmental ve Physical Disabilities, 24(4), 415-426.

Lancioni, G. E., Bellini, D., Oliva, D., Singh, N. N., O’reilly, M. F., Lang, R., Didden, R., \& Bosco, A. (2011). Persons with multiple disabilities select environmental stimuli through a smile response monitored via camera-based technology. Developmental Neurorehabilitation, 14(5), 267-273.

Lancioni, G. E., O’reilly, M. F., Singh, N. N., Green, V. A., Oliva, D., Campodonico, F., Lang, R., \& Buono, S. (2013). Technology-aided programs to support exercise of adaptive head responses or leg-foot and hands responses in children with multiple disabilities. Developmental Neurorehabilitation, 16(4), 237-244.

Lancioni, G. E., O’reilly, M. F., Singh, N. N., Green, V. A., Oliva, D., Buonocunto, F., Colonna, F., \& Navarro, J. (2012). Special text messaging communication systems for persons with multiple disabilities. Developmental Neurorehabilitation, 15(1), 31-38.

Lancioni, G. E., O'reilly, M., Singh, N., Sigafoos, J., Oliva, D., Alberti, G., Carella, L., Didden, R., \& Lang, R. (2013). Technology-based programs to support adaptive responding and reduce hand mouthing in two persons with multiple disabilities. Journal of Developmental and Physical Disabilities, 25(1), 65-77.

Lancioni, G. E., O'reilly, M. F., Singh, N. N., Sigafoos, J., Alberti, G., Boccasini, A., Oliva, D., \& Lang, R. (2014). Technology-aided programs to enable persons with multiple disabilities to move through sequences of occupational activities independently. Journal of Developmental and Physical Disabilities, 26(6), 703715.

Lancioni, G. E., Singh, N. N., O’reilly, M. F., Sigafoos, J., Boccasini, A., La-Martire, M. L., \& Lang, R. (2014). Case studies of technology for adults with multiple disabilities to make telephone calls independently. Perceptual and Motor Skills, 119(1), 320-331.

Lancioni, G. E., Singh, N. N., O'reilly, M. F., Green, V. A., Oliva, D., Buonocunto, F., Sacco, V., Biancardi, E. M., \& Nuovo, S. D. (2012). Technology-based programs to support forms of leisure engagement and communication for persons with multiple disabilities: Two single-case studies. Developmental Neurorehabilitation, 15(3), 209-218.

Lancioni, G. E., Singh, N. N., O’Reilly, M. F., Green, V. A., Van der Meer, L., Alberti, G., Perilli, V., Boccasini, A., Martire, M., \& Lang, R. (2015). A speech generating device for persons with intellectual and sensorymotor disabilities. Journal of Developmental and Physical Disabilities, 27(1), 1-14.

Lancioni, G. E., Singh, N. N., O’reilly, M. F., Sigafoos, J., Belardinelli, M. O., Buonocunto, F., D’Amico, F., Navarro, J., Lanzilotti, C., Denitto, F., Tommaso, M. D., \& Megna, M. (2015). Supporting self-managed leisure engagement and communication in post-coma persons with multiple disabilities. Research in Developmental Disabilities, 38, 75-83.

Lancioni, G. E., Singh, N. N., O'Reilly, M. F., Green, V. A., Oliva, D., \& Campodonico, F. (2013). Two men with multiple disabilities carry out an assembly work activity with the support of a technology system. Developmental Neurorehabilitation, 16(5), 332-339. 
Lancioni, G. E., Singh, N. N., O'Reilly, M. F., Sigafoos, J., Oliva, D., Signorino, M., \& De Tommaso, M. (2010). Helping a man with acquired brain injury and multiple disabilities manage television use via assistive technology. Clinical Case Studies, 9(4), 285-293.

Lancioni, G. E., Singh, N., O’Reilly, M. F., Sigafoos, J., Boccasini, A., Alberti, G., \& Lang, R. (2014). People with multiple disabilities use basic reminding technology to engage in daily activities at the appropriate times. Journal of Intellectual and Developmental Disability, 26(3), 347-355.

Lancioni, G. E., Singh, N. N., O’Reilly, M. F., Sigafoos, J., Alberti, G., \& Campodonico, F. (2016). Case studies of technology-aided interventions to promote hand reaching and standing or basic ambulation in persons with multiple disabilities. Perceptual and Motor Skills, 122(1), 200-219.

Lancioni, G. E., O’Reilly, M. F., Singh, N. N., Sigafoos, J., Boccasini, A., La Martire, M. L., \& Spagnuolo, C. (2016). Technology to support positive occupational engagement and communication in persons with multiple disabilities. International Journal on Disability and Human Development, 15(1), 111-116.

Lancioni, G. E., Singh, N. N., O’Reilly, M. F., Sigafoos, J., Boccasini, A., La Martire, M. L., \& Smaldone, A. (2016). People with multiple disabilities use assistive technology to perform complex activities at the appropriate time. International. Journal on Disability and Human Development, 15(3), 261-266.

Lancioni, G. E., Singh, N. N., O’Reilly, M. F., Sigafoos, J., Alberti, G., Perilli, V., \& Zagaria, T. (2017). Technologyaided options for helping persons with multiple disabilities engage in communication behavior. Life Span and Disability, 20(1), 7-26.

Lancioni, G. E., Singh, N. N., O'Reilly, M. F., Sigafoos, J., Campodonico, F., \& Alberti, G. (2017). Use of a smartphone for leisure and communication by people with blindness and motor disabilities. Journal of Visual Impairment \& Blindness, 111(2), 181-186.

Lancioni, G. E., O’Reilly, M. F., Sigafoos, J., Campodonico, F., Perilli, V., Alberti, G., \& Miglino, O. (2018). A modified smartphone-based program to support leisure and communication activities in people with multiple disabilities. Advances in Neurodevelopmental Disorders, 2(3), 293-299.

Lancioni, G. E., Singh, N. N., O’Reilly, M. F., Sigafoos, J., D’Amico, F., Buonocunto, F., \& Alberti, G. (2017). Diversified occupation and communication program versions for persons with acquired neurological damage and multiple disabilities. International Journal on Disability and Human Development, 16(3), 259-265.

Lancioni, G. E., Singh, N. N., O’Reilly, M. F., Sigafoos, J., Alberti, G., Perilli, V., \& Campodonico, F. (2017). Promoting functional activity engagement in people with multiple disabilities through the use of microswitch-aided programs. Frontiers in Public Health, 5(205), 1-8.

Lancioni, G. E., Singh, N. N., O’Reilly, M. F., Sigafoos, J., Alberti, G., Zimbaro, C., \& Chiariello, V. (2017). Using smartphones to help people with intellectual and sensory disabilities perform daily activities. Frontiers In Public Health, 5 (282), 1-8.

Lancioni, G. E., Singh, N. N., O’Reilly, M. F., Sigafoos, J., Alberti, G., Campodonico, F., \& Zimbaro, C. (2017). A technology-aided program to support basic occupational engagement and mobility in persons with multiple disabilities. Frontiers in Public Health, 5(338), 1-8.

Lancioni, G. E., Singh, N. N., O’Reilly, M. F., Sigafoos, J., Boccasini, A., Perilli, V., \& Spagnuolo, C. (2017). Persons with multiple disabilities manage positive leisure and communication engagement through a technology-aided program. International Journal of Developmental Disabilities, 63(3), 148-157.

Lancioni, G. E., Singh, N. N., O’Reilly, M. F., Sigafoos, J., Alberti, G., Perilli, V., \& Russo, R. (2018). Promoting physical activity in people with intellectual and multiple disabilities through a basic technology-aided program. Journal of Intellectual Disabilities, 22(2), 113-124.

Lancioni, G. E., Singh, N. N., O’Reilly, M. F., Sigafoos, J., Campodonico, F., Zimbaro, C., \& Zagaria, T. (2018). Helping people with multiple disabilities manage an assembly task and mobility via technologyregulated sequence cues and contingent stimulation. Life Span and Disability, 21, 143-63. 
Lancioni, G. E., Singh, N. N., O’Reilly, M. F., Sigafoos, J., Campodonico, F., Oliva, D., \& D’amico, F. (2018). Using microswitch-aided programs for people with multiple disabilities to promote stimulation control and mild physical exercise. Journal of Intellectual \& Developmental Disability, 43(2), 242-250.

Lancioni, G. E., Singh, N. N., O’Reilly, M. F., Sigafoos, J., Alberti, G., Perilli, V., \& Campodonico, F. (2018). Supporting leisure and functional activity engagement in people with multiple disabilities via a technology-aided program. Technology and Disability, 29(4), 173-181.

Lancioni, G. E., Singh, N. N., O’Reilly, M. F., Sigafoos, J., Resta, E., Campodonico, F., \& Chiariello, V. (2020). Selfregulated versus staff-regulated stimulation for promoting indices of satisfaction in persons with severe/profound and multiple disabilities. Journal of Developmental and Physical Disabilities, 1-16.

Lancioni, G. E., Singh, N. N., O’Reilly, M. F., Sigafoos, J., Alberti, G., Chiariello, V., \& Carrella, L. (2020). Everyday Technology to Support Leisure and Daily Activities in People with Intellectual and Other Disabilities. Developmental Neurorehabilitation,

Mechling, L. C., \& Bishop, V. A. (2011). Assessment of computer-based preferences of students with profound multiple disabilities. The Journal of Special Education, 45(1), 15-27.

Moir, L. (2010). Evaluating the effectiveness of different environments on the learning of switching skills in children with severe and profound multiple disabilities. The British Journal of Occupational Therapy, 73(10), 446-456.

Munde, V., \& Vlaskamp, C. (2014). Initiation of activities and alertness in individuals with profound intellectual and multiple disabilities. Journal of Intellectual Disability Research, 50(3), 284-292.

Munde, V.S., Vlaskamp, C., Maes, B., \& Ruijssenaars, A. J. J., M. (2012). Catch the wave! Time-window sequential analysis of alertness stimulation in individuals with profound intellectual and multiple disabilities. Child: Care, Health and Development, 40(1), 95-105.

Nakken, H., \& Vlaskamp, C. (2007). A need for a taxonomy for profound intellectual and multiple disabilities. Journal of Policy and Practice in Intellectual Disabilities, 4(2), 83-87.

Neagu, N. \& Zsuzsanna, K. (2017). Hippotherapy as complementary method in the rehabilitation of children with multiple disabilities. Romanian Journal of Experimental Applied Psychology, 8(2), 24-36.

Nelson, C., Greenfield, R. G., Hyte, H. A., \& Shaffer, J. P. (2013). Stress, behavior, and children and youth who are deafblind. Research ve Practice for Persons with Severe Disabilities, 38(3), 139-156.

Nijs, S., Vlaskamp, C. \& Maes, B. (2018). Promoting social scaffolding behaviors in staff members and peerdirected behaviors among persons with profound intellectual and multiple disabilities: an intervention study. Journal of Policy and Practice in Intellectual Disabilities, 15(2), 124-135.

Orelove, F. P., \& Sobsey, D. R. N. (1996). Educating Children with Multpile Disabilities A Transdisciplinary Approach. Baltimore; Paul H. Brookes Publishig Co.

Pereboom M. J., Peeters A., Overvelde, A., Nijhuis-van der Sanden, M. W.G., \& Steenbergen, B. (2015). Learning of writing letter-like sequences in children with physical and multiple disabilities. Research in Developmental Disabilities, 36, 150-16.

Pilesjö, M., \& Norén, N. (2017). Teaching communication aid use in everyday conversation. Child Language Teaching and Therapy, 33(3), 241-253.

Poppes, P., Van der Putten, A. A., \& Vlaskamp, C. (2014). Addressing challenging behavior in people with profound intellectual and multiple disabilities: analyzing the effects of daily practice. Journal of Policy and Practice in Intellectual Disabilities, 11(2), 128-136.

Poppes, P., van der Putten, A., Post, W., Frans, N., Ten Brug, A., van Es, A., \& Vlaskamp, C. (2016). Relabelling behaviour. The effects of psycho-education on the perceived severity and causes of challenging behaviour in people with profound intellectual and multiple disabilities. Journal of Intellectual Disability Research, 60(12), 1140-1152.

Ramani, K. K., Police, S. R., \& Jacob, N. (2014). Impact of low vision care on reading performance in children with multiple disabilities and visual impairment. Indian Journal of Ophthalmology, 62(2), 111. 
Ricci, C., Miglino, O., Alberti, G., Perilli, V., \& Lancioni, G. E. (2017). Speech generating technology to support request responses of persons with intellectual and multiple disabilities. International Journal of Developmental Disabilities, 63(4), 238-245.

Sadler, K. M. (2019). Video self-modeling and functional behavior assessment to modify aggressive behaviors in students with autism spectrum disorder and intellectual disabilities. Education and Training in Autism and Developmental Disabilities, 54(4), 406-419.

Shih, C. H. (2011). Assisting people with multiple disabilities and minimal motor behavior to improve computer Drag-and-Drop efficiency through a mouse wheel. Research in Developmental Disabilities, 32(6), 2867-2874.

Shih, C. H. (2012). Using an Extended Dynamic Drag-and-Drop Assistive Program to assist people with multiple disabilities and minimal motor control to improve computer Drag-and-Drop ability through a mouse wheel. Research in Developmental Disabilities, 33(2), 621-629.

Shih, C. H., Cheng, H. F., Li, C. C., Shih, C. T., \& Chiang, M. S. (2010). Assisting people with developmental disabilities improve their collaborative pointing efficiency with a Multiple Cursor Automatic Pointing Assistive Program. Research in Developmental Disabilities, 31(2), 600-607.

Shih, C. H., Shih, C. T., \& Wang, S. K. (2010). Assisting people with disabilities improves their collaborative pointing efficiency with a Multiple Cursor Dynamic Pointing Assistive Program. Research in Developmental Disabilities, 31(6), 1251-1257.

Shih, C. H. (2013). Assisting people with disabilities improves their collaborative pointing efficiency through the use of the mouse scroll Wheel. Research in Developmental Disabilities, 34(1), 1-10

Shih, C. H. (2014). Assisting people with multiple disabilities to improve computer typing efficiency through a mouse wheel and on-screen keyboard software. Research in Developmental Disabilities, 35(9), 21292136.

Shogren, K. A., Kennedy, W., Dowsett, C., \& Little, T.D. (2014). Autonomy, psychological empowerment y and self-realization: exploring data on self-determination from NLTS2. Exceptional Children, 80(2), 221235.

Stasolla, F., Caffò, A. O., Perilli, V., Boccasini, A., Stella, A., Damiani, R., \& Damato, C. (2017). A microswitchbased program for promoting initial ambulation responses: An evaluation with two girls with multiple disabilities. Journal of Applied Behavior Analysis, 50(2), 345-356.

Taylor, K., \& Preece, D. (2010). Using aspects of the TEACCH structured teaching approach with students with multiple disabilities and visual impairment: Reflections on practice. British Journal of Visual Impairment, 28(3), 244-259.

Tekin-İftar, E. (2000). İleri derecede ve çoklu yetersizlikler [Profound and multiple disabilities], Eripek, S. (Ed.) Özel eğitim. (s. 81-96). Eskişehir, Anadolu Üniversitesi Yayınları.

Trief, E., Cascella, P. W., \& Bruce, S. M. (2013). A field study of a standardized tangible symbol system for learners who are visually impaired and have multiple disabilities. Journal of Visual Impairment and Blindness, 107(3), 180-191.

Turnbull, R., Turnbull, A., Shank, M., Smith, S., \& Leal, D. (2002). Exceptional lives special education in today's school. Ohio: Merrill Prentice Hall.

Türkiye Özürlüler Araştırması İkincil Analiz [Secondary Analysis of Disability Survey in Turkey] (2002). http://www.ozida.gov.tr/arastirma/troailerianaliz.htm adresinden erişilmiştir.

Walsh, D., \& Downe, S. (2005). Meta-synthesis method for qualitative research: a literature review. Journal of Advanced Nursing, 50(2), 204-211.

Wei, X., Blackorby, J., \& Schiller, E. (2011). Growth in reading achievement of students with disabilities, ages 7 to 17. Exceptional Children, 78(1), 89-106.

Wessels, M. D., Bossink, L. W., \& Van Der Putten, A. A. (2017). The effects of a power-assisted exercise intervention on alertness in people with profound intellectual and multiple disabilities. Journal of Cognitive Education and Psychology, 16(3), 281-292. 
In the writing process of the study titled "Review of International Studies on Multiple Disabilities", the rules of scientific, ethical and citation were followed; it was undertaken by the authors of this study that no falsification was made on the collected data. "Sakarya University Journal of Education Journal and Editor" had no responsibility for all ethical violations to be encountered, and all responsibility belongs to the authors and that the study was not submitted for evaluation to any other academic publishing environment. 


\section{Çoklu Yetersizliğe İlişkin Uluslararası Çalışmaların Gözden Geçirilmesi}

\section{Ayten DÜZKANTAR* Damla ALTIN***}

\author{
Kürşat ÖĞÜLMÜŞ ${ }^{* *}$ \\ Bora GÖRGÜN ${ }^{* * * *}$
}

Öz. $\mathrm{Bu}$ çalışmanın amacı ilgili alanyazında çoklu yetersizlikler ile ilgili gerçekleştirilen tüm çalışmaları meta-sentez yöntemi ile gözden geçirerek yeni çalışmalara bakış açısı sağlamaktır. Bu amaçla çoklu yetersizlikler ile ilgili çocuklar, aileler, onlara sunulan hizmetler ve uygulamalarla ilgili tüm çalışmalar ve 20102020 yılları içerisinde dünyada yayımlanan bilimsel çalışmalar taranmıştır. İncelenen uluslararası makalelerin belirlenmesindeki ölçüt, makalelerin hakemli dergilerde yayımlanmış olmasıdır. Tarama 2020 yılı Haziran ayında elektronik veri tabanlarında gerçekleştirilmiştir. Bu taramalarda; ERIC, EBSCO, Topic Search and Primary Search veri tabanları özel eğitim, çok özürlülük, çoklu engel, ileri ve çoklu yetersizlikler gibi anahtar kelimeler kullanılarak taranmıștır. 2010-2020 yılları arasında yapılmış 96 çalışmaya ulaşılmıştır. Özellikle yeni gelişen bir alan olması ve güncel uygulamalara vurgu yapılması amacıyla son on yıl ele alınmıştır. Çalışma kapsamında 96 araştırma incelenmiştir. Ulaşılan makaleler amaç, katılımcl, yöntem, sınırlılıklar, sonuçlar ve öneriler dikkate alınarak incelenmiş ve bulgular kısmında ayrıntılı olarak açıklanmıştır.

Anahtar Kelimeler: Özel eğitim, çoklu yetersizlik, ağır çoklu yetersizlik.

\footnotetext{
* Orcid ID: https://orcid.org/0000-0002-7590-8764, Doç. Dr., Anadolu Üniversitesi, Engelliler Araştırma Enstitüsü, Türkiye, auysal@anadolu.edu.tr

** Orcid ID: https://orcid.org/0000-0001-7551-6894, Dr. Öğr. Üyesi, Kırıkkale Üniversitesi, Özel Eğitim Bölümü, Türkiye, kursatogulmus@hotmail.com

*** Orcid ID: https://orcid.org/0000-0001-8091-7625, Arş. Gör., Sakarya Üniversitesi, Özel Eğitim Bölümü, Türkiye, altin@sakarya.edu.tr

**** Orcid ID: https://orcid.org/0000-0002-9080-5667, Dr. Öğr. Üyesi, İzmir Demokrasi Üniversitesi, Özel Eğitim Bölümü, Türkiye, bboorraagorgun@gmail.com
} 


\section{GİRIŞ}

Çoklu yetersizlik, içinde birçok yetersizliğin birleşimini barındıran şemsiye bir terimdir. Genellikle her bir yetersizlik birbirinin etkisini arttırarak daha fazla yetersizliğin oluşmasına neden olur. Çoklu yetersizliğe sahip bireyler motor becerilerde, bilişsel becerilerde, sosyal becerilerde ve öz bakım becerilerinde yaşadıkları güçlükler sebebiyle bağımsız yaşam sürdürmede ciddi güçlükler yaşamakta ve yaşamları boyunca desteğe gereksinim duymaktadırlar (Orelove ve Sobsey, 1996).

Dünya Sağlık Örgütü (WHO, 1997) çolu yetersizliği, birden fazla yetersizliğe sahip olma durumu ve öğrenmede zorluklar çekilmesi olarak tanımlarken; 2004'te Özürlülerin Eğitimi Kanunu (The Individuals with Disabilities EducationAct (IDEA) eğitsel bakış açısıyla çoklu yetersizliği "birden fazla yetersizliğe sahip olmaları dolayısıyla (örneğin zihinsel yetersizlik + görme yetersizliği, zihinsel yetersizlik + ortopedik yetersizlikler) ileri derecede destek eğitime ihtiyacı olan ve bir yetersizlik türü için oluşturulan özel eğitim programlarının uygulandığı kurumlardan yararlanamama durumu olarak tanımlamaktadır. Özürlülerin Eğitimi Kanunu (IDEA) ileri düzeyde yetersizliği ayrı bir kategoride tanımlamamaktadır. İleri düzeyde yetersizlik ile çoklu yetersizliğin birbirine bitişik kavramlar olduğu ifade edilmektedir (Gargiulo, 2004; Akt. Bahçivanoğlu-Yazıcı, 2009).

Dünya genelinde ve ülkemizde çoklu yetersizliğe sahip birey sayısında artış olduğu kanısı yaygındır. Ancak bu artışın farkındalık ve tanılamanın netleşmesiyle ilgili olduğu düşünülebilir. Bu artışın diğer bir sebebi ise tıbbi teknolojinin ilerlemesi ile birlikte erken doğan ya da sağlık yönünden sorunlu doğan bebeklerin yaşatılma oranının atmasıdır. Ancak bu bebeklerin büyük bir çoğunluğu yaşamlarını bir veya birden fazla yetersizlikle sürdürmek durumunda kalmaktadırlar (Ayyıldız, 2007; Batu ve Kırcaali-İftar, 2005; Chaudhari, Otiv, Chitale, Pandit ve Hoge, 2003; Clark Gerken, 2004; Fazzi ve Pogrund, Çev. Varol, 1996; Gresnight, 2007; Pawletco, 2002). Çoklu yetersizliğe sahip bireylerin yaygınlık oranının, özel eğitime gereksinimi olan bireylerin yaklaşık \%2'si kadar olduğu genel kabul görmektedir (Meyen ve Skrtic, 1995). Genel nüfus oranına göre değerlendirme yapan başka bir kaynağa göre ağır ve çoklu yetersizlik normal nüfus içindeki bireylerin \% 1'i kadardır. Bu oranın yaklaşık \%40'ında ek yetersizlikler vardır (Hardin, 2006; Tam, Phillips ve Mudford, 2011).

$\mathrm{Bu}$ çalışmanın amacı, uluslararası alanda yapılan çoklu yetersizlikler ile ilgili çalışmaları gözden geçirmek, son 10 yılına dayalı analiziyle yapılanları değerlendirerek yeni çalışmalara bakış açısı sağlamaktır. Bu amaçla şu soruların yanıtları aranmıştır. Son dönemde çoklu yetersizlikler ile ilgili çalışmaların daha çok (i) hangi amaçlarla, (ii) hangi yetersizlik gruplarındaki deneklerle, (iii) hangi yöntemler kullanılarak, (iv) ne tür sonuçlara ulaşılmıştır, (v) elde edilen sonuçlara ulaşmada karşılaşılan güçlükler nelerdir ve (vi) bundan sonraki çalışmalar için ne tür önerilerde bulunulmuştur. 


\section{YÖNTEM}

Bu çalışma kapsamında ele alınan araştırmaların bulgularını sentezlemek için nitel araştırma desenlerinden meta-sentez (tematik içerik analizi) kullanılmıştır (Çalık ve Sözbilir, 2014). Meta-sentez çalışmalarında, belirlenen çalışma alanlarında aynı konuyu ele alan çalışmaların bulguları tematik olarak incelenerek çıkarımlarda bulunmak yerine yorumlanır. Meta sentez çalışmalarında somut, algılanabilir ve denenebilir sonuçlara ulaşılmaya çalışılır (Walsh ve Downe, 2005).

\section{Araştırmaların Belirlenmesi}

$\mathrm{Bu}$ çalışmada çoklu yetersizlikler ile ilgili son 10 yılda yapılan çalışmalar değerlendirilmiştir. Çalışma kapsamına alınacak makalelerin belirlenmesinde üç kriter belirlenmiştir. Tüm çalışmalar, (a) çalışma grubunu oluşturan ailelerin çocuklarının veya çalışma grubundaki katılımcıların çoklu yetersizlik durumundan etkilenmiş olmaları, (b) çalışmaların 2010 ile Haziran 2020 yılları arasında yayımlanmış olması, (c) makalelerin hakemli dergilerde yayımlanmış olmasıdır. Çalışma kapsamındaki makalelere ERIC, EBSCO, Topic Search and Primary Search elektronik veri tabanlarında tarama yapılarak ulaşılmıştır. Bu veri tabanlarının tercih edilme nedeni en bilindik ve sık kullanılan veritabanları olmasıdır. Ayrıca çevrimiçi indekslerde yayımlanan dergiler de taranmıştır. Bu taramalarda, belirlenen yıl aralığında "özel eğitim, çok özürlülük, çoklu engel, ileri ve çoklu yetersizlikler" anahtar kelimeleri kullanılmıştır. Taranan 2010-2020 arası yıllarda uluslararası hakemli dergilerde 96 makale belirlenmiştir. Alanyazında yer alan 96 araştırma; amaç, denekler, ortam, yöntem, kullanılan veri toplama araçları ve bulgular dikkate alınarak incelenmiş, tablolaştırılmış ve bulgular kısmında ayrıntılı olarak açıklanmıştır.

\section{Analiz Süreci}

Belirlenen ölçütlere göre yapılan tarama sonucunda ulaşılan makaleler (a) çalışmanın amacı, (b) katılımcı özellikleri, (c) kullanılan yöntem, (d) belirlenen sinırlılıklar, (e) bulgular ve (f) öneriler açısından değerlendirilmiştir. Ayrıca yapılan çalışmalar ülkemizde çoklu yetersizlikler ile ilgili yeni araştırma ve uygulamaları başlatmak üzere fikir vermesi ve yol gösterici olabilmesi için karşılaştırmalı olarak incelenmiştir.

Çalışmaların amaç, denekler, ortam, yöntem, kullanılan veri toplama araçları ve bulgularına ilişkin betimsel özetlemeler iki kişi tarafından yapılmış, tüm makalelerin özetlemeleri birinci yazar tarafından karşılaştırılarak kontrol edilmiştir. Çalışmaların amaç, denekler, ortam, yöntem, kullanılan veri toplama araçları ve bulgularına ilişkin alt kategoriler oluşturularak, kategorilendiriciler arası tutarlılık hesaplaması ile iç güvenirlik çalışması yapılmıştır. Kategorilendiriciler arası uyuşmazlıklarda, değerlendirici ile birlikte alt kategorilere tekrar bakılarak görüş birliği sağlanmıştır. Yapılan çalışmanın güvenirlik hesaplaması "görüş birliği / görüş ayrılığı + görüş birliği x 100" formülü kullanılarak yapılmıştır. Çalışmaların amaçlarına ilişkin \%100; deneklerine ilişkin \%95,7; ortamına ilişkin \%100; yöntemine ilişkin \%100; kullanılan veri toplama araçlarına ilişkin \%91,4 ve bulgularına ilişkin \%95,7 kategorilendiriciler arası güvenirlik belirlenmiştir. 


\section{BULGULAR}

İlgili alanyazında son 10 yılda yapılan çoklu yetersizlikler ile ilgili çalışmaların meta sentezine dayalı değerlendirmelere yer verilerek yeni çalışmalara yönelimin arttırılmasına ve yeni araştırmalar için yeni fikirlerin olgunlaştırılmasına yön verilmeye çalışılmıştır. Alanyazın taramasında belirlenen kriterlere uyan 96 makalenin amacı, katılımcı özellikleri, kullanılan yöntemleri, sınırlılıkları, sonuçları ve önerileri analiz edilerek aşağıdaki bulgulara ulaşılmıştır.

Amaçlarına Göre Araştırma Bulguları: İncelenen 96 makalenin amaçlarına göre sınıflanması Tablo 1'de özetlenmiştir.

Tablo 1

Ele Alınan Çalışmaların Amaçlarına Göre Dağılımları

\begin{tabular}{|c|c|c|c|}
\hline Amaçlar & Yazar & $\mathrm{N}$ & $\%$ \\
\hline $\begin{array}{l}\text { İletişim ve dikkat } \\
\text { becerileri } \\
\text { öğretimi }\end{array}$ & $\begin{array}{l}\text { Boas, Ferreira, Moura, Maia ve Amaral, 2016; Brug, Putten, } \\
\text { Penne, Maes ve Vlaskamp, 2016; Bullen, Luger, Prudhomme } \\
\text { ve Geiger, 2018; Delden, Wintels, Oorsouw, Evers, Embregts, } \\
\text { Heylen ve Reidsma, 2020; Felicio, Seabra-Junior, Rodrigues, } \\
\text { 2019; Frederiks, Sterkenburg, Barakova, Feijs, 2019; } \\
\text { Holmqvist, Derbring ve Wallin, 2017; Holyfield, 2019; } \\
\text { Holyfield, Brooks ve Schluterman, 2019; Johnson ve Parker, } \\
\text { 2013; Kemp, Stephenson, Cooper ve Hodge, 2016; Knapik- } \\
\text { Szweda, 2019; Kumar, 2013; Lancioni, Singh, O’Reilly, } \\
\text { Sigafoos, Resta, Campodonico Alberti ve Chiariello, 2020; } \\
\text { Lancioni, Singh, O’Reilly, Sigafoos, Boccasini, Perilli ve } \\
\text { Spagnuolo, 2017; Lancioni, Singh, O'Reilly, Sigafoos, D’Amico, } \\
\text { Buonocunto, Navarro, Lanzilotti ve Alberti, 2017; Lancioni, } \\
\text { Singh, O’Reilly, Sigafoos, Alberti, Perilli, Boccasini, Martire ve } \\
\text { Zagaria, 2017; Lancioni, Singh, O’Reilly, Green, Meer, Alberti, } \\
\text { Perilli, Boccasini, Martire ve Lang, 2015; Lancioni, Singh, } \\
\text { O’Reilly, Sigafoos, Boccasini, Martire ve Lang, 2014; Lancioni, } \\
\text { Singh, O'Reilly, Sigafoos, Oliva, Alberti ve Buono, 2014; } \\
\text { Lancioni, Bellini, Oliva, Singh, O’Reilly, Lang, Didden ve Bosco, } \\
\text { 2011; Nijs, Vlaskamp ve Maes, 2020; Pilesjö ve Norén, 2017; } \\
\text { Ricci, Miglino, Alberti, Perilli ve Lancioni, 2017. }\end{array}$ & 24 & 25 \\
\hline $\begin{array}{l}\text { Motor } \\
\text { becerilerini } \\
\text { geliștirme/ } \\
\text { değerlendirme }\end{array}$ & $\begin{array}{l}\text { Bossink, Putten, Waninge ve Vlaskamp, 2017; Cunha, Neiva ve } \\
\text { Silva, 2019; Ferreira, Zotz, Melo ve Israel, 2019; } \\
\text { Lancioni, Singh, O’Reilly, Sigafoos, Campodonico, Alberti, } \\
\text { Perilli, Zimbaro, Chiariello ve Campodonico, 2018; Lancioni, } \\
\text { Singh, O’Reilly, Sigafoos, Campodonico, Oliva, Alberti ve } \\
\text { D’amico, 2018; Lancioni, Singh, O'Reilly, Sigafoos, Alberti, } \\
\text { Campodonico, Perilli, Chiariello ve Zimbaro, 2017; Lancioni, } \\
\text { Singh, O’Reilly, Sigafoos, Alberti, Perilli, Zimbaro, Boccasini, } \\
\text { Mazzola ve Russo, 2018; Lancioni, Singh, O'Reilly, Sigafoos, } \\
\text { Alberti, Perilli ve Campodonic, 2017; Lancioni, Singh, O’Reilly, } \\
\text { Sigafoos, Alberti ve Campodonico, 2016; Lancioni, Singh, } \\
\text { O’Reilly, Sigafoos, Oliva, Campodonico, Alberti ve Lang, 2014; } \\
\text { Lancioni, O’Reilly, Singh, Green, Oliva, Campodonico, Lang ve } \\
\text { Buono, 2013; Lancioni, O’Reilly, Singh, Sigafoos, Oliva, } \\
\text { Campodonico ve Lang, 2012; Shih, 2012; Neagu ve Zsuzsanna, } \\
\text { 2020; Stasolla, Caffo, Perilli, Boccasini, Stella, Damiani, Albano } \\
\text { ve Damato, 2017; Wessels, Bossink ve Putten, 2017. }\end{array}$ & 16 & 16.66 \\
\hline
\end{tabular}




\begin{tabular}{ll}
\hline Teknoloji & Argyropoulos ve Thymakis, 2014; Desideri, Bizzarri, Bitelli, \\
kullanımı & Roentgen, Gelderblom ve Witte, 2016; Holyfield, Light, \\
ögretimi & Drager, McNaughton ve Gormley, 2018; Shih, 2014; Shih, \\
& 2013; Lancioni, Singh, O’Reilly, Sigafoos, Campodonico, \\
& Zimbaro, Alberti, Trubia ve Zagaria, 2018; Lancioni, O’Reilly, \\
& Sigafoos, Campodonico Perilli, Alberti, Ricci ve Miglino, 2017; \\
& Lancioni, Singh, O’Reilly, Sigafoos, Campodonico ve Alberti, \\
& 2017; Lancioni, O'Reilly, Singh, Sigafoos, Boccasini, Martire, \\
& Perilli, Spagnuolo, 2016; Lancioni, Singh, O’Reilly, Sigafoos, \\
& Boccasini, Martire ve Smaldone, 2016; Lancioni, O’Reilly, \\
& Singh, Green, Oliva, Buonocunto, Colonna ve Navarro, 2012; \\
& Lancioni, Singh, O'Reilly, Sigafoos, Oliva, Signorino ve \\
& Tommaso, 2010; Moir, 2010; Shih, 2011; Shih, Cheng, Li, Shih \\
& ve Chiang, 2010; Shih, Shih ve Wang, 2010.
\end{tabular}

\begin{tabular}{lll}
\hline Günlük yaşam & Axelsson, Granlund ve Wilder, 2013; Benford, 2017; Eldeniz & 11 \\
becerileri & ve Bozak, 2020; Dayl ve Şafak, 2018; Hanzen, Nispen, & \\
öğretimi & Vlaskamp, Korevaar, Waninge ve Putten, 2020; Ivy, Hatton ve & \\
& Wehby, 2018; Janssen, Brink-Groenendijk, Riksen-Walraven, \\
& Huisman, Dijkve Ruijssenaars, 2014; Lancioni, Singh, O’Reilly, \\
& Sigafoos, Alberti, Chiariello ve Carrella, 2020; Lancioni, Singh, \\
& O’Reilly, Sigafoos, Alberti, Zimbaro ve Chiariello, 2017; \\
& Lancioni, Singh, O’Reilly, Sigafoos, Boccasini, Alberti ve Lang, \\
& 2014; Lancioni, Singh, O'Reilly, Sigafoos, Boccasini, Martire, \\
& Oliva ve Lang, 2014.
\end{tabular}

\begin{tabular}{|c|c|c|c|}
\hline $\begin{array}{l}\text { Problem } \\
\text { davranışlarla baş } \\
\text { etme }\end{array}$ & $\begin{array}{l}\text { Bosch, Andringa, Peterson, Ruijssenaars ve Vlaskamp, 2017; } \\
\text { Desrochers, Oshlag ve Kennelly, 2014; Lancioni, Singh, } \\
\text { O'Reilly, Green, Oliva ve Campodonico, 2013; Poppes, Putten } \\
\text { ve Vlaskamp, 2014; Lancioni, O’Reilly, Singh, Sigafoos, Oliva, } \\
\text { Alberti, Carrella, Didden ve Lang, 2013; Poppes, Putten, Frans, } \\
\text { Brug ve Vlaskamp, 2016, Sadler, 2019. }\end{array}$ & 6 & 6,25 \\
\hline $\begin{array}{l}\text { Okuma-yazma/ } \\
\text { matematik } \\
\text { öğretimi }\end{array}$ & $\begin{array}{l}\text { Holyfield, Caron, Light ve McNaughton, 2019; Hudson, } \\
\text { Zambone ve Brickhouse, 2016; Jongbloed-Pereboom, Peeters, } \\
\text { Overvelde, Sanden ve Steenbergen, 2015; Ramani, Police ve } \\
\text { Jacob, 2014; Wei, Blackorby ve Schiller, } 2011 .\end{array}$ & 5 & 5,20 \\
\hline $\begin{array}{l}\text { Program/ } \\
\text { uygulama } \\
\text { hazirlama ve } \\
\text { uyarlama }\end{array}$ & $\begin{array}{l}\text { Depountis, Okungu ve Molloy-Daugherty, 2019; Mechling ve } \\
\text { Bishop, 2011; Taylor ve Preece, } 2010 .\end{array}$ & 3 & 3.12 \\
\hline $\begin{array}{l}\text { Boş zaman } \\
\text { değerlendirme }\end{array}$ & $\begin{array}{l}\text { Lancioni, Singh, O’Reilly, Sigafoos, Belardinelli, Buonocunto, } \\
\text { D’Amico, Navarro, Lanzilotti, Denitto, Tommaso ve Megna, } \\
\text { 2015; Lancioni, Singh, O'Reilly, Green, Oliva, Buonocunto, } \\
\text { Sacco, Biancardi ve Di Nuovo, 2012; Lancioni, O’Reilly, Singh, } \\
\text { Sigafoos, Alberti, Boccasini, Oliva ve Lang, } 2014 \text {. }\end{array}$ & 3 & 3,12 \\
\hline $\begin{array}{l}\text { Görüş } \\
\text { belirlenmesi }\end{array}$ & Hostyn ve Maes, 2013 & 2 & 2.08 \\
\hline $\begin{array}{l}\text { Kendini yönetme } \\
\text { becerileri }\end{array}$ & $\begin{array}{l}\text { Shogren, Kennedy, Dowsett ve Little, 2014; Munde ve } \\
\text { Vlaskamp, 2014. }\end{array}$ & 2 & 2,08 \\
\hline İş̧ eğitimi & Lancioni, Singh, O’Reilly, Green, Oliva ve Campodonico, 2013. & 1 & 1.04 \\
\hline $\begin{array}{l}\text { Biyolojik } \\
\text { fonksiyonlar }\end{array}$ & Blain-Moraes ve Chau, 2012 & 1 & 1.04 \\
\hline $\begin{array}{l}\text { Öğrenci/ } \\
\text { uygulamacl } \\
\text { değerlendirme, } \\
\text { görüș belirleme }\end{array}$ & Krämer ve Zentel, 2020 & 1 & 1.04 \\
\hline
\end{tabular}




\begin{tabular}{|c|c|c|c|}
\hline Sembol öğretimi & Trief, Cascella ve Bruce, 2013. & 1 & 1.04 \\
\hline Oyun öğretimi & Ferreira, Travassos, Alves, Sampaio ve Pereira-Guizzo, 2013. & 1 & 1.04 \\
\hline $\begin{array}{l}\text { Kaygı düzeyini } \\
\text { değerlendirme }\end{array}$ & Nelson, Greenfield, Hyte ve Shaffer, 2013. & 1 & 1.04 \\
\hline Uyaran tepkisi & Munde, Vlakamp, Maes ve Ruijssenaars, 2012. & 1 & 1.04 \\
\hline Tuvalet eğitimi & Chang, Lee, Chou, Chen ve Chen, 2011. & 1 & 1.04 \\
\hline
\end{tabular}

Yapılan çalışmaların \%25'inin iletişim becerilerinin öğretilmesi amacıyla yapıldı̆̆ı belirlenmiştir. Çoklu yetersizliği olan bireylerin pek çoğu dil gelişimindeki sınırlılık nedeniyle, çevresindeki kişilerle iletişim kurma açısından çok önemli sıkıntılar yaşamaktadır (Akçamete, 1992; Chen, 2004; Hourcade, Pilotte, West ve Parette, 2004). Nakken ve Vlaskamp (2007) ise çoklu yetersizliği olan bireylerde sözel dilin anlaşılırlı̆̆ının çok az olduğunu ya da hiç olmadığını, objelerle sembolik etkileşimin de neredeyse hiç olmadığını belirtmiştir. Yapılan çalışmaların \%16'sı teknoloji destekli çalışmalardır. Bu çalışmaların bir kısmında yazma hızı teknoloji desteğiyle arttırılmıştır. $\mathrm{Bu}$ çalışmalara detaylı bakıldığında var olan teknolojik araçların (uyarlanmış ekran, klavye, fare) kullanımını sağlamak üzere yapılmış uyarlamaların işlevselliğini değerlendirme amacı ile yapıldığı belirlenmiştir.

Çalışmaların \%16’sı motor becerilerin geliştirilmesini hedefleyen çalışmalardır. Çoklu yetersizliğe sahip bireylerin fiziksel ve kas gelişimlerinde genellikle sorun vardır. $\mathrm{Bu}$ sorunların başında çocukların kaslarının ya çok kasılması ya da fazla gevşek olması gelmektedir. Büyük ve küçük kaslarının bu özellikleri nedeniyle günlük bazı temel fonksiyonlarını yerine getirmekte güçlük yaşamakta, hareket etme, desteksiz oturma, ayakta durma, yürüme, ellerini ve kollarını hareket ettirme, tutma, kavrama, doğal yollardan beslenme gibi gelişimsel becerileri sergileyemeyebilmektedirler (Kirk, Gallager, Anastasiow ve Coleman 2006; Petitpierre, Wolf, Benz, Adler, 2007; Petry ve Meas, 2007; Şafak, 2012).

Çalışmaların \%11'i günlük yaşam becerisi öğretimiyle ilgilidir. Ağır düzeyde fiziksel problemleri olan çoklu yetersizliğe sahip bireyler günlük bakımlarında genellikle bakıcılarına bağımlı kalırlar. Çünkü bağımsız yaşam ve özbakım aktivitelerinin büyük çoğunluğunda desteğe ve bu becerileri kazanabilmeleri için yaşam boyu eğitime ihtiyaçları vardır (Hostyn, 2011; Meyen ve Skrtic, 1995; Vlaskamp ve Putten, 2009). Okuma yazma öğretimini hedefleyen (\%5) beş çalışma vardır. Bir çalışmada yazma becerisi çoklu ve ileri düzeyde yetersizliğe sahip katılımcılara klavye kullanılarak teknoloji destekli öğretilmiştir. İncelenen çalışmalarda boş zaman etkinliklerinin öğretiminin \%4 oranında olduğu, öncelikle işlevsel becerilerin öğretimine ağırlık verildiği görülmektedir. İleri düzeyde ve çoklu yetersizliği olan çocukların, onlara sistematik şekilde öğretilmedikçe uygun boş zaman etkinliklerini kendi başlarına öğrenemedikleri görülmektedir (Tekin-İftar, 2000). Bu yüzden, ileri ve çoklu yetersizliği olan bireyere 
uygun eğlence ve boş zaman aktiviteleri geliştirmek, önemli bir amaç ve eğitimlerinin bir parçası olarak görülmelidir (Westling ve Fox, 2000).

Katılımcılara Göre Araştırma Bulguları: İncelenen 96 makalenin katılımcılara göre sınıflanması Tablo 2'te özetlenmiştir.

Tablo 2

\section{Ele Alınan Çalışmaların Katılımcılara Göre Dağılımları}

\begin{tabular}{|c|c|c|c|}
\hline Katılımcılar & Yazar & $\mathrm{n}$ & $\%$ \\
\hline $\begin{array}{l}\text { Çoklu } \\
\text { yetersizliğe } \\
\text { sahip çocuk }\end{array}$ & $\begin{array}{l}\text { Boas, Ferreira, Moura, Maia ve Amaral, 2016; Bosch, Andringa, } \\
\text { Peterson, Ruijssenaars ve Vlaskamp, 2017; Bossink, Putten, } \\
\text { Waninge ve Vlaskamp, 2017; Brug, Putten, Penne, Maes ve } \\
\text { Vlaskamp, 2016; Bullen, Luger, Prudhomme ve Geiger, 2018; } \\
\text { Depountis, Okungu ve Molloy-Daugherty, 2019; Desideri, } \\
\text { Bizzarri, Bitelli, Roentgen, Gelderblom ve Witte, 2016; Eldeniz } \\
\text { ve Bozak, 2020; Felicio, Seabra-Junior, Rodrigues, 2019; } \\
\text { Holyfield, Light, Drager, McNaughton ve Gormley, 2018; } \\
\text { Holyfield, 2019; Holyfield, Brooks ve Schluterman, 2019; } \\
\text { Holyfield, Caron, Light ve McNaughton, 2019; Hudson, } \\
\text { Zambone ve Brickhouse, 2016; Ivy, Hatton ve Wehby, 2018; } \\
\text { Knapik-Szweda, 2019; Lancioni, Singh, O’Reilly, Green, Meer, } \\
\text { Alberti, Perilli, Boccasini, Martire ve Lang, 2015; Lancioni, } \\
\text { Singh, O'Reilly, Sigafoos, Belardinelli, Buonocunto, D’Amico, } \\
\text { Navarro, Lanzilotti, Denitto, Tommaso ve Megna, 2015; Shih, } \\
\text { 2014; Janssen, Brink-Groenendijk, Riksen-Walraven, Huisman, } \\
\text { Dijk ve Ruijssenaars, 2014; Lancioni, Singh, O'Reilly, Sigafoos, } \\
\text { Boccasini, Alberti ve Lang, 2014; Shogren, Kennedy, Dowsett ve } \\
\text { Little, 2014; Lancioni, Singh, O’Reilly, Sigafoos, Oliva, } \\
\text { Campodonico, Alberti ve Lang, 2014; Lancioni, Singh, O'Reilly, } \\
\text { Sigafoos, Boccasini, Martire ve Lang, 2014; Lancioni, O’Reilly, } \\
\text { Singh, Sigafoos, Alberti, Boccasini, Oliva ve Lang, 2014; Hostyn } \\
\text { ve Maes, 2013; Shih, 2013; Lancioni, Singh, O’Reilly, Green, } \\
\text { Oliva ve Campodonico, 2013; Lancioni, O’Reilly, Singh, } \\
\text { Sigafoos, Oliva, Alberti, Carrella, Didden ve Lang, 2013; } \\
\text { Lancioni, O’Reilly, Singh, Green, Oliva, Buonocunto, Colonna ve } \\
\text { Navarro, 2012; Blain-Moraes ve Chau, 2012; Lancioni, Singh, } \\
\text { O’Reilly, Green, Oliva, Buonocunto, Sacco, Biancardi ve Di } \\
\text { Nuovo, 2012; Shih, 2011; Shih, 2012; Shih, Cheng, Li, Shih ve } \\
\text { Chiang, 2010; Lancioni, Singh, O’Reilly, Sigafoos, Oliva, } \\
\text { Signorino ve Tommaso, 2010; Shih, Shih ve Wang, 2010; Neagu } \\
\text { ve Zsuzsanna, 2020; Pilesjö ve Norén, 2017. Sadler, 2019; } \\
\text { Stasolla, Caffo, Perilli, Boccasini, Stella, Damiani, Albano ve } \\
\text { Damato, 2017. }\end{array}$ & 40 & 42.55 \\
\hline $\begin{array}{l}\text { Çoklu } \\
\text { yetersizlğe } \\
\text { sahip yetişkin }\end{array}$ & $\begin{array}{l}\text { Benford, 2017; Cunha, Neiva ve Silva, 2019; Delden, Wintels, } \\
\text { Oorsouw, Evers, Embregts, Heylen ve Reidsma, 2020; Ferreira, } \\
\text { Zotz, Melo ve Israel 2019; Frederiks, Sterkenburg, Barakova, } \\
\text { Feijs, 2019; Jongbloed-Pereboom, Peeters, Overvelde, Sanden } \\
\text { ve Steenbergen, 2015; Krämer ve Zentel, 2020; Lancioni, Singh, } \\
\text { O’Reilly, Sigafoos, Campodonico, Zimbaro, Alberti, Trubia ve } \\
\text { Zagaria, 2018; Lancioni, Singh, O'Reilly, Sigafoos, Alberti, } \\
\text { Perilli, Zimbaro, Boccasini, Mazzola ve Russo, 2018; Lancioni, } \\
\text { Singh, O’Reilly, Sigafoos, Alberti, Chiariello ve Carrella, 2020; } \\
\text { Lancioni, Singh, O'Reilly, Sigafoos, Campodonico, Alberti, } \\
\text { Perilli, Zimbaro, Chiariello ve Campodonico, 2018; Lancioni, } \\
\text { Singh, O'Reilly, Sigafoos, Boccasini, Perilli ve Spagnuolo, 2017; }\end{array}$ & 34 & 36.17 \\
\hline
\end{tabular}


Lancioni, Singh, O’Reilly, Sigafoos, Alberti, Campodonico, Perilli, Chiariello ve Zimbaro, 2017; Lancioni, Singh, O’Reilly, Sigafoos, Alberti, Zimbaro ve Chiariello, 2017; Lancioni, O’Reilly, Sigafoos, Campodonico Perilli, Alberti, Ricci ve Miglino, 2017; Lancioni, Singh, O’Reilly, Sigafoos, Alberti, Perilli ve Campodonic, 2017;

Lancioni, Singh, O’Reilly, Sigafoos, Alberti, Perilli, Boccasini, Martire ve Zagaria, 2017; Lancioni, Singh, O’Reilly, Sigafoos, D’Amico, Buonocunto, Navarro, Lanzilotti ve Alberti, 2017; Lancioni, Singh, O’Reilly, Sigafoos, Campodonico ve Alberti, 2017; Lancioni, Singh, O'Reilly, Sigafoos, Alberti ve Campodonico, 2016; Lancioni, O’Reilly, Singh, Sigafoos, Boccasini, Martire, Perilli, Spagnuolo, 2016; Lancioni, Singh, O’Reilly, Sigafoos, Boccasini, Martire ve Smaldone, 2016; Lancioni, O’Reilly, Singh, Green, Oliva, Campodonico, Lang ve Buono, 2013; Poppes, Putten ve Vlaskamp, 2014; Desrochers, Oshlag ve Kennelly, 2014; Lancioni, Singh, O'Reilly, Sigafoos, Boccasini, Martire, Oliva ve Lang, 2014; Argyropoulos ve Thymakis, 2014; Munde ve Vlaskamp, 2014; Trief, Cascella ve Bruce, 2013; Johnson ve Parker, 2013; Ferreira, Travassos, Alves, Sampaio ve Pereira-Guizzo, 2013; Nelson, Greenfield, Hyte ve Shaffer, 2013; Chang, Lee, Chou, Chen ve Chen, 2011; Mechling ve Bishop, 2011.

Karma (Çoklu Dayı ve Şafak, 2018; Holmqvist, Derbring ve Wallin, 2017;

yetersizlğe Lancioni, Singh, O’Reilly, Sigafoos, Resta, Campodonico Alberti sahip çocuk ve yetişkin) ve Chiariello, 2020; Lancioni, Singh, O’Reilly, Sigafoos, Campodonico, Oliva, Alberti ve D’amico, 2018; Lancioni, Singh, O'Reilly, Sigafoos, Oliva, Alberti ve Buono, 2014; Munde, Vlakamp, Maes ve Ruijssenaars, 2012; Lancioni, O’Reilly, Singh, Sigafoos, Oliva, Campodonico ve Lang, 2012; Ramani, Police ve Jacob, 2014; Lancioni, Bellini, Oliva, Singh, O’Reilly, Lang, Didden ve Bosco, 2011; Nijs, Vlaskamp ve Maes, 2020; Ricci, Miglino, Alberti, Perilli ve Lancioni, 2017; Taylor ve Preece, 2010; Wei, Blackorby ve Schiller, 2011; Wessels, Bossink ve Putten, 2017.

\begin{tabular}{|c|c|c|c|}
\hline $\begin{array}{l}\text { Erken } \\
\text { çocukluk } \\
\text { dönemi }\end{array}$ & $\begin{array}{l}\text { Kemp, Stephenson, Cooper ve Hodge, 2016; Kumar, 2013; Moir, } \\
2010 .\end{array}$ & 3 & 3.19 \\
\hline $\begin{array}{l}\text { Öğretmen/ } \\
\text { Terapist }\end{array}$ & $\begin{array}{l}\text { Hanzen, Nispen, Vlaskamp, Korevaar, Waninge ve Putten, } \\
\text { 2020; Poppes, Putten, Frans, Brug ve Vlaskamp, 2016; }\end{array}$ & 2 & 2.12 \\
\hline
\end{tabular}

Ebeveyn $\quad$ Axelsson, Granlund ve Wilder, 2013.

1.06

Özel eğitimde erkenlik ilkesine uyularak çoklu ve ileri düzeyde yetersizliğe sahip bireylerde de yetersizliğin engele dönüşmeden ve kalıcı hale gelmeden eğitim çalışmalarına yer verilmiş olduğu \%42.55 oranındaki çalışmanın çocuklarla yapılmasından anlaşılmaktadır. Bazı çalışmalarda (\%14.89) farklı yaşlardaki katılımcılara aynı becerilerin öğretiminin yapıldığı gözlenmiştir. Erken çocukluk (\%3.19) yapılan çalışmaların az olduğu dikkat çekicidir. Bu durum çoklu ve ileri düzeyde yetersizliğe sahip bireylerin nüfus içindeki sayısıyla uyumludur. Ağır ve çoklu yetersizliğin normal nüfus 
içindeki bireylerin \% 1'i olduğu bilinmektedir (Hardin, 2006; Tam, Phillips ve Mudford, 2011).

Çalışmaların \%36.17'sinin çoklu ve ileri düzeyde yetersizliğe sahip yetişkin grubuna yönelik yapılmış olması eğitim ve sağaltım desteğinin son yıllarda geliştiğinin göstergesi olarak da algılanabilir. Çünkü çoklu yetersizliğe sahip bireylerin, özel eğitime gereksinimi olan bireylerin yaklaşık \%2'si kadar olduğu bilinmektedir (Meyen ve Skrtic, 1995). Eğitim olanakları gelişene kadar üst yaş gruplarında eğitim almamış birey sayısının daha fazla olduğu düşünüldüğünde çalışmalarda onlara yönelik araştırmaların fazla olması bir gereklilik olarak düşünülmelidir.

Genel nüfus içindeki oranına göre değerlendirme yapıldığında ağır ve çoklu yetersizliğe sahip bireyler ve onların birincil bakıcıları ile birlikte oldukça geniş bir kitlenin gereksinim ve görüşlerinin belirlenmesi bir gereksinim olarak düşünülmelidir.

Yöntemine Göre Araştırma Bulguları: İncelenen 96 makalenin yönteme göre sınıflanması Tablo 3'te özetlenmiștir.

Tablo 3

\section{Ele Alınan Çalışmaların Yöntemine Göre Dağılımları}

\begin{tabular}{|c|c|c|c|}
\hline Yöntem & Yazar & $\mathrm{n}$ & $\%$ \\
\hline $\begin{array}{l}\text { Tek Denekli } \\
\text { Modeller }\end{array}$ & $\begin{array}{l}\text { Cunha, Neiva ve Silva, 2019; Dayl ve Şafak, 2018; Delden, Wintels, } \\
\text { Oorsouw, Evers, Embregts, Heylen ve Reidsma, 2020; Eldeniz ve } \\
\text { Bozak, 2020; Felicio, Seabra-Junior, Rodrigues, 2019; Frederiks, } \\
\text { Sterkenburg, Barakova, Feijs, 2019; Holyfield, 2019; Holyfield, } \\
\text { Brooks ve Schluterman, 2019; Holyfield, Caron, Light ve } \\
\text { McNaughton, 2019; Hudson, Zambone ve Brickhouse, 2016; Ivy, } \\
\text { Hatton ve Wehby, 2018; Kemp, Stephenson, Cooper ve Hodge, } \\
\text { 2016; Lancioni, Singh, O’Reilly, Sigafoos, Campodonico, Zimbaro, } \\
\text { Alberti, Trubia ve Zagaria, 2018; Lancioni, Singh, O’Reilly, } \\
\text { Sigafoos, Alberti, Chiariello ve Carrella, 2020; Lancioni, Singh, } \\
\text { O’Reilly, Sigafoos, Resta, Campodonico Alberti ve Chiariello, } \\
\text { 2020; Lancioni, Singh, O’Reilly, Sigafoos, Campodonico, Alberti, } \\
\text { Perilli, Zimbaro, Chiariello ve Campodonico, 2018; Lancioni, } \\
\text { Singh, O'Reilly, Sigafoos, Campodonico, Oliva, Alberti ve D'amico, } \\
\text { 2018; Lancioni, Singh, O’Reilly, Sigafoos, Boccasini, Perilli ve } \\
\text { Spagnuolo, 2017; Lancioni, Singh, O’Reilly, Sigafoos, Alberti, } \\
\text { Campodonico, Perilli, Chiariello ve Zimbaro, 2017; Lancioni, } \\
\text { Singh, O’Reilly, Sigafoos, Alberti, Zimbaro ve Chiariello, 2017; } \\
\text { Lancioni, Singh, O’Reilly, Sigafoos, D’Amico, Buonocunto, } \\
\text { Navarro, Lanzilotti ve Alberti, 2017;Lancioni, Singh, O’Reilly, } \\
\text { Sigafoos, Alberti, Perilli ve Campodonic, 2017; Lancioni, O’Reilly, } \\
\text { Sigafoos, Campodonico Perilli, Alberti, Ricci ve Miglino, 2017; } \\
\text { Lancioni, Singh, O’Reilly, Sigafoos, Campodonico ve Alberti, 2017; } \\
\text { Lancioni, Singh, O’Reilly, Sigafoos, Alberti, Perilli, Boccasini, } \\
\text { Martire ve Zagaria, 2017;Lancioni, Singh, O’Reilly, Sigafoos, } \\
\text { Alberti ve Campodonico, 2016; Lancioni, O’Reilly, Singh, Sigafoos, } \\
\text { Boccasini, Martire, Perilli, Spagnuolo, 2016; Lancioni, Singh, } \\
\text { O’Reilly, Sigafoos, Boccasini, Martire ve Smaldone, 2016; } \\
\text { Lancioni, Singh, O’Reilly, Green, Meer, Alberti, Perilli, Boccasini, } \\
\text { Martire ve Lang, 2015; Lancioni, O’Reilly, Singh, Green, Oliva, } \\
\text { Campodonico, Lang ve Buono, 2013; Lancioni, Singh, O’Reilly, } \\
\text { Sigafoos, Belardinelli, Buonocunto, D’Amico, Navarro, Lanzilotti, }\end{array}$ & 64 & 66.66 \\
\hline
\end{tabular}


Denitto, Tommaso ve Megna, 2015; Shih, 2014; Lancioni, Singh, O’Reilly, Sigafoos, Oliva, Alberti ve Buono, 2014; Lancioni, Singh, O'Reilly, Sigafoos, Boccasini, Alberti ve Lang, 2014; Desrochers, Oshlag ve Kennelly, 2014; Lancioni, Singh, O’Reilly, Sigafoos, Oliva, Campodonico, Alberti ve Lang, 2014; Lancioni, Singh, O'Reilly, Sigafoos, Boccasini, Martire, Oliva ve Lang, 2014; Lancioni, Singh, O’Reilly, Sigafoos, Boccasini, Martire ve Lang, 2014; Lancioni, O’Reilly, Singh, Sigafoos, Alberti, Boccasini, Oliva ve Lang, 2014; Shih, 2013; Trief, Cascella ve Bruce, 2013; Lancionı, Singh, O’Reilly, Green, Oliva ve Campodonico, 2013; Lancioni, O'Reilly, Singh, Sigafoos, Oliva, Alberti, Carrella, Didden ve Lang, 2013; Johnson ve Parker, 2013; Nelson, Greenfield, Hyte ve Shaffer, 2013; Shih, 2012; Lancioni, O’Reilly, Singh, Sigafoos, Oliva, Campodonico ve Lang, 2012; Lancioni, O’Reilly, Singh, Green, Oliva, Buonocunto, Colonna ve Navarro, 2012; BlainMoraes ve Chau, 2012; Ramani, Police ve Jacob, 2014; Lancioni, Singh, O'Reilly, Green, Oliva, Buonocunto, Sacco, Biancardi ve Di Nuovo, 2012; Lancioni, Bellini, Oliva, Singh, O’Reilly, Lang, Didden ve Bosco, 2011; Chang, Lee, Chou, Chen ve Chen, 2011; Mechling ve Bishop, 2011; Shih, 2011; Shih, Cheng, Li, Shih ve Chiang, 2010; Nijs, Vlaskamp ve Maes, 2020; Taylor ve Preece, 2010; Moir, 2010; Shih, Shih ve Wang, 2010; Lancioni, Singh, O’Reilly, Sigafoos, Oliva, Signorino ve Tommaso, 2010; Ricci, Miglino, Alberti, Perilli ve Lancioni, 2017; Sadler, 2019; Stasolla, Caffo, Perilli, Boccasini, Stella, Damiani, Albano ve Damato, 2017.

Nicel Benford, 2017; Bosch, Andringa, Peterson, Ruijssenaars ve Vlaskamp, 2017; Bossink, Putten, Waninge ve Vlaskamp, 2017; Brug, Putten, Penne, Maes ve Vlaskamp, 2016; Bullen, Luger, Prudhomme ve Geiger, 2018; Depountis, Okungu ve MolloyDaugherty, 2019; Desideri, Bizzarri, Bitelli, Roentgen, Gelderblom ve Witte, 2016; Ferreira, Zotz, Melo ve Israel 2019; Holyfield, Light, Drager, McNaughton ve Gormley, 2018; Krämer ve Zentel, 2020; Lancioni, Singh, O’Reilly, Sigafoos, Alberti, Perilli, Zimbaro, Boccasini, Mazzola ve Russo, 2018; Jongbloed-Pereboom, Peeters, Overvelde, Sanden ve Steenbergen, 2015; Shogren, Kennedy, Dowsett ve Little, 2014; Lancioni, Singh, O'Reilly, Sigafoos, Boccasini, Martire, Oliva ve Lang, 2014; Axelsson, Granlund ve Wilder, 2013; Neagu ve Zsuzsanna, 2020; Poppes, Putten, Frans, Brug ve Vlaskamp, 2016; Wessels, Bossink ve Putten, 2017.

\begin{tabular}{|c|c|c|c|}
\hline Nitel & $\begin{array}{l}\text { Boas, Ferreira, Moura, Maia ve Amaral, 2016; Ferreira, Travassos, } \\
\text { Alves, Sampaio ve Pereira-Guizzo, 2013; Hanzen, Nispen, } \\
\text { Vlaskamp, Korevaar, Waninge ve Putten, 2020; Holmqvist, } \\
\text { Derbring ve Wallin, 2017; Janssen, Brink-Groenendijk, Riksen- } \\
\text { Walraven, Huisman, Dijk ve Ruijssenaars, 2014; Munde, Vlakamp, } \\
\text { Maes ve Ruijssenaars, 2012; Munde ve Vlaskamp, 2014; Pilesjö ve } \\
\text { Norén, 2017; Wei, Blackorby ve Schiller, 2011. }\end{array}$ & 9 & 9.37 \\
\hline $\begin{array}{l}\text { Vaka } \\
\text { Çalışması }\end{array}$ & Hostyn ve Maes, 2013; Knapik-Szweda, 2019; Kumar, 2013. & 3 & 3.31 \\
\hline $\begin{array}{l}\text { Doküman } \\
\text { Analizi }\end{array}$ & Poppes, Putten ve Vlaskamp, 2014 & 1 & 1.04 \\
\hline $\begin{array}{l}\text { Eylem } \\
\text { Araștırmas }\end{array}$ & Argyropoulos ve Thymakis, 2014 & 1 & 1.04 \\
\hline
\end{tabular}

Ele alınan çalışmaların çoğunun (\%66.66) tek denekli araştırma yöntemleri ile yürütülmesi, çoklu ve ileri düzeyde yetersizliğe sahip bireylerin çok farklı özellik ve yeterliklere sahip olması ve grup deneysel çalışmaların desenlenmesi güçlüğünden 
kaynaklanmaktadır. Ayrıca etkili uygulama arayışının aynı zamanda öncelikle işlevsel çalışmalar biçiminde düşünülmesindendir. Çalışmaların \%18.75'inin Nicel olması önceki yapılan çalışmaların karşılaştırılması ve standardizasyonuna ilişkin çalışmaların varlığını göstermektedir. İleri düzeyde yetersizliğe sahip bireylerde detaylı ve derinlemesine bilgi birikiminin oluşturulma gereksiniminin sürüyor olması nitel (\%9.37) çalışmaların da sürdürülmesini gerekli kılmaktadır. \% 3.31'inin vaka çalışması, \%1.04'ünün eylem çalışması olması da ileri düzeyde yetersizliğe sahip çok farklı bireyler için çözüm arayışlarının başlatılmış olduğu anlamında yorumlanabilir. Çalışmaların \% 1.04'ünün döküman analizi olması önceki uygulamalara ilişkin kayıtların analizine dayalı yeni ve etkin uygulamaların tasarlamaya çalışıldığını göstermektedir.

Sinırlılıklarına Göre Araştırma Bulguları: İncelenen 96 makalenin sınırlılıklarına göre sınıflanması Tablo 4'te özetlenmiştir.

Tablo 4

\section{Ele Alınan Çalıșmaların Sınırlılıklarına Göre Dağılımları}

\begin{tabular}{|c|c|c|c|}
\hline Sinırlılıklar & Yazar & $\mathrm{n}$ & $\%$ \\
\hline $\begin{array}{l}\text { Katılımcılar ile } \\
\text { ilgili sinırlılıklar }\end{array}$ & $\begin{array}{l}\text { Argyropoulos ve Thymakis, 2014; Axelsson, Granlund ve } \\
\text { Wilder, 2013; Bosch, Andringa, Peterson, Ruijssenaars } \\
\text { ve Vlaskamp, 2017; Bossink, Putten, Waninge ve } \\
\text { Vlaskamp, 2017; Brug, Putten, Penne, Maes ve Vlaskamp, } \\
\text { 2016; Desrochers, Oshlag ve Kennelly, 2014; Depountis, } \\
\text { Okungu ve Molloy-Daugherty, 2019; Ferreira, Zotz, Melo } \\
\text { ve Israel 2019; Holyfield, 2019; Holyfield, Brooks ve } \\
\text { Schluterman, 2019; Holyfield, Caron, Light ve } \\
\text { McNaughton, 2019; Hudson, Zambone ve Brickhouse, } \\
\text { 2016; Johnson ve Parker, 2013; Lancioni, Singh, O’Reilly, } \\
\text { Sigafoos, Campodonico, Zimbaro, Alberti, Trubia ve } \\
\text { Zagaria, 2018; Lancioni, Singh, O’Reilly, Sigafoos, } \\
\text { Boccasini, Perilli ve Spagnuolo, 2017; Lancioni, Singh, } \\
\text { O’Reilly, Sigafoos, Alberti, Chiariello ve Carrella, 2020; } \\
\text { Lancioni, Singh, O’Reilly, Sigafoos, Resta, Campodonico } \\
\text { Alberti ve Chiariello, 2020; Lancioni, Singh, O’Reilly, } \\
\text { Sigafoos, Campodonico, Alberti, Perilli, Zimbaro, } \\
\text { Chiariello ve Campodonico, 2018; Lancioni, Singh, } \\
\text { O’Reilly, Sigafoos, Campodonico, Oliva, Alberti ve } \\
\text { D’amico, 2018; Lancioni, Singh, O’Reilly, Sigafoos, } \\
\text { Alberti, Campodonico, Perilli, Chiariello ve Zimbaro, } \\
\text { 2017; Lancioni, Singh, O’Reilly, Sigafoos, Alberti, } \\
\text { Zimbaro ve Chiariello, 2017; Lancioni, Singh, O’Reilly, } \\
\text { Sigafoos, Alberti, Perilli ve Campodonic, 2017; Lancioni, } \\
\text { Singh, O’Reilly, Sigafoos, D'Amico, Buonocunto, Navarro, } \\
\text { Lanzilotti ve Alberti, 2017; Lancioni, O’Reilly, Sigafoos, } \\
\text { Campodonico Perilli, Alberti, Ricci ve Miglino, 2017; } \\
\text { Lancioni, Singh, O’Reilly, Sigafoos, Campodonico ve } \\
\text { Alberti, 2017; Lancioni, Singh, O’Reilly, Sigafoos, } \\
\text { Boccasini, Martire ve Smaldone, 2016; Lancioni, Singh, } \\
\text { O’Reilly, Green, Oliva ve Campodonico, 2013; Lancioni, } \\
\text { Singh, O’Reilly, Sigafoos, Oliva, Campodonico, Alberti ve } \\
\text { Lang, 2014; Lancioni, Singh, O’Reilly, Sigafoos, Boccasini, } \\
\text { Martire ve Lang,2014; Lancioni, O’Reilly, Singh, Sigafoos, } \\
\text { Alberti, Boccasini, Oliva ve Lang, 2014; Lancioni, Singh, }\end{array}$ & 38 & 38.77 \\
\hline
\end{tabular}


O’Reilly, Sigafoos, Boccasini, Alberti ve Lang, 2014; Munde, Vlakamp, Maes ve Ruijssenaars, 2012; Nelson, Greenfield, Hyte ve Shaffer, 2013; Poppes, Putten ve Vlaskamp, 2014; Ricci, Miglino, Alberti, Perilli ve Lancioni, 2017; Stasolla, Caffo, Perilli, Boccasini, Stella, Damiani, Albano ve Damato, 2017; Shih, 2013; Shih, 2014; Wei, Blackorb ve Schiller, 2011.

Uygulama ile ilgili Axelsson, Granlund ve Wilder, 2013; Hostyn ve Maes, sinırlılıklar 2013; Boas, Ferreira, Moura, Maia ve Amaral, 2016; Dayı

2929.59
ve Şafak, 2018; Delden, Wintels, Oorsouw, Evers, Embregts, Heylen ve Reidsma, 2020; Desideri, Bizzarri, Bitelli, Roentgen, Gelderblom ve Witte, 2016; Eldeniz ve Bozak, 2020; Frederiks, Sterkenburg, Barakova, Feijs, 2019; Hanzen, Nispen, Vlaskamp, Korevaar, Waninge ve Putten, 2020; Holyfield, Light, Drager, McNaughton ve Gormley, 2018; Ivy, Hatton ve Wehby, 2018; Janssen, Brink-Groenendijk, Riksen-Walraven, Huisman, Dijk ve Ruijssenaars, 2014; Kemp, Stephenson, Cooper ve Hodge, 2016; Knapik-Szweda, 2019; Krämer ve Zentel, 2020; Lancioni, Singh, O’Reilly, Sigafoos, Alberti, Perilli, Zimbaro, Boccasini, Mazzola ve Russo, 2018; Lancioni, Singh, O’Reilly, Sigafoos, Alberti, Perilli, Boccasini, Martire ve Zagaria, 2017; Lancioni, Singh, O’Reilly, Sigafoos, Alberti ve Campodonico, 2016; Lancioni, O’Reilly, Singh, Sigafoos, Boccasini, Martire, Perilli, Spagnuolo, 2016; Nijs, Vlaskamp ve Maes, 2020; Poppes, Putten, Frans, Brug ve Vlaskamp, 2016; Shogren, Kennedy, Dowsett ve Little, 2014; Lancioni, O’Reilly, Singh, Sigafoos, Oliva, Campodonico ve Lang, 2012; Nelson, Greenfield, Hyte ve Shaffer, 2013; Ramani, Police ve Jacob, 2014; Moir, 2010; Sadler, 2019; Taylor ve Preece, 2010; Wessels, Bossink ve Putten, 2017.

\begin{tabular}{l}
\hline Herhangi bir \\
sinırlılık \\
belirtilmeyen \\
çalışmalar
\end{tabular}

çalışmalar
Benford, 2017; Blain-Moraes ve Chau, 2012; Bullen, Luger, Prudhomme ve Geiger, 2018; Cunha, Neiva ve Silva, 2019; Felicio, Seabra-Junior, Rodrigues, 2019; Holmqvist, Derbring ve Wallin, 2017; Neagu ve Zsuzsanna, 2020; Lancioni, Singh, O’Reilly, Green, Meer, Alberti, Perilli, Boccasini, Martire ve Lang, 2015; Lancioni, O’Reilly, Singh, Green, Oliva, Campodonico, Lang ve Buono, 2013; Jongbloed-Pereboom, Peeters, Overvelde, Sanden ve Steenbergen, 2015; Chang, Lee, Chou, Chen ve Chen, 2011; Lancioni, Singh, O'Reilly, Sigafoos, Oliva, Alberti ve Buono, 2014; Lancioni, Singh, O’Reilly, Sigafoos, Oliva, Shih, 2013; Kumar, 2013; Lancioni, O’Reilly, Singh, Sigafoos, Oliva, Alberti, Carrella, Didden ve Lang, 2013; Lancioni, Singh, O’Reilly, Green, Oliva, Buonocunto, Sacco, Biancardi ve Di Nuovo, 2012; Lancioni, O’Reilly, Singh, Green, Oliva, Buonocunto, Colonna ve Navarro, 2012; Lancioni, Bellini, Oliva, Singh, O’Reilly, Lang, Didden ve Bosco, 2011; Lancioni, Singh, O’Reilly, Sigafoos, Oliva, Signorino ve Tommaso, 2010, Lancioni, Singh, O'Reilly, Sigafoos, Belardinelli, Buonocunto, D’Amico, Navarro, Lanzilotti, Denitto, Tommaso ve Megna, 2015; Pilesjö ve Norén, 2017; Shih, Shih ve Wang, 2010.

Araç gereçle ilgili Shih, 2012; Mechling ve Bishop, 2011; Shih, 2011; Shih, sinirliliklar Cheng, Li, Shih ve Chiang, 2010. 


\begin{tabular}{llcc}
\hline $\begin{array}{l}\text { Uyaranlar ile ilgili } \\
\text { sinırlılıklar }\end{array}$ & Munde ve Vlaskamp, 2014; Trief, Cascella ve Bruce, & 3 & 3.06 \\
\hline $\begin{array}{l}\text { Ortamla ilgili } \\
\text { Sinırlılıklar }\end{array}$ & Lancioni, Singh, O'Reilly, Sigafoos, Boccasini, Martire, & 2 & 2.04 \\
\hline $\begin{array}{l}\text { Başlama düzeyi } \\
\text { verisi } \\
\text { toplanmamıștır }\end{array}$ & Ferreira, Travassos, Alves, Sampaio ve Pereira-Guizzo, & 1 & 1.02 \\
\hline
\end{tabular}

Ele alınan çalışmaların yaklaşık beşte birinde (\%21.47'sinde) herhangi bir sınırlılık belirtilmediği görülmektedir. Çalışmaların \%38.77'sinde katılımcılarla ilgili sınırlılık belirtilmektedir. Katılımcılarla ilgili sınırlılığın yarısından çoğu denek sayısının azlığıyla ilgilidir. Tek denekli çalışmalarda denek sayısının azlığı kabul edilebilir bir sınırlılıktır. Çalışmalarda diğer bir sınırlılık nedeni olarak uygulama ile ilgili sınırlılıklardan (\%29.59) bahsedilmektedir. Araştırmacılar uygulamadaki sınırlılıkları tek bir davranışa yönelik uygulama yapılması, analize dayalı çalışmaların sınırlı veri üzerinden toplanması, katılımcı tepkisinin dikkate alınmaması, uygulamayı yapan bakıcıların uygulamaya ilişkin yeterlilik düzeylerinin düşük olması, uygulama ortamının sabit olmaması ve iyi hazırlanmaması olarak sıralamışlardır. Belirtilen sınırlılıkların uygulama güvenirliğini etkileyecek düzeyde olduğu gözlenmektedir. Çalışmaların uygulama ortamlarında yapıldığı, yapılan eğitim ve sağaltımların bilimsel çalışma formatında yapılmaya çalışıldığını düşündürmektedir.

Sonuçlarına Göre Araştırma Bulguları: İncelenen 96 makalenin sonuçlarına göre sinıflanması Tablo 5'te özetlenmiștir.

Tablo 5

\section{Ele Alınan Çalışmaların Sonuçlarına Göre Dağılımları}

\begin{tabular}{lll}
\hline Sonuçlar & Yazar & $\mathrm{n}$ \\
\hline Teknoloji destekli & Benford, 2017; Bossink, Putten, Waninge ve Vlaskamp, & 65 \\
uygulamalar veya & 2017; Bullen, Luger, Prudhomme ve Geiger, 2018; & 69.14 \\
geliștirilen & Cunha, Neiva ve Silva, 2019; Dayı ve Şafak, 2018; \\
programlarla beceri & Delden, Wintels, Oorsouw, Evers, Embregts, Heylen ve \\
kazandırma ve & Reidsma, 2020; Desideri, Bizzarri, Bitelli, Roentgen, \\
davranış değișikliği & Gelderblom ve Witte, 2016; Eldeniz ve Bozak, 2020; \\
yaratmada etkili olan & Frederiks, Sterkenburg, Barakova, Feijs, 2019; \\
araștırmalar. & Holyfield, Light, Drager, McNaughton ve Gormley, \\
& 2018; Holyfield, 2019; Holyfield, Brooks ve \\
& Schluterman, 2019; Hudson, Zambone ve Brickhouse, \\
& 2016; Ivy, Hatton ve Wehby, 2018; Kemp, Stephenson, \\
& Cooper ve Hodge, 2016; Knapik-Szweda, 2019; \\
& Lancioni, Singh, O’Reilly, Sigafoos, Alberti, Chiariello ve \\
& Carrella, 2020; Lancioni, Singh, O’Reilly, Sigafoos, \\
Campodonico, Alberti, Perilli, Zimbaro, Chiariello ve \\
Campodonico, 2018; Lancioni, Singh, O’Reilly, Sigafoos, \\
Campodonico, Oliva, Alberti ve D’amico, 2018; \\
Lancioni, Singh, O’Reilly, Sigafoos, Campodonico, \\
Zimbaro, Alberti, Trubia ve Zagaria, 2018; Lancioni, \\
Singh, O’Reilly, Sigafoos, Alberti, Perilli, Zimbaro, \\
Boccasini, Mazzola ve Russo, 2018; Lancioni, Singh, \\
O’Reilly, Sigafoos, Alberti, Campodonico, Perilli, \\
\hline
\end{tabular}


Chiariello ve Zimbaro, 2017; Lancioni, Singh, O’Reilly, Sigafoos, Alberti, Zimbaro ve Chiariello, 2017; Lancioni, Singh, O'Reilly, Sigafoos, Alberti, Perilli ve Campodonic, 2017; Lancioni, Singh, O’Reilly, Sigafoos, D’Amico, Buonocunto, Navarro, Lanzilotti ve Alberti, 2017; Lancioni, O’Reilly, Sigafoos, Campodonico Perilli, Alberti, Ricci ve Miglino, 2017; Lancioni, Singh, O’Reilly, Sigafoos, Campodonico ve Alberti, 2017; Lancioni, Singh, O’Reilly, Sigafoos, Alberti, Perilli, Boccasini, Martire ve Zagaria, 2017; Lancioni, Singh, O’Reilly, Sigafoos, Alberti ve Campodonico, 2016; Lancioni, O’Reilly, Singh, Sigafoos, Boccasini, Martire, Perilli, Spagnuolo, 2016; Lancioni, Singh, O’Reilly, Sigafoos, Boccasini, Martire ve Smaldone, 2016; Lancioni, Singh, O’Reilly, Green, Meer, Alberti, Perilli, Boccasini, Martire ve Lang, 2015; Munde ve Vlaskamp, 2014; Lancioni, O’Reilly, Singh, Green, Oliva, Campodonico, Lang ve Buono, 2013; Lancioni, Singh, O’Reilly, Sigafoos, Belardinelli, Buonocunto, D’Amico, Navarro, Lanzilotti, Denitto, Tommaso ve Megna, 2015; Shih, 2014; Lancioni, Singh, O’Reilly, Sigafoos, Oliva, Alberti ve Buono, 2014; Lancioni, Singh, O'Reilly, Sigafoos, Boccasini, Alberti ve Lang, 2014; Lancioni, Singh, O’Reilly, Sigafoos, Oliva, Campodonico, Alberti ve Lang, 2014; Lancioni, Singh, O'Reilly, Sigafoos, Boccasini, Martire, Oliva ve Lang, 2014; Lancioni, Singh, O’Reilly, Sigafoos, Boccasini, Martire ve Lang, 2014; Lancioni, O’Reilly, Singh, Sigafoos, Alberti, Boccasini, Oliva ve Lang, 2014; Argyropoulos ve Thymakis, 2014; Shih, 2013; Lancioni, Singh, O'Reilly, Green, Oliva ve Campodonico, 2013; Lancioni, O’Reilly, Singh, Sigafoos, Oliva, Alberti, Carrella, Didden ve Lang, 2013; Neagu ve Zsuzsanna, 2020; Pilesjö ve Norén, 2017; Ferreira, Travassos, Alves, Sampaio ve Pereira-Guizzo, 2013; Nelson, Greenfield, Hyte ve Shaffer, 2013; Shih, 2012; Munde, Vlakamp, Maes ve Ruijssenaars, 2012; Lancioni, O’Reilly, Singh, Sigafoos, Oliva, Campodonico ve Lang, 2012; Lancioni, O’Reilly, Singh, Green, Oliva, Buonocunto, Colonna ve Navarro, 2012; Blain-Moraes ve Chau, 2012; Lancioni, Singh, O'Reilly, Green, Oliva, Buonocunto, Sacco, Biancardi ve Di Nuovo, 2012; Lancioni, Bellini, Oliva, Singh, O'Reilly, Lang, Didden ve Bosco, 2011; Chang, Lee, Chou, Chen ve Chen, 2011; Mechling ve Bishop, 2011; Shih, 2011; Shih, Cheng, Li, Shih ve Chiang, 2010; Lancioni, Singh, O’Reilly, Sigafoos, Oliva, Signorino ve Tommaso, 2010; Shih, Shih ve Wang, 2010; Ricci, Miglino, Alberti, Perilli ve Lancioni, 2017; Stasolla, Caffo, Perilli, Boccasini, Stella, Damiani, Albano ve Damato, 2017.

Etkileșim ve iletişim kazandırma ve yönlendirmede etkili olan çalışmalar
Boas, Ferreira, Moura, Maia ve Amaral, 2016; Brug, Putten, Penne, Maes ve Vlaskamp, 2016; Felicio, Seabra-Junior, Rodrigues, 2019; Hanzen, Nispen, Vlaskamp, Korevaar, Waninge ve Putten, 2020; Lancioni, Singh, O’Reilly, Sigafoos, Resta, Campodonico Alberti ve Chiariello, 2020; Lancioni, Singh, O'Reilly, Sigafoos, Boccasini, Perilli ve Spagnuolo, 2017; Nijs, Vlaskamp ve Maes, 2020;

Hostyn ve Maes, 2013; Kumar, 2013; Johnson ve Parker, 2013; Taylor ve Preece, 2010. 


\begin{tabular}{|c|c|c|c|}
\hline $\begin{array}{l}\text { Değerlendirme } \\
\text { aracı/uygulama } \\
\text { geliștirme } \\
\text { araştırmaları }\end{array}$ & $\begin{array}{l}\text { Depountis, Okungu ve Molloy-Daugherty, 2019; } \\
\text { Ferreira, Zotz, Melo ve Israel 2019; Holmqvist, } \\
\text { Derbring ve Wallin, 2017; Janssen, Brink-Groenendijk, } \\
\text { Riksen-Walraven, Huisman, Dijk ve Ruijssenaars, 2014; } \\
\text { Krämer ve Zentel, 2020; Shogren, Kennedy, Dowsett ve } \\
\text { Little, 2014; Wei, Blackorby ve Schiller, 2011. }\end{array}$ & 7 & 7.44 \\
\hline $\begin{array}{l}\text { Problem } \\
\text { davranışlarının } \\
\text { azaltılmasında etkili } \\
\text { olan çalıșmalar }\end{array}$ & $\begin{array}{l}\text { Bosch, Andringa, Peterson, Ruijssenaars ve Vlaskamp, } \\
\text { 2017; Desrochers, Oshlag ve Kennelly, 2014; Poppes, } \\
\text { Putten ve Vlaskamp, 2014; Poppes, Putten, Frans, Brug } \\
\text { ve Vlaskamp, 2016; Sadler, } 2019 .\end{array}$ & 5 & 5.31 \\
\hline $\begin{array}{l}\text { Akademik beceri } \\
\text { kazandırmada etkili } \\
\text { olan çalışmalar }\end{array}$ & $\begin{array}{l}\text { Holyfield, Caron, Light ve McNaughton, 2019; } \\
\text { Jongbloed-Pereboom, Peeters, Overvelde, Sanden ve } \\
\text { Steenbergen, 2015; Poppes, Putten ve Vlaskamp, 2014; } \\
\text { Ramani, Police ve Jacob, 2014. }\end{array}$ & 4 & 4.25 \\
\hline $\begin{array}{l}\text { Sembol pekiştirme } \\
\text { uygulamasının } \\
\text { etkililiğine ilişkin } \\
\text { yetersizlik rapor eden } \\
\text { çalıșma }\end{array}$ & Trief, Cascella ve Bruce, 2013 & 1 & 1.06 \\
\hline $\begin{array}{l}\text { Beklenen etkinin } \\
\text { bulunamadığı } \\
\text { araștırmalar }\end{array}$ & Wessels, Bossink ve Putten, 2017. & 1 & 1.06 \\
\hline
\end{tabular}

Ele alınan çalışmaların \%69'unda kullanılmış olan teknoloji destekli uygulamaların çoklu yetersizliğe sahip bireylere farklı becerileri kazandırmada etkili olduğu belirlenmiştir. Çalışmalar incelendiğinde teknoloji destekli uygulamaların; araştırma ekibi tarafından özel hazırlanmış yada düzenlenmiş programlar, algılayıcı sensörler, mikro anahtarlar, özel yazılımlar, bilgisayar, telefon ve video gibi araç gereçlerden oluştuğu görülmektedir. Teknoloji destekli bu uygulamalar ile telefondan mesaj yazma, bakıcısına seslenme gibi pek çok farklı becerinin çalışıldığı görülmektedir. Çalışmaların bir kısmında teknolojik uyarlamaların var olan teknolojik donanımların yapılarının uyarlanarak yeniden imal edildiği gözlenmektedir. Ancak diğer teknolojik desteklerin ileri teknoloji kullanımı düzeyinde olmadığı, dolayısıyla kolaylıkla yapılabilir ve uygulanabilir olduğu belirlenmiştir. Örneğin; mikro anahtarlarlar ve minimal hareket algılayıcıları günümüzde pek çok yerde kullanılan teknolojik araçlardır. Bunun çoklu ve ileri düzeyde yetersizliğe sahip bireylerin bakıcılarıyla iletişimlerini ve istek ifadelerini belirtme amacıyla (\%11.7) bireyin yatağında düzenek oluşturmak için kullanılması oldukça işlevseldir.

Çoklu ve ileri düzeyde yetersizliğe sahip bireylerin değerlendirilmesi amacıyla yapılan çalışmalar (\%7.44) onların eğitim gereksinimlerinin belirlenmesi ve eğitsel gereksinimlerini giderecek düzenleme ve programlamanın oluşturulması açısından oldukça önemlidir. Günümüzde çoklu ve ileri düzeyde yetersizliğe sahip bireylerin tanımlanması, değerlendirilmesi, eğitim ortamlarının ve programlarının oluşturulmasındaki belirsizliğin olumsuz etkileri bilinmektedir (Turnbull, Turnbull, Shank, Smith ve Leal, 2002).

Çalışmalar arasında uygulamanın etkisiz olduğu çalışmaları incelediğimizde bir çalışmanın uygulama süreciyle ilgili sorunları olduğu belirlenmiştir (Trief, Cascella ve Bruce, 2013). Shogren, Kennedy, DowSett ve Little (2014) tarafından yapılan diğer bir çalışma ölçü aracının uyarlanmasıyla ilgili bir çalışmadır. Bu çalışmada Wehmeyer ve 
Kelchner (1995) kendini yönetme ölçeğinin dört alt ölçeğinin olduğu gibi alınmasının sorun yarattığını ifade etmiştir.

Önerilerine Göre Araştırma Bulguları: İncelenen 96 makalenin önerilere göre sınıflanması Tablo 6'da özetlenmiştir.

\section{Tablo 6}

Ele Alınan Çalışmaların Önerilerine göre Göre Dağılımları

\begin{tabular}{|c|c|c|c|}
\hline Öneriler & Yazar & $\mathrm{n}$ & $\%$ \\
\hline $\begin{array}{l}\text { Uygulamanın sistematize } \\
\text { edilerek, geliștirilerek } \\
\text { yinelenmesini öneren } \\
\text { araştırmalar. }\end{array}$ & $\begin{array}{l}\text { Benford, 2017; Bossink, Putten, Waninge ve Vlaskamp, } \\
\text { 2017; Dayı ve Şafak, 2018; Delden, Wintels, Oorsouw, } \\
\text { Evers, Embregts, Heylen ve Reidsma, 2020; Eldeniz ve } \\
\text { Bozak, 2020; Frederiks, Sterkenburg, Barakova, Feijs, } \\
\text { 2019; Holmqvist, Derbring ve Wallin, 2017; Holyfield, } \\
\text { Light, Drager, McNaughton ve Gormley, 2018; Holyfield, } \\
\text { 2019; Holyfield, Brooks ve Schluterman, 2019; } \\
\text { Holyfield, Caron, Light ve McNaughton, 2019; Hudson, } \\
\text { Zambone ve Brickhouse, 2016; Ivy, Hatton ve Wehby, } \\
\text { 2018; Jongbloed-Pereboom, Peeters, Overvelde, } \\
\text { Sanden ve Steenbergen, 2015; Knapik-Szweda, 2019; } \\
\text { Krämer ve Zentel, 2020; Lancioni, Singh, O’Reilly, } \\
\text { Sigafoos, Alberti, Chiariello ve Carrella, 2020; Lancioni, } \\
\text { Singh, O’Reilly, Sigafoos, Resta, Campodonico Alberti ve } \\
\text { Chiariello, 2020; Lancioni, Singh, O’Reilly, Sigafoos, } \\
\text { Campodonico, Oliva, Alberti ve D’amico, 2018; Lancioni, } \\
\text { Singh, O’Reilly, Sigafoos, Alberti, Perilli, Zimbaro, } \\
\text { Boccasini, Mazzola ve Russo, 2018; Lancioni, Singh, } \\
\text { O’Reilly, Sigafoos, Boccasini, Perilli ve Spagnuolo, 2017; } \\
\text { Lancioni, Singh, O’Reilly, Sigafoos, Alberti, Zimbaro ve } \\
\text { Chiariello, 2017; Lancioni, O’Reilly, Sigafoos, } \\
\text { Campodonico Perilli, Alberti, Ricci ve Miglino, 2017; } \\
\text { Lancioni, Singh, O’Reilly, Sigafoos, Alberti, Perilli ve } \\
\text { Campodonic, 2017; Lancioni, Singh, O’Reilly, Sigafoos, } \\
\text { Alberti, Perilli, Boccasini, Martire ve Zagaria, 2017; } \\
\text { Lancioni, Singh, O’Reilly, Sigafoos, Boccasini, Martire ve } \\
\text { Smaldone, 2016; Neagu ve Zsuzsanna, 2020; Nijs, } \\
\text { Vlaskamp ve Maes, 2020; Poppes, Putten ve Vlaskamp, } \\
\text { 2014; Desrochers, Oshlag ve Kennelly, 2014; Shogren, } \\
\text { Kennedy, Dowsett ve Little, 2014; Hostyn ve Maes, } \\
\text { 2013; Janssen, Brink-Groenendijk, Riksen-Walraven, } \\
\text { Huisman, Dijk ve Ruijssenaars, 2014; Johnson ve } \\
\text { Parker, 2013; Ferreira, Travassos, Alves, Sampaio ve } \\
\text { Pereira-Guizzo, 2013; Chang, Lee, Chou, Chen ve Chen, } \\
\text { 2011; Lancioni, Singh, O’Reilly, Sigafoos, Oliva, } \\
\text { Signorino ve Tommaso, 2010; Pilesjö ve Norén, 2017; } \\
\text { Wessels, Bossink ve Putten, 2017. }\end{array}$ & 39 & 33.05 \\
\hline $\begin{array}{l}\text { Farklı yetersizliğe sahip } \\
\text { bireylerle yinelenmesi ve } \\
\text { genelleme çalışması } \\
\text { öneren araştırmalar }\end{array}$ & $\begin{array}{l}\text { Boas, Ferreira, Moura, Maia ve Amaral, 2016; Brug, } \\
\text { Putten, Penne, Maes ve Vlaskamp, 2016; Cunha, Neiva } \\
\text { ve Silva, 2019; Desideri, Bizzarri, Bitelli, Roentgen, } \\
\text { Gelderblom ve Witte, 2016; Felicio, Seabra-Junior, } \\
\text { Rodrigues, 2019; Ferreira, Zotz, Melo ve Israel 2019; } \\
\text { Hanzen, Nispen, Vlaskamp, Korevaar, Waninge ve } \\
\text { Putten, 2020; Jongbloed-Pereboom, Peeters, Overvelde, } \\
\text { Sanden ve Steenbergen, 2015; Kemp, Stephenson, } \\
\text { Cooper ve Hodge, 2016; Lancioni, Singh, O’Reilly, }\end{array}$ & 31 & 26.27 \\
\hline
\end{tabular}


Sigafoos, Campodonico, Alberti, Perilli, Zimbaro, Chiariello ve Campodonico, 2018; Lancioni, Singh, O’Reilly, Sigafoos, Campodonico, Zimbaro, Alberti, Trubia ve Zagaria, 2018;Lancioni, Singh, O'Reilly, Sigafoos, Alberti, Campodonico, Perilli, Chiariello ve Zimbaro, 2017; Lancioni, Singh, O’Reilly, Sigafoos, Campodonico ve Alberti, 2017; Lancioni, Singh, O’Reilly, Sigafoos, Belardinelli, Buonocunto, D’Amico, Navarro, Lanzilotti, Denitto, Tommaso ve Megna, 2015; Lancioni, Singh, O’Reilly, Green, Meer, Alberti, Perilli, Boccasini, Martire ve Lang, 2015; Shih, 2014; Lancioni, Singh, O'Reilly, Sigafoos, Oliva, Campodonico, Alberti ve Lang, 2014; Lancioni, Singh, O’Reilly, Sigafoos, Boccasini, Alberti ve Lang, 2014; Lancioni, O’Reilly, Singh, Sigafoos, Alberti, Boccasini, Oliva ve Lang, 2014; Lancioni, O'Reilly, Singh, Sigafoos, Oliva, Alberti, Carrella, Didden ve Lang, 2013; Ramani, Police ve Jacob, 2014; Lancioni, O'Reilly, Singh, Sigafoos, Oliva, Campodonico ve Lang, 2012; Johnson ve Parker, 2013; Lancioni, Singh, O’Reilly, Green, Oliva, Buonocunto, Sacco, Biancardi ve Di Nuovo, 2012; Lancioni, O'Reilly, Singh, Green, Oliva, Buonocunto, Colonna ve Navarro, 2012; Shih, 2011; Taylor ve Preece, 2010; Lancioni, Bellini, Oliva, Singh, O'Reilly, Lang, Didden ve Bosco, 2011; Ricci, Miglino, Alberti, Perilli ve Lancioni, 2017; Sadler, 2019; Stasolla, Caffo, Perilli, Boccasini, Stella, Damiani, Albano ve Damato, 2017

Kullanılan aracın uyarlanarak, geliştirerek çalışmanın yinelenmesini öneren araștırmalar.
Bosch, Andringa, Peterson, Ruijssenaars ve Vlaskamp, 2017; Bullen, Luger, Prudhomme ve Geiger, 2018; Depountis, Okungu ve Molloy-Daugherty, 2019; Lancioni, Singh, O'Reilly, Sigafoos, Alberti ve Campodonico, 2016; Lancioni, O'Reilly, Singh, Sigafoos, Boccasini, Martire, Perilli, Spagnuolo, 2016; Lancioni, Singh, O’Reilly, Sigafoos, D'Amico, Buonocunto, Navarro, Lanzilotti ve Alberti, 2017; Lancioni, Singh, O'Reilly, Sigafoos, Boccasini, Martire, Oliva ve Lang, 2014; Lancioni, Singh, O’Reilly, Sigafoos, Boccasini, Alberti ve Lang, 2014; Shih, 2014; Lancioni, Singh, O'Reilly, Sigafoos, Oliva, Alberti ve Buono, 2014; Lancioni, O’Reilly, Singh, Sigafoos, Oliva, Alberti, Carrella, Didden ve Lang, 2013; Shih, 2013; Shih, 2012; Lancioni, Singh, O’Reilly, Green, Oliva, Buonocunto, Sacco, Biancardi ve Di Nuovo, 2012; Mechling ve Bishop, 2011; Shih, Shih ve Wang, 2010; Poppes, Putten, Frans, Brug ve Vlaskamp, 2016; Shih, Cheng, Li, Shih ve Chiang, 2010.

Sosyal geçerlilik verisinin de toplanmasını öneren araştırmalar. Lancioni, O'Reilly, Singh, Green, Oliva, Campodonico, Lang ve Buono, 2013; Lancioni, Singh, O'Reilly, Sigafoos, Belardinelli, Buonocunto, D’Amico, Navarro, Lanzilotti, Denitto, Tommaso ve Megna, 2015; Lancioni, Singh, O'Reilly, Green, Meer, Alberti, Perilli, Boccasini, Martire ve Lang, 2015; Lancioni, Singh, O’Reilly, Sigafoos, Boccasini, Alberti ve Lang, 2014; Lancioni, Singh, O'Reilly, Sigafoos, Oliva, Campodonico, Alberti ve Lang, 2014; Lancioni, O’Reilly, Singh, Sigafoos, Alberti, Boccasini, Oliva ve Lang, 2014; Lancioni, Singh, O’Reilly, Sigafoos, Boccasini, Martire ve Lang, 2014; Lancioni, O’Reilly, Singh, Sigafoos, Oliva, Alberti, Carrella, Didden ve Lang, 2013; Lancioni, O’Reilly, Singh, Green, Oliva, 
Buonocunto, Colonna ve Navarro, 2012; Lancioni, O’Reilly, Singh, Sigafoos, Oliva, Campodonico ve Lang, 2012; Lancioni, Singh, O’Reilly, Green, Oliva, Buonocunto, Sacco, Biancardi ve Di Nuovo, 2012; Mechling ve Bishop, 2011.

Uygulamacı yeterliliğinin arttırılarak uygulamanın yinelenmesini öneren araştırmalar.

Farklı beceriler için uygulamanın yinelenmesini öneren araştırmalar.
Munde ve Vlaskamp, 2014; Argyropoulos ve Thymakis, 2014; Nelson, Greenfield, Hyte ve Shaffer, 2013; Trief, Cascella ve Bruce, 2013; Hostyn ve Maes, 2013.

\section{Lancioni, Singh, O’Reilly, Sigafoos, Boccasini, Martire ve} Lang, 2014; Lancioni, O’Reilly, Singh, Green, Oliva, Buonocunto, Colonna ve Navarro, 2012; Munde, Vlakamp, Maes ve Ruijssenaars, 2012. Maliyeti düşürülerek
çalıșmanın yinelenmesini
öneren araştırmalar.
Lancioni, Singh, O’Reilly, Green, Meer, Alberti, Perilli, Boccasini, Martire ve Lang, 2015; Lancioni, Singh, O’Reilly, Green, Oliva ve Campodonico, 2013.

\begin{tabular}{|c|c|c|c|}
\hline $\begin{array}{l}\text { Katılımcı/deneğin } \\
\text { görüşünün alınmasını } \\
\text { öneren araştırmalar. }\end{array}$ & $\begin{array}{l}\text { Poppes, Putten ve Vlaskamp, 2014; Lancioni, O’Reilly, } \\
\text { Singh, Sigafoos, Oliva, Campodonico ve Lang, } 2012 .\end{array}$ & 2 & 1.69 \\
\hline $\begin{array}{l}\text { Öğretilen becerinin eve } \\
\text { genellemesini öneren } \\
\text { araştırmalar. }\end{array}$ & $\begin{array}{l}\text { Axelsson, Granlund ve Wilder, 2013; Lancioni, Singh, } \\
\text { O’Reilly, Sigafoos, Oliva, Signorino ve Tommaso, } 2010 .\end{array}$ & 2 & 1.69 \\
\hline
\end{tabular}

\begin{tabular}{|c|c|c|c|}
\hline $\begin{array}{l}\text { Norm geliștirme çalıșması } \\
\text { öneren araștırmalar. }\end{array}$ & Wei, Blackorby ve Schiller, 2011. & 1 & 0.84 \\
\hline $\begin{array}{l}\text { Aynı becerinin farklı } \\
\text { teknolojik araçla } \\
\text { öğretimini öneren } \\
\text { araștırmalar. }\end{array}$ & Blain-Moraes ve Chau, 2012 & 1 & 0.84 \\
\hline $\begin{array}{l}\text { Kazandırılan becerinin } \\
\text { önkoşul beceri olarak } \\
\text { kullanılmasını öneren } \\
\text { araștırmalar. }\end{array}$ & Moir, 2010 & 1 & 0.84 \\
\hline $\begin{array}{l}\text { Erken müdahale öneren } \\
\text { araştırmalar. }\end{array}$ & Kumar, 2013 & 1 & 0.84 \\
\hline
\end{tabular}

Çalışmaların \%26.27'sinde araştırmacılar yapılan çalışmanın farklı yetersizliğe sahip bireylerle yinelenmesini önermişlerdir. İncelenen araştırmaların yarısından fazlasının (\%66.66) tek denekli araştırma modeli kullanılarak yapıldığı düşünüldüğünde, bu modeldeki araştırmaların bulgularının genellenebilirliği için bu önerinin yapılması olağandır. Yarı deneysel çalışma olan tek denekli araştırma modellerinde genellenebilirlik tekrarlı çalışmalarla sağlanabilmektedir.

Çalışmaların \%33.05'inde "uygulamanın sistematize edilerek, geliştirilerek yinelenmesi", \%4.23'ünde de "uygulamacı yeterliliğinin arttırılarak uygulamanın yinelenmesi" önerilmektedir. Sınırlılıklarla ilgili bulgulara bakıldığında uygulama ile ilgili sınırlılığının olduğu görülmektedir. Bu sebeple öneriler içerisinde çalışmaların bir kısmında "aynı çalışmanın deneysel olarak çalıșılması” önerilmektedir. 
Çalışmaların \%10.16’sında farklı nedenlerle sosyal geçerlik verilerinin toplanamadığı belirtilerek sonraki çalışmalara öneri olarak ifade edilmiştir. Çalışmalar sonunda çoklu ve ileri düzeyde yetersizliğe sahip bireylerin kazanımlarının ebeveynler, bakıcılar ve onlarla etkileşen diğer uzman ve kişileri olumlu etkilediği, ancak verisi toplanmadığı için bunun bir kayıp olduğunu belirtilmiştir. Bu çalışmaların bir kısmında "katılımcının/deneğin görüşünün alınmasını" öneren çalışmalar da vardır.

Çalışmalarda teknoloji destekli uygulamaların yapıldığı araştırmalardan \%12'sinde uygulama sırasında bir miktar daha uyarlama yapılması halinde uygulamanın daha kolay gerçekleşebileceği fark edilmiş, araştırma sistematiği nedeniyle uygulama sürdürülmüş ancak öneri olarak sonraki araștırmacılara bu bilgi iletilmiştir.

\section{SONUÇ, TARTIŞMA VE ÖNERİLER}

Araştırma bulgularından elde edilen sonuçlar çoklu yetersizliği olan bireylere etkileşim becerileri, iletişim becerileri, motor beceriler, günlük yaşam becerileri, boş zaman ve oyun becerileri, akademik ve iş becerileri gibi pek çok becerinin öğretilebildiğini göstermektedir. Bulgular ister çocuk isterse yetişkin olsun çoklu yetersizliği olan bireylere kazandırılması hedeflenen bütün davranış ve becerileri edinebildiklerini göstermektedir. Bu bulgular tek yetersizlik alanında yapılan çalışmaların benzerinin bilimsel dayanaklı uygulamaların çoklu yetersizliğe sahip bireyler için de yapılabileceğini düşündürmektedir.

Araştırmada, 96 makaleden elde edilen sonuçlar incelendiğinde elde edilen bulgular çoklu yetersizliği olan bireylere teknoloji destekli uygulamaların beceri kazandırma ve davranış değişikliği yaratmada etkili olduğunu göstermiştir (Argyropoulos ve Thymakis, 2014; Lancioni ve diğerleri 2012; Lancioni ve diğerleri 2006; Lancioni ve diğerleri 2010; Moir, 2010; Shih, 2014; Shih, 2013; Shih, 2011; Shih ve diğerleri 2010; Shih ve diğerleri 2010). Çalışmalarda kullanılan teknolojik araçların günümüzde ülkemizde de kullanıldığı ve dolayısıyla etkiliği belirlenmiş benzer çalışmaların yapılabileceği düşünülmüştür. Bulgular, çoklu yetersizliği olan bireylere etkileşim ve iletişim becerilerinin teknoloji destekli uygulamalarla kazandırılabildiğini ve onların çevresiyle etkileşime girmesinin sağlanabildiğini göstermektedir. Temel etkileşim becerilerinin hedeflendiği çalışmalarla çoklu yetersizliği olan bireylerin yaşam kalitesi arttırılmış, tercihlerini ifade etmeleri sağlanmıştır. (Johnson ve Parker, 2013; Kumar, 2013; Lancioni ve diğerleri 2015; Lancioni ve diğerleri 2014; Lancioni ve 2014; Lancioni ve diğerleri 2011). Sosyal bir varlık olarak çevresiyle etkileşim kurabilmek tüm bireyler için olduğu gibi çoklu yetersizliğe sahip bireyler için de vazgeçilmezdir. Araştırma bulguları çoklu yetersizliği olan bireylerin problem davranışlarının yapılan uygulamalarla azaltılabildiğini göstermiştir (Desrochers ve diğerleri, 2014; Lancioni ve diğerleri, 2013; Poppes ve diğerleri 2014). Bu bulgu bireyin kendisine zarar veren problem davranışların, sahip olduğu çoklu yetersizliğe bağlanmaması ve sistematik çalışmalarla giderilmesine ilişkin girişimlerin başlatılması gerektiğini göstermektedir. 
Sınırlı sayıda da olsa araştırma bulguları, çoklu yetersizliği olan bireylere akademik becerilerin kazandırılabildiğini göstermektedir (Jongbloed ve diğerleri, 2015; Ramani, Police ve Jacob, 2014; Wei, Blackorby ve Schiller, 2011). Bu çalışmalar okuma yazma becerilerinin öğretiminde başarılı olunabileceğini ve vazgeçilmemesi gerektiğini göstermektedir. Bu çalışmaların tamamında teknoloji destekli olarak okuma yazma becerisi çalışılmış, elle yazma ve sesletim yapabilme okuma yazma için önkoşul olarak değerlendirilmemiştir. Sadece dokunmatik ekrana dokunabilmesi yazma öğretimi için yeterli motor beceri olarak düşünülmüştür. Çoklu yetersizliğe sahip bireyler için akademik bir beceri olan okumanın, verimli bir boş zaman etkinliği olarak çalışma konuları içinde yer almasının sağlaması gerekmektedir.

Alanyazında yapılan çalışmalar çoklu ve ileri düzeyde yetersizliğe sahip bireylere ilişkin çalışmaların artarak sürdürülmesi gerektiğini düşündürmektedir. Ağır ve çoklu yetersizliğin normal nüfus içindeki bireylerin \% 1'i kadar olduğu bilinmektedir. Ayrıca bu oranın yaklaşık \% 40'ında ek yetersizlikler vardır (Hardin, 2006; Tam, Phillips ve Mudford, 2011). Çoklu yetersizliğe sahip bireyler motor becerilerde, bilişsel becerilerde, sosyal becerilerde ve öz bakım becerilerinde yaşadıkları güçlükler sebebiyle bağımsız yaşam sürdürmede ciddi güçlükler yaşamakta ve yaşamları boyunca desteğe gereksinim duymaktadırlar (Orelove ve Sobsey, 1996). Bu nedenle çoklu ve ileri düzeyde yetersizliğe sahip bireylerin bakımından sorumlu yakın çevresi de düşünüldügünde genel nüfusun yaklaşık \%5'ini etkileyen bir durumdan bahsedilmekte ve dolayısıyla yapılacak çalışmalar çok geniş bir kitleyi ilgilendirmektedir. Özellikle ülkemizde çoklu ve ileri düzeyde yetersizliğe sahip bireylere ilişkin yapılacak çalışmaların başlayarak, giderek arttırılması gereğinin de altını çizmek yararlı olacaktır.

Bu çalışmada çoklu ve ileri düzeyde yetersizliğe sahip bireylere yönelik araştırma yapmak isteyen çalışmacıların teknoloji destekli çalışmalara yönelmeleri ile ilgili bulgular sunulmuştur. Kullanılan teknoloji karmaşık teknik alt yapı gerektirmemektedir. Ancak yine de alan uzmanlarının tereddütleri olduğunda teknik bilgisi olan alandışı uzmanlarla da işbirliği yaparak çalışmalarını başlatabileceklerini belirtmekte yarar görülmektedir.

Çoklu ve ileri düzeyde yetersizliğe sahip bireylerle çalışan uygulamacıların, yapmayı planladıkları çalışmalarda başarısız olma kaygısına düşmeden, bu çalışmada örnekleri ve sonuçları paylaşılan bilimsel dayanaklı uygulamalarla çalışmalara başlama konusunda tereddüt etmemeleri önerilmektedir.

\section{Kaynaklar}

ABD Eğitim Bakanlığı. "Building the legacy: IDEA 2004” http://idea.ed.gov/explore/home adresinden erişildi. Akçamete, G. (1992). Çok engelli çocuklar. Ankara Üniversitesi Eğitim Fakültesi Dergisi, 24(1), 145-150.

Argyropoulos. V. ve Thymakis, P. (2014). Multiple disabilities and visual impairment: an action research project. Journal of Visual Impairment ve Blindness, 108(2), 163-167.

Axelsson, A. K., Granlund, M. ve Wilder, J. (2014) Engagement in family activities: a quantitative, comparative study of children with profound intellectual and multiple disabilities and children with typical development. Child Care Health and Development, 40(4), 457-457. 
Bahçeci, B. (2009). Çok engelli çocuklara iletişim becerilerinin kazandırılmasında yoğunlaştırılmış karşılıklı etkileşim yönteminin etkililiğinin değerlendirilmesi (Yüksek Lisans Tezi). Selçuk Üniversitesi Sosyal Bilimler Enstitüsü, Konya.

Bahçıvancıoğlu-Yazıcı, A. ve Akçin, N. (2014). Çoklu yetersizliği olan çocukların annelerinin çocuklarının gelişimlerine ilișkin görüșlerinin betimlenmesi. Ahi Evran Üniversitesi Kırșehir Eğitim Fakültesi Dergisi, 15(2).

Benford, F. (2017). Use of powered mobility for a young adult with profound and multiple learning disabilities: a practice analysis. British journal of occupational therapy, 80(8), 517-520.

Blain-Moraes, S. ve Chau, T. (2012). Challenges of developing communicative interaction in individuals with congenital profound intellectual and multiple disabilities. Journal of Intellectual ve Developmental Disability, 37(4), 348-359.

Boas, D. C., Ferreira, L. P., de Moura, M. C., Maia, S. R. ve Amaral, I. (2016). Analysis of interaction andnattention processes in a child with congenital deafblindness. American Annals of the Deaf, 161(3), 327-341.

Bosch, K. A., Andringa, T. C., Peterson, W., Ruijssenaars, W. A. ve Vlaskamp, C. (2017). A comparison of natural and non-natural soundscapes on people with severe or profound intellectual and multiple disabilities. Journal of Intellectual \& Developmental Disability, 42(3), 301-307.

Bossink, L. W., van der Putten, A. A., Waninge, A. ve Vlaskamp, C. (2017). A power-assisted exercise intervention in people with profound intellectual and multiple disabilities living in a residential facility: a pilot randomised controlled trial. Clinical Rehabilitation, 31(9), 1168-1178.

Brug, A., Van der Putten, A. A. J., Penne, A., Maes, B. ve Vlaskamp, C. (2016). Making a difference? A comparison between multi-sensory and regular storytelling for persons with profound intellectual and multiple disabilities. Journal of Intellectual Disability Research, 60(11), 1043-1053.

Bullen, A., Luger, R., Prudhomme, D. ve Geiger, M. (2018). Simple ideas that work: Celebrating development in persons with profound intellectual and multiple disabilities. African Journal of Disability (Online), 7, 110.

Chang, Y. J., Lee, M. Y., Chou, L. D., Chen, S. F. ve Chen, Y. C. (2011). A mobile wetness detection system enabling teachers to toilet train children with intellectual disabilities in a public school setting. Journal of Developmental and Physical Disabilities, 23(6), 527-533.

Cunha, R. D., Neiva, F. W. ve da Silva, R. L. D. S. (2019). Virtual reality-based training for the motor development of people with intellectual and multiple disabilities. Revista de Informática Teórica e Aplicada, 26(3), 40-49.

Çalık, M. ve Sözbilir, M. (2014). İçerik analizinin parametreleri. Ë̆itim ve Bilim, 39, 33-38.

Dayı, E.ve Şafak, P. (2018). Toilet training to a child with multiple disabilities using a toilet training package including" token economy" system: a case study. Egitim ve Bilim, 43(196), 301-316.

Delden, R. W., Wintels, S. C., van Oorsouw, W. M. W. J., Evers, V., Embregts, P. J. C. M., Heylen, D. K. J. ve Reidsma, D. (2020). Alertness, movement, and affective behavior of people with profound intellectual and multiple disabilities (PIMD) on introduction of a playful interactive product: Can we get your attention?. Journal of Intellectual \& Developmental Disability, 45(1), 66-77.

Depountis, V., Okungu, P. ve Molloy-Daugherty, D. (2019). The development of an application that supports body awareness for children with visual impairments and additional disabilities. Vision Rehabilitation International, 10(1), 1-8.

Desideri, L., Bizzarri, M., Bitelli, C., Roentgen, U., Gelderblom, G. J. ve de Witte, L. (2016). Implementing a routine outcome assessment procedure to evaluate the quality of assistive technology service delivery for children with physical or multiple disabilities: Perceived effectiveness, social cost, and user satisfaction. Assistive Technology, 28(1), 30-40.

Desrochers, M. N., Oshlag, R. ve Kennelly, A. M. (2014). Using background music to reduce problem behavior during assessment with an adolescent who is blind with multiple disabilities. Journal of Visual Impairment ve Blindness, 108(1), 31-66. 
Dünya Sağlık Örgütü, (1997). Let's Communicate”, $\quad$ Section 7 , http://whqlibdoc.who.int/hq/1997/WHO_RHB_97.1_7.pdf adresinden erişildi.

Düzkantar, A. (2014). Efficacy of teaching with simultaneous prompting in teaching the environmental sounds to a child with multiple disabilities. Hacettepe Üniversitesi Eğitim Fakültesi Dergisi, 29(1), 87-98.

Eldeniz Cetin, M. ve Bozak, B. (2020). The effectiveness of a training package prepared to teach first aid skills to individuals with intellectual and additional disabilities. International Education Studies, 13(3), 2742.

Felício, F. A. D. S., Seabra Junior, M. O. ve Rodrigues, V. (2019). Educational Toys Associated with Storytelling Used with a Child with Multiple Disabilities. Revista Brasileira de Educação Especial, 25(1), 67-84.

Ferreira, M. I. J., Travassos, X. L., Alves, L., Sampaio, R. ve Pereira-Guizzo, C. S. (2013). Digital games and assistive technology: Improvement of communication of children with cerebral palsy. International Journal of Special Education, 28(1), 36-46.

Ferreira, M. D. P., Zotz, T. G., Melo, T. R. ve Israel, V. L. (2019). Reports of case series of institutionalized adults with multiple disabilities: how to assess functionality?. Revista Brasileira de Educação Especial, 25(1), 55-66.

Frederiks, K., Sterkenburg, P., Barakova, E. ve Feijs, L. (2019). The effects of a bioresponse system on the joint attention behaviour of adults with visual and severe or profound intellectual disabilities and their affective mutuality with their caregivers. Journal of Applied Research in Intellectual Disabilities, 32(4), 890-900.

Gargiulo, R. M. (2004). Special education in contemporary society an introduction to exceptionality. Belmont: Thomson Wadsworth.

Hanzen, G., van Nispen, R. M., Vlaskamp, C., Korevaar, E. L., Waninge, A. ve van der Putten, A. A. (2020). Improving the participation of adults with visual and severe or profound intellectual disabilities: a process evaluation of a new intervention. BMC Health Services Research, 20, 1-15.

Holmqvist, E., Derbring, S. ve Wallin, S. (2017). Participation through gaze controlled computer for children with severe multiple disabilities. Studies in Health Technology and Informatics, 242, 1103-1108.

Holyfield, C., Light, J., Drager, K., McNaughton, D. ve Gormley, J. (2018). Effect of AAC partner training using video on peers' interpretation of the behaviors of presymbolic middle-schoolers with multiple disabilities. Augmentative and Alternative Communication, 34(4), 301-310.

Holyfield, C. (2019). Preliminary investigation of the effects of a prelinguistic AAC intervention on social gaze behaviors from school-age children with multiple disabilities. Augmentative and Alternative Communication, 35(4), 285-298.

Holyfield, C., Brooks, S. ve Schluterman, A. (2019). Comparative effects of high-tech visual scene displays and low-tech isolated picture symbols on engagement from students with multiple disabilities. Language, Speech, And Hearing Services in Schools, 50(4), 693-702.

Holyfield, C., Caron, J., Light, J. ve McNaughton, D. (2019). Effect of video embedded with hotspots with dynamic text on single-word recognition by children with multiple disabilities. Journal of Developmental and Physical Disabilities, 31(6), 727-740.

Hostyn, I. ve Maes, B. (2013). Interaction with a person with profound intellectual and multiple disabilities: A case study in dialogue with an experienced staff member. Journal of Intellectual and Developmental Disability, 38(3), 189-204.

Hudson, M. E., Zambone, A. ve Brickhouse, J. (2016). Teaching early numeracy skills using single switch voiceoutput devices to students with severe multiple disabilities. Journal of Developmental and Physical Disabilities, 28(1), 153-175.

Ivy, S. E., Hatton, D. D. ve Wehby, J. H. (2018). Using graduated guidance to teach spoon use to children with severe multiple disabilities including visual impairment. Research and Practice for Persons with Severe Disabilities, 43(4), 252-268. 
Janssen, M. J., N Brink-Groenendijk, C. R., Riksen-Walraven, M., Huisman, M., Van Dijk, J. P. ve Ruijssenaars. W. A. (2014). Measuring sustained interaction in adults with deafblindnessand multiple disabilities: Development of an observational coding system. British Journal of Visual Impairment, 32(2) 68-76.

Johnson, N. ve Parker, A. T. (2013). Effects of wait time when communicating with children who have sensory and additional disabilities. Journal of Visual Impairment ve Blindness, 107(5), 363.

Jongbloed-Pereboom, M., Peeters, A., Overvelde, A., Nijhuis-van der Sanden, M. W. G. ve Steenbergen, B. (2015). Learning of writing letter-like sequences in children with physical and multiple disabilities. Research in Developmental Disabilities, 36, 150-161

Kemp, C., Stephenson, J., Cooper, M. ve Hodge, K. (2016). Engaging preschool children with severe and multiple disabilities using books and iPad apps. Infants \& Young Children, 29(4), 249-266.

Knapik-Szweda, S. M. (2019, February). The significance of the process of music therapy for children with multiple social and communication disabilities. In Voices: A World Forum for Music Therapyi 19(1), 115.

Krämer, T. ve Zentel, P. (2020). Expression of emotions of people with profound intellectual and multiple disabilities. A single-case design including physiological data. Psychoeducational Assessment, Intervention and Rehabilitation, 2(1), 15-29.

Kumar, N. (2013). Early intervention of a child with multiple disabilities-a case study. Language in India, 13(2).

Lancioni, G. E., Singh, N., O'Reilly, M. F, Sigafoos, J., Boccasini, A., La Martire L., Oliva D. ve Lang, R. (2014). Orientation technology to help persons with blindness and multiple disabilities manage indoor travel and travel-related anxiety. Journal of Intellectual and Developmental Disability, 39(2), 198-205.

Lancioni G. E., Singh, N., O’Reilly, M.F., Sigafoos J., Oliva, D., Alberti, G. ve Buono, S. (2014). Persons with multiple disabilities choose among environmental stimuli using a smile response and a technologyaided program. Journal of Intellectual and Developmental Disability, 26, 183-191.

Lancioni G.E., Singh, N., O'Reilly, M. F., Sigafoos, J., Oliva, D., Campodonicoe, F., Alberti, G. ve Lang, R. (2014). Persons with multiple disabilities exercise a complex response scheme to counter incorrect head and shoulder positions via a microswitch-aided program. Journal of Intellectual and Developmental Disability, 39(4), 363-369.

Lancioni, G, E., O’Reilly, M., Singh, N., Sigafoos, J., Oliva, D., Campodonico, F. ve Lang, R. (2012). Persons with multiple disabilities exercise adaptive head and hand-eye responses using technology-aided programs: two single-case studies. Journal of Developmental ve Physical Disabilities, 24(4), 415-426.

Lancioni, G. E., Bellini, D., Oliva, D., Singh, N. N., O’reilly, M. F., Lang, R., Didden, R. ve Bosco, A. (2011). Persons with multiple disabilities select environmental stimuli through a smile response monitored via camera-based technology. Developmental Neurorehabilitation, 14(5), 267-273.

Lancioni, G. E., O'reilly, M. F., Singh, N. N., Green, V. A., Oliva, D., Campodonico, F., Lang, R. ve Buono, S. (2013). Technology-aided programs to support exercise of adaptive head responses or leg-foot and hands responses in children with multiple disabilities. Developmental Neurorehabilitation, 16(4), 237-244.

Lancioni, G. E., O'reilly, M. F., Singh, N. N., Green, V. A., Oliva, D., Buonocunto, F., Colonna, F. ve Navarro, J. (2012). Special text messaging communication systems for persons with multiple disabilities. Developmental Neurorehabilitation, 15(1), 31-38.

Lancioni, G. E., O'reilly, M., Singh, N., Sigafoos, J., Oliva, D., Alberti, G., Carella, L., Didden, R. ve Lang, R. (2013). Technology-based programs to support adaptive responding and reduce hand mouthing in two persons with multiple disabilities. Journal of Developmental and Physical Disabilities, 25(1), 65-77.

Lancioni, G. E., O'reilly, M. F., Singh, N. N., Sigafoos, J., Alberti, G., Boccasini, A., Oliva, D. ve Lang, R. (2014). Technology-aided programs to enable persons with multiple disabilities to move through sequences of occupational activities independently. Journal of Developmental and Physical Disabilities, 26(6), 703715. 
Lancioni, G. E., Singh, N. N., O'reilly, M. F., Sigafoos, J., Boccasini, A., La-Martire, M. L. ve Lang, R. (2014). Case studies of technology for adults with multiple disabilities to make telephone calls independently. Perceptual and Motor Skills, 119(1), 320-331.

Lancioni, G. E., Singh, N. N., O’reilly, M. F., Green, V. A., Oliva, D., Buonocunto, F., Sacco, V., Biancardi, E. M. ve Nuovo, S. D. (2012). Technology-based programs to support forms of leisure engagement and communication for persons with multiple disabilities: Two single-case studies. Developmental Neurorehabilitation, 15(3), 209-218.

Lancioni, G. E., Singh, N. N., O’Reilly, M. F., Green, V. A., Van der Meer, L., Alberti, G., Perilli, V., Boccasini, A., Martire, M. ve Lang, R. (2015). A speech generating device for persons with intellectual and sensorymotor disabilities. Journal of Developmental and Physical Disabilities, 27(1), 1-14.

Lancioni, G. E., Singh, N. N., O'reilly, M. F., Sigafoos, J., Belardinelli, M. O., Buonocunto, F., D’Amico, F., Navarro, J., Lanzilotti, C., Denitto, F., Tommaso, M. D. ve Megna, M. (2015). Supporting self-managed leisure engagement and communication in post-coma persons with multiple disabilities. Research in Developmental Disabilities, 38, 75-83.

Lancioni, G. E., Singh, N. N., O'Reilly, M. F., Green, V. A., Oliva, D. ve Campodonico, F. (2013). Two men with multiple disabilities carry out an assembly work activity with the support of a technology system. Developmental Neurorehabilitation, 16(5), 332-339.

Lancioni, G. E., Singh, N. N., O'Reilly, M. F., Sigafoos, J., Oliva, D., Signorino, M. ve De Tommaso, M. (2010). Helping a man with acquired brain injury and multiple disabilities manage television use via assistive technology. Clinical Case Studies, 9(4), 285-293.

Lancioni, G. E., Singh, N., O’Reilly, M. F., Sigafoos, J., Boccasini, A., Alberti, G. ve Lang, R. (2014). People with multiple disabilities use basic reminding technology to engage in daily activities at the appropriate times. Journal of Intellectual and Developmental Disability, 26(3), 347-355.

Lancioni, G. E., Singh, N. N., O’Reilly, M. F., Sigafoos, J., Alberti, G. ve Campodonico, F. (2016). Case studies of technology-aided interventions to promote hand reaching and standing or basic ambulation in persons with multiple disabilities. Perceptual and Motor Skills, 122(1), 200-219.

Lancioni, G. E., O’Reilly, M. F., Singh, N. N., Sigafoos, J., Boccasini, A., La Martire, M. L. ve Spagnuolo, C. (2016). Technology to support positive occupational engagement and communication in persons with multiple disabilities. International Journal on Disability and Human Development, 15(1), 111-116.

Lancioni, G. E., Singh, N. N., O’Reilly, M. F., Sigafoos, J., Boccasini, A., La Martire, M. L ve Smaldone, A. (2016). People with multiple disabilities use assistive technology to perform complex activities at the appropriate time. International. Journal on Disability and Human Development, 15(3), 261-266.

Lancioni, G. E., Singh, N. N., O’Reilly, M. F., Sigafoos, J., Alberti, G., Perilli, V. ve Zagaria, T. (2017). Technologyaided options for helping persons with multiple disabilities engage in communication behavior. Life Span and Disability, 20(1), 7-26.

Lancioni, G. E., Singh, N. N., O'Reilly, M. F., Sigafoos, J., Campodonico, F. ve Alberti, G. (2017). Use of a smartphone for leisure and communication by people with blindness and motor disabilities. Journal of Visual Impairment \& Blindness, 111(2), 181-186.

Lancioni, G. E., O’Reilly, M. F., Sigafoos, J., Campodonico, F., Perilli, V., Alberti, G. ve Miglino, O. (2018). A modified smartphone-based program to support leisure and communication activities in people with multiple disabilities. Advances in Neurodevelopmental Disorders, 2(3), 293-299.

Lancioni, G. E., Singh, N. N., O’Reilly, M. F., Sigafoos, J., D’Amico, F., Buonocunto, F. ve Alberti, G. (2017). Diversified occupation and communication program versions for persons with acquired neurological damage and multiple disabilities. International Journal on Disability and Human Development, 16(3), 259-265.

Lancioni, G. E., Singh, N. N., O’Reilly, M. F., Sigafoos, J., Alberti, G., Perilli, V. ve Campodonico, F. (2017). Promoting functional activity engagement in people with multiple disabilities through the use of microswitch-aided programs. Frontiers in Public Health, 5(205), 1-8. 
Lancioni, G. E., Singh, N. N., O’Reilly, M. F., Sigafoos, J., Alberti, G., Zimbaro, C. ve Chiariello, V. (2017). Using smartphones to help people with intellectual and sensory disabilities perform daily activities. Frontiers In Public Health, 5 (282), 1-8.

Lancioni, G. E., Singh, N. N., O’Reilly, M. F., Sigafoos, J., Alberti, G., Campodonico, F. ve Zimbaro, C. (2017). A technology-aided program to support basic occupational engagement and mobility in persons with multiple disabilities. Frontiers in Public Health, 5(338), 1-8.

Lancioni, G. E., Singh, N. N., O’Reilly, M. F., Sigafoos, J., Boccasini, A., Perilli, V. ve Spagnuolo, C. (2017). Persons with multiple disabilities manage positive leisure and communication engagement through a technology-aided program. International Journal of Developmental Disabilities, 63(3), 148-157.

Lancioni, G. E., Singh, N. N., O’Reilly, M. F., Sigafoos, J., Alberti, G., Perilli, V. ve Russo, R. (2018). Promoting physical activity in people with intellectual and multiple disabilities through a basic technology-aided program. Journal of Intellectual Disabilities, 22(2), 113-124.

Lancioni, G. E., Singh, N. N., O’Reilly, M. F., Sigafoos, J., Campodonico, F., Zimbaro, C. ve Zagaria, T. (2018). Helping people with multiple disabilities manage an assembly task and mobility via technologyregulated sequence cues and contingent stimulation. Life Span and Disability, 21, 143-63.

Lancioni, G. E., Singh, N. N., O’Reilly, M. F., Sigafoos, J., Campodonico, F., Oliva, D. ve D’amico, F. (2018). Using microswitch-aided programs for people with multiple disabilities to promote stimulation control and mild physical exercise. Journal of Intellectual \& Developmental Disability, 43(2), 242-250.

Lancioni, G. E., Singh, N. N., O'Reilly, M. F., Sigafoos, J., Alberti, G., Perilli, V. ve Campodonico, F. (2018). Supporting leisure and functional activity engagement in people with multiple disabilities via a technology-aided program. Technology and Disability, 29(4), 173-181.

Lancioni, G. E., Singh, N. N., O’Reilly, M. F., Sigafoos, J., Resta, E., Campodonico, F. ve Chiariello, V. (2020). Selfregulated versus staff-regulated stimulation for promoting indices of satisfaction in persons with severe/profound and multiple disabilities. Journal of Developmental and Physical Disabilities, 1-16.

Lancioni, G. E., Singh, N. N., O’Reilly, M. F., Sigafoos, J., Alberti, G., Chiariello, V. ve Carrella, L. (2020). Everyday Technology to Support Leisure and Daily Activities in People with Intellectual and Other Disabilities. Developmental Neurorehabilitation,

Mechling, L. C. ve Bishop, V. A. (2011). Assessment of computer-based preferences of students with profound multiple disabilities. The Journal of Special Education, 45(1), 15-27.

Moir, L. (2010). Evaluating the effectiveness of different environments on the learning of switching skills in children with severe and profound multiple disabilities. The British Journal of Occupational Therapy, 73(10), 446-456.

Munde, V. ve Vlaskamp, C. (2014). Initiation of activities and alertness in individuals with profound intellectual and multiple disabilities. Journal of Intellectual Disability Research, 50(3), 284-292.

Munde, V.S., Vlaskamp, C., Maes, B. ve Ruijssenaars, A. J. J., M. (2012). Catch the wave! Time-window sequential analysis of alertness stimulation in individuals with profound intellectual and multiple disabilities. Child: Care, Health and Development, 40(1), 95-105.

Nakken, H. ve Vlaskamp, C. (2007). A need for a taxonomy for profound intellectual and multiple disabilities. Journal of Policy and Practice in Intellectual Disabilities, 4(2), 83-87.

Neagu, N. ve Zsuzsanna, K. (2017). Hippotherapy as complementary method in the rehabilitation of children with multiple disabilities. Romanian Journal of Experimental Applied Psychology, 8(2), 24-36.

Nelson, C., Greenfield, R. G., Hyte, H. A. ve Shaffer, J. P. (2013). Stress, behavior, and children and youth who are deafblind. Research ve Practice for Persons with Severe Disabilities, 38(3), 139-156.

Nijs, S., Vlaskamp, C. ve Maes, B. (2018). Promoting social scaffolding behaviors in staff members and peerdirected behaviors among persons with profound intellectual and multiple disabilities: an intervention study. Journal of Policy and Practice in Intellectual Disabilities, 15(2), 124-135.

Orelove, F. P. ve Sobsey, D. R. N. (1996). Educating Children with Multpile Disabilities A Transdisciplinary Approach. Baltimore; Paul H. Brookes Publishig Co. 
Pereboom M. J., Peeters A., Overvelde, A., Nijhuis-van der Sanden, M. W.G. ve Steenbergen, B. (2015). Learning of writing letter-like sequences in children with physical and multiple disabilities. Research in Developmental Disabilities, 36, 150-16.

Pilesjö, M. ve Norén, N. (2017). Teaching communication aid use in everyday conversation. Child Language Teaching and Therapy, 33(3), 241-253.

Poppes, P., Van der Putten, A. A. ve Vlaskamp, C. (2014). Addressing challenging behavior in people with profound intellectual and multiple disabilities: analyzing the effects of daily practice. Journal of Policy and Practice in Intellectual Disabilities, 11(2), 128-136.

Poppes, P., van der Putten, A., Post, W., Frans, N., Ten Brug, A., van Es, A. ve Vlaskamp, C. (2016). Relabelling behaviour. The effects of psycho-education on the perceived severity and causes of challenging behaviour in people with profound intellectual and multiple disabilities. Journal of Intellectual Disability Research, 60(12), 1140-1152.

Ramani, K. K., Police, S. R. ve Jacob, N. (2014). Impact of low vision care on reading performance in children with multiple disabilities and visual impairment. Indian Journal of Ophthalmology, 62(2), 111.

Ricci, C., Miglino, O., Alberti, G., Perilli, V. ve Lancioni, G. E. (2017). Speech generating technology to support request responses of persons with intellectual and multiple disabilities. International Journal of Developmental Disabilities, 63(4), 238-245.

Sadler, K. M. (2019). Video self-modeling and functional behavior assessment to modify aggressive behaviors in students with autism spectrum disorder and intellectual disabilities. Education and Training in Autism and Developmental Disabilities, 54(4), 406-419.

Shih, C. H. (2011). Assisting people with multiple disabilities and minimal motor behavior to improve computer Drag-and-Drop efficiency through a mouse wheel. Research in Developmental Disabilities, 32(6), 2867-2874.

Shih, C. H. (2012). Using an Extended Dynamic Drag-and-Drop Assistive Program to assist people with multiple disabilities and minimal motor control to improve computer Drag-and-Drop ability through a mouse wheel. Research in Developmental Disabilities, 33(2), 621-629.

Shih, C. H., Cheng, H. F., Li, C. C., Shih, C. T. ve Chiang, M. S. (2010). Assisting people with developmental disabilities improve their collaborative pointing efficiency with a Multiple Cursor Automatic Pointing Assistive Program. Research in Developmental Disabilities, 31(2), 600-607.

Shih, C. H., Shih, C. T. ve Wang, S. K. (2010). Assisting people with disabilities improves their collaborative pointing efficiency with a Multiple Cursor Dynamic Pointing Assistive Program. Research in Developmental Disabilities, 31(6), 1251-1257.

Shih, C. H. (2013). Assisting people with disabilities improves their collaborative pointing efficiency through the use of the mouse scroll Wheel. Research in Developmental Disabilities, 34(1), 1-10

Shih, C. H. (2014). Assisting people with multiple disabilities to improve computer typing efficiency through a mouse wheel and on-screen keyboard software. Research in Developmental Disabilities, 35(9), 21292136.

Shogren, K. A., Kennedy, W., Dowsett, C. ve Little, T.D. (2014). Autonomy, psychological empowerment y and self-realization: exploring data on self-determination from NLTS2. Exceptional Children, 80(2), 221235.

Stasolla, F., Caffò, A. O., Perilli, V., Boccasini, A., Stella, A., Damiani, R. ve Damato, C. (2017). A microswitchbased program for promoting initial ambulation responses: An evaluation with two girls with multiple disabilities. Journal of Applied Behavior Analysis, 50(2), 345-356.

Taylor, K. ve Preece, D. (2010). Using aspects of the TEACCH structured teaching approach with students with multiple disabilities and visual impairment: Reflections on practice. British Journal of Visual Impairment, 28(3), 244-259.

Tekin-İftar, E. (2000). İleri derecede ve çoklu yetersizlikler, Eripek, S. (Ed.) Özel eğitim. (s. 81-96). Eskişehir, Anadolu Üniversitesi Yayınları. 
Trief, E., Cascella, P. W. ve Bruce, S. M. (2013). A field study of a standardized tangible symbol system for learners who are visually impaired and have multiple disabilities. Journal of Visual Impairment and Blindness, 107(3), 180-191.

Turnbull, R., Turnbull, A., Shank, M., Smith, S. ve Leal, D. (2002). Exceptional lives special education in today's school. Ohio: Merrill Prentice Hall.

Türkiye Özürlüler Araştırması İkincil Analiz (2002). http://www.ozida.gov.tr/arastirma/troailerianaliz.htm adresinden erişilmiştir.

Walsh, D. ve Downe, S. (2005). Meta-synthesis method for qualitative research: a literature review. Journal of Advanced Nursing, 50(2), 204-211.

Wei, X., Blackorby, J. ve Schiller, E. (2011). Growth in reading achievement of students with disabilities, ages 7 to 17. Exceptional Children, 78(1), 89-106.

Wessels, M. D., Bossink, L. W. ve van der Putten, A. A. (2017). The effects of a power-assisted exercise intervention on alertness in people with profound intellectual and multiple disabilities. Journal of Cognitive Education and Psychology, 16(3), 281-292. 
"Çoklu Yetersizliğe İlişkin Uluslararası Çalışmaların Gözden Geçirilmesi” başlıklı çalışmanın yazım sürecinde bilimsel, etik ve alıntı kurallarına uyulmuş; toplanan veriler üzerinde herhangi bir tahrifat yapılmamış, karşılaşllacak tüm etik ihlallerde "Sakarya University Journal of Education Dergisi ve Editörünün" hiçbir sorumluluğunun olmadığı, tüm sorumluluğun yazarlara ait olduğu ve çalışmanın herhangi başka bir akademik yayın ortamına değerlendirme için gönderilmemiş olduğu bu çalışmanın yazarları tarafından taahhüt edilmiştir. 